\title{
Understanding Chinese jade in a world context
}

\author{
Elsley Zeitlyn Lecture on Chinese Archaeology and Culture \\ read 2 February 2017
}

\section{GINA L. BARNES \\ SOAS, University of London}

\begin{abstract}
For millennia, jade has been valued in many cultures in Chinese archaeology. The favoured types and sources of jade have changed over time, as has our knowledge of the stones themselves. One of the greatest problems in dealing with archaeological jades is the correct identification of the stones in order to trace their source and thereby understand the social relations underlying their patterns of procurement, production, and consumption. This paper examines the problems of identification and sourcing of Chinese archaeological jades from a worldwide point of view, dissecting terminological problems arising from mineralogy and rock geochemistry, and explicitly identifying the geological constraints on the formation of nephrite and jadeite. In particular, the role of plate tectonics in determining the occurrence of jade provides an overarching perspective on where in China jade sources might occur and how nephrite might be mined and distributed, together with its associated rocks and minerals. The latter associations are equally important to this jade sourcing endeavour.
\end{abstract}

Keywords: jade, geochemistry, mineralogy, plate tectonics, nephrite, jadeite, Chinese archaeology

\section{INTRODUCTION}

The first problem encountered in discussing 'jade' is defining what we mean by this term. It is commonly used to translate the Chinese word $y u$ (玉), traditionally designating 'beautiful stones' worthy of fashioning into ritual objects and personal ornaments. The most highly prized stones have been scientifically identified as either the rock called 'nephrite', obtainable in China, or the mineral 'jadeite', which was imported into China after 1784 from Burma (Myanmar). However, a whole series of other kinds of rocks and minerals have come under the jade/yu umbrella through time, so that these words do not designate a specific kind of stone but more a 'valuable 
stone'. In this paper, 'jade' is used in its umbrella function, while nephrite and jadeite are designated 'true jades'. ${ }^{1}$ The mineralogy of these will be discussed at length below, but it would be a mistake to dismiss the myriad types of rocks and minerals referenced by other terms such as 'false jades', 'hemi-jades', 'pseudo-jades', and jade imitations. Many such ornamental stones are included as jade/ $y u$, and they often occur together with true jades in their geological setting. Thus, all of these false and true jades need to be dealt with together to understand their procurement, processing, and distribution.

This paper is only a first step in reaching that goal. It is divided into four parts: first, discussing the mineralogy of true jades and how they occur in the archaeological record; second, looking at the mainly metamorphic processes necessary for nephrite formation; third, pulling back to examine the large-scale tectonic processes that determine where nephrite will form; and finally, offering specific case studies of known nephrite and other jade sources in China together with mineralogical analyses of raw materials and artefacts. The remainder of this introduction will provide a necessarily brief overview of jade in East Asia now and then.

\section{Jade generally in East Asia}

In 2010, the highly valued 'mutton fat' jade (yangzhiyu羊脂玉) was selling for more than gold, at US $\$ 3,000$ per ounce. ${ }^{2}$ This put new pressures on the source of this milky white true jade in China's western Xinjiang province, where raw jade cobbles have been traditionally collected from the appropriately named White Jade River and Black Jade River - translations of Yurungkash and Karakash, respectively, in the local Uyghur language. The Hetian area (aka Yutian, Khotan), located along one branch of the Silk Road in western China, is the major historical source for a variety of jades, utilised in the Shang through Han periods (2nd millennium BC into the 1st millennium $\mathrm{AD})$ and then again from the mid-18th century, when actual mining of jade in the mountains began. ${ }^{3}$ Between the Tang and Qing Dynasties (8th to 19th centuries), Manas jade from northern Xinjiang province was dominant. ${ }^{4}$

However, Hetian is only one among several sources of nephrite, the most common form of true jade. Jades from these sources were joined in late-19th-century China by Canadian nephrite; sources of nephrite in British Columbia were first discovered by Chinese gold rush miners in the 1850s, and some of the top-quality materials sent to

\footnotetext{
${ }^{1}$ Keverne (1995), Middleton \& Ambers (2005: 403). Thus, it is important not to assume that jade $=$ 'true jade'.

${ }^{2}$ Jacobs (2010).

${ }^{3} \operatorname{Lin}(2007)$.

${ }^{4}$ Manas Uyghur spelling = Manasi Chinese spelling. Wang S. (2011: Table 3).
} 
China were incorporated into the imperial collections. ${ }^{5}$ British Columbia is now the top producer of nephrite in the world. ${ }^{6}$ Importation of white and green nephrite from the Eastern Sayan Mountains of Siberia into China began in 2005; because these deposits are similar to those of Hetian, some of the Sayan white jade is valued as highly as local 'mutton fat' jade. ' Sayan jade was originally traded in through Heilongjiang province in the far northeast - at the opposite end of the country from Hetian - facilitated between China and Russia by the Nerchinsk Treaty of 1689. There is a tendency now to refer to any white mutton fat nephrite as Hetian jade, regardless of where it is from. ${ }^{8}$ Turning to Taiwan, Fengtian has always produced a considerable amount of nephrite, most of which was traded to the south and supplied Southeast Asia rather than Mainland China with precious stones. ${ }^{9}$ However, demand was such that post-war Taiwan imported much British Columbian nephrite - until the PRC (People's Republic of China) markets opened up in 1986 and claimed most of the Canadian exports. ${ }^{10}$

The rarer form of the jade mineral, jadeite, was known in Japan as early as the 6th millennium BC among Jomon-period forager-horticulturalists, ${ }^{11}$ The major sources are the Ōmi and Kotaki Rivers, in Itoigawa City, Niigata Prefecture, which carry jade cobbles to the edge of the Japan Sea where they could be collected in the rivers and on the 'Jade Coast' - much like the riverbeds of Hetian. Itoigawa jade again became popular in the Late Yayoi through Kofun periods of state formation between the 3rd and 6th centuries AD. The jadeite curved bead became one of the three imperial insignias of the Japanese emperor, along with the bronze mirror and sword - still playing a role in modern accession ceremonies. Similar curved beads were popular in the Bronze Age of the Korean Peninsula, though most were made of amazonite. However, rulers of the Silla Kingdom in the 6th century AD procured Itoigawa jade from the Japanese Islands for curved-bead pendants on their gold crowns. Interestingly, Japanese jadeite was never exported farther west than the Korean Peninsula, and China had to wait until the 18th century to obtain a supply from Burma.

Burmese jade was discovered in the 13th century, and some trickled into China, but it was commercially imported only after $1784 .^{12}$ The Uyu (Uru) and Iwa River valleys and particularly Hpakan village form the centre of the Jade Tract, where jade

\footnotetext{
${ }^{5} \mathrm{Hsu}$ et al. (2015).

${ }^{6}$ Iizuka (2012).

${ }^{7}$ Hsu et al. (2015).

${ }^{8}$ Anon (2006).

${ }^{9}$ Hung (2006, 2007).

${ }^{10} \mathrm{Hsu}$ et al. (2015).

${ }^{11}$ Bausch (2003).

${ }^{12}$ Hughes et al. (2000).
} 
cobbles are dug out from alluvial gravels or conglomerate, or quarried from jade dikes in serpentinite. ${ }^{13}$ In particular, the high-chromium content jadeite that polished to 'kingfisher' translucence was a palace favourite in China and was accordingly often referred to as 'imperial jade'.

Thus, although two sources of jadeite existed near the China Mainland, neither was utilised in the prehistoric or early historic periods of China. One of the most prolific sources of nephrite, on Taiwan, despite supplying jade to Pacific Southeast Asia, ${ }^{14}$ was seldom if ever a source for elite consumption on the China Mainland. The preferential selection and use of different kinds of jade were obviously conditioned by communication and transport networks, so that favoured types grew out of established patterns of interaction rather than exploratory searches for new sources. Even in modern times, the Chinese have been reluctant to import jades from new untried sources (as experienced by the Jade West Group in British Columbia). ${ }^{15}$

\section{Jades in prehistoric and early dynastic cultures of China}

In early state societies on the Korean Peninsula and Japanese Islands, jadeite curved beads served as symbols of status and authority. On the China Mainland, however, nephrite became imbued with far greater social and cosmological significance. Jade objects were valued in China for several reasons: to symbolise rank, power, morality, wealth, and immortality. In the 2nd century BC, Xu Shen ${ }^{16}$ wrote of the five virtues of jade in the Shuo Wen: its lustre symbolised 'charity', its sound 'wisdom', its hardness 'courage', its smoothness 'equity', and its translucence 'rectitude'. ${ }^{17}$ The physical nature of the jades in part contributed to their valuation, such as hardness, toughness, colour, and feel. Enormous amounts have been written on the roles of jade in Chinese society and the attributes for which it was valued..$^{18}$ Drawing on these works, only a selective view will be offered below to establish the chronological succession, though the generalisations belie tremendous variability in jade presence and use.

\section{Neolithic China}

In the Neolithic periods of the China Mainland, nephrite was initially used to make slit-earrings in the Xinglongwa (Chahai) culture of the northeast $c a .6000 \mathrm{BC}$; the succeeding Hongshan culture (4500-2800 BC) used jade to fashion a variety of shapes,

\footnotetext{
${ }^{13}$ Hughes et al. (2000).

${ }^{14}$ Hung et al. (2007).

${ }^{15}$ Hsu et al. (2015).

${ }^{16}$ East Asian names are given surname first, as traditional in those cultures.

${ }^{17}$ Translations of virtue wordings from Wen \& Jing (1992).

${ }^{18}$ For example, Rawson (1995).
} 
some understandable by analogy (eagles, turtles) and others entirely mysterious (flared cylinders or 'cloud' shapes). These early jades are characterised by specific jadeworking techniques: string cutting with abrasives (using bamboo or leather strips or fibre cords) to cut slabs or notches; pieces of wood or bamboo plus abrasives to shape and polish; and edge bevelling. ${ }^{19}$ Because nephrite was more difficult to work than other silicate stones (which could be chipped then polished), the greater length of time spent in fashioning this into specific shapes made it more valuable. By Hongshan times, burials with jades are interpreted as the graves of emerging elites, and many of the objects are thought to be personal ornaments worn on the body or on clothing. ${ }^{20}$ The burial context combined with the shape variety implies that the jades functioned as status markers and perhaps totems. ${ }^{21}$

The second great Neolithic jade culture to arise, overlapping with Hongshan, was Liangzhu (3300-2000 вс) in the Hangzhou Bay region. Jade-working began in the Beiyinyangying culture in Jiangsu province and then spread to south of Lake Tai at the emergence of the Liangzhu culture. ${ }^{22}$ Liangzhu jades characteristically take the shape of squared tubes with round bores (cong), flat perforated discs (bi), and flat axe shapes (yue); these are accompanied by a variety of small jades and beads. Jades were buried, often in great numbers, in graves of the elite, and there is some indication they were used in symbolic ranking of individuals. ${ }^{23}$ The juxtaposition of square and circle in cong composition has often been anachronistically interpreted as the square earth and circular heaven motifs common in later Chinese thought. But since Liangzhu people left no documents recording their thinking, it is probably prudent to view these items as important ritual items and status markers in the increasingly hierarchical Late Neolithic without these cosmological overlays. ${ }^{24}$

Several other regional Late Neolithic cultures made use of numerous 'jade' objects - especially for ceremonial blades - and human forms came to be depicted in nephrite. ${ }^{25}$ In the 2nd millennium BC, ceremonial jades in the Sanxingdui culture of modern Sichuan province were deposited in non-funerary ritual contexts. ${ }^{26}$ However, in the Shang (1500-1046 BC) and Early Zhou (1046-221 вC) cultures, the Neolithic tradition of grave goods continued, with blades, particularly of halberd shape, and animal shapes becoming the main burial jades. In the Shang period, there began a

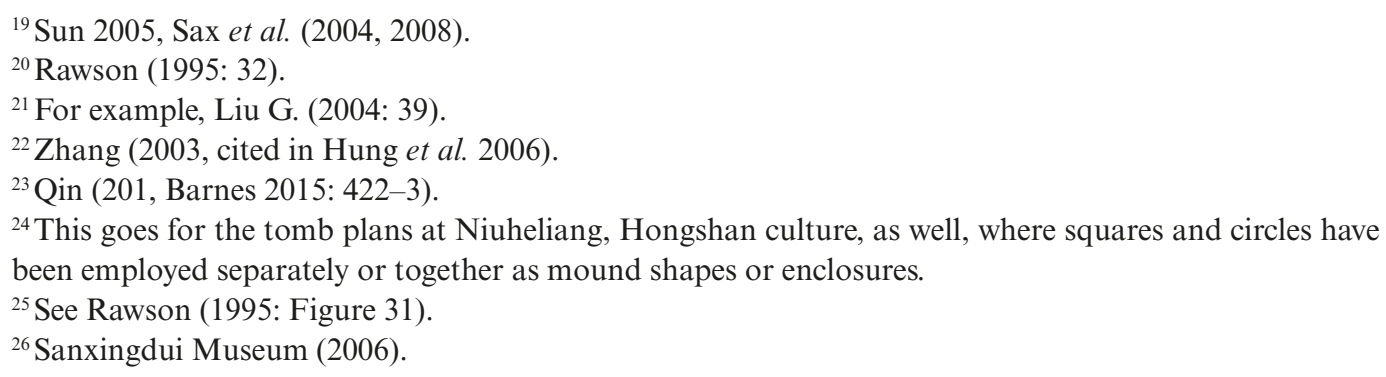


tradition of including heirloom objects along with newly fashioned, often exotic, pieces from other regions among the grave goods; some of these stimulated new creations while others were reworked or re-used in new artefactual constructions, indicating their treasured status. ${ }^{27}$ Indeed, the prevalence of simplistic animal shapes in Shang has been attributed to influence from local cultures. ${ }^{28}$

\section{Early dynastic China}

Shang-style jades continued into the Early (Western) Zhou period but apparently without much enthusiasm or investment, ${ }^{29}$ judging by their simple shapes and decoration. However, from the 9th century BC new forms and motifs appeared, some influenced by surrounding cultures. Incised surface decoration of composite and interlaced figures, particularly humans, birds, and dragons, became ubiquitous. Plaques, arcs, and beads were combined into elaborate pendants and masks worn by deceased aristocrats in their graves. Rawson speculates that these jades may have had some protective power beyond signifying rank, giving rise to the later jade suits. ${ }^{30}$ Inscriptions on bronze vessels inform us that jades signifying rank were initially granted by a king to a noble, but as time passed, they were exchanged among nobles often as payments in kind. ${ }^{31}$

Eastern Zhou and Han witnessed the decline of some jade shapes and the resurgence of others: discs, rings, various blades, and arcs. The problematic Zhou Li text divides jades into ceremonial and ritual functions, but these do not seem to correspond to real assemblages. Numerous jades have been discovered archaeologically in ritual deposits, but if 'ceremonial' refers to jades used in ephemeral ceremonies and living displays, their roles are more difficult to assess archaeologically. Jades excavated from burials, including jade suits, continued their ornamental rank and status functions, but small-size or stone substitutes began to appear as well. Surface decoration of jades became heavily influenced by gold-working coming in from Central Asia, particularly the development of relief carving in addition to incising. Representational figures were replaced by abstract patterns 'that reflected the light and made the jades gleam. ${ }^{32}$ These latter foreign influences included belt and weapon fittings that were then reproduced in jade.

Rawson provides an illuminating explanation of the sudden decline of jade burial goods in Late Han, citing the rise of religious Daoism and the potential for an afterlife outside the tomb - in paradise. Jades were no longer necessary to protect and

\footnotetext{
${ }^{27}$ Rawson (1995: 23-8).

${ }^{28}$ Rawson (1995: 43).

${ }^{29}$ This section is summarised from Rawson (1995: 45-53).

${ }^{30}$ Rawson (1995: 50).

${ }^{31}$ Rawson (1995: 52-3).

${ }^{32}$ Rawson (1995: 245).
} 
serve the deceased for continued life within the tomb, and jade objects might even have been ground up for consumption following Daoist recipes. ${ }^{33}$

This brings to a close a brief account of jade use in early China, hardly doing justice to the rich variability across space and time. We now turn to the focus of this paper: jade definitions, compositions, formation, and sources.

\section{PART ONE: MINERALS AND ROCKS}

As mentioned above, many different kinds of rocks and minerals are included under the umbrella terms jade/ $y u$. What is the difference between a rock and a mineral? This is not such an idle question when dealing with jade, as misunderstandings begin here. Rocks are made of minerals, and minerals are composed of elements. The first section below compares the two types of true jades in terms of rock and mineral identity and characteristics; then we look at the archaeological occurrence of Chinese nephrite as well as other ornamental stones in prehistoric archaeological sites, ending with an introduction to non-nephrite rocks and minerals. The second section of Part One is devoted to a closer examination of nephrite in terms of its chemical composition, necessitating an excursion into the solid-solution chemistry of the constituent minerals. By the end of Part One, it should be fairly clear how we use the concept of jade in art and archaeological studies, and the review of true-jade chemistry will have informed us of important changes in mineralogical definitions and progress in compositional analysis since early work in this area.

\section{Myriad meanings of 'jade'}

\section{Two types of true jade}

Researchers often state that there are two types of true jade: nephrite and jadeite, but these are not equivalent. The word 'nephrite' refers to a rock with the constituent minerals tremolite and/or actinolite and a specific fabric. Jadeite is a mineral that is a major constituent of the rock 'jadeitite'. Thus, to be accurate, we should use the words nephrite and jadeitite as equivalent rock terms for 'true jades'; these rocks contain other minerals and elements that are not represented in the ideal formulae of the jade minerals, ${ }^{34}$ and indeed, there is another category, 'hemi-jade', that refers to mixtures of jade minerals with other minerals to the extent that the rock is no longer considered nephrite or jadeitite. Details are forthcoming below.

\footnotetext{
${ }^{33}$ Rawson (1995: 79).

34 'Ideal' in the sense of conforming to the simple chemical formula without many minor elements.
} 
Table 1. Comparisons of the two 'true jades'.

\begin{tabular}{lll}
\hline Rock & Nephrite & Jadeitite \\
\hline Essential minerals & tremolite, actinolite & jadeite \\
Crystal habit & fibrous & non-fibrous \\
Texture & silky & blocky \\
Other properties & tougher than jadeitite & harder than nephrite \\
Mineral group & Calcium amphibole & Sodic pyroxene \\
Crystal structure & double-chain inosilicate & single-chain inosilicate \\
Composition & $\mathrm{Ca}_{2}\left(\mathrm{Mg}, \mathrm{Fe}_{5} \mathrm{Si}_{8} \mathrm{O}_{22}(\mathrm{OH})_{2}\right.$ & NaAlSi $\mathrm{O}_{6}$ \\
Water content & hydrous & anhydrous \\
Density & $2.9-3.01 \mathrm{~g} / \mathrm{cm}^{3}$ & $3.3-3.6 \mathrm{~g} / \mathrm{cm}^{3}$ \\
Hardness (Mohs scale) & $6-6.5$ & $6-7$ \\
\hline
\end{tabular}

Sources: compiled from Deer et al. (1997a, 1997b), Harlow et al. (2014), Desautels (1986).

Nephrite and jadeitite are both silicate rocks (containing $\mathrm{SiO}_{2}$ ), but their chemical compositions and constituent minerals are very different, as shown in Table 1: nephrite contains substantial amounts of calcium amphibole and hence has large amounts of calcium-Ca and substantial but variable amounts of magnesium-Mg and iron-Fe, whereas jadeitite contains jadeite and hence has large amounts of aluminium-Al and sodium-Na. The chemical formulae given here for these minerals are idealised and do not include minor and trace elements that can determine colour; similarly, the constituent minerals of nephrite and jadeitite do not include constituent minor and trace minerals.

The two rocks also have very different fabric. Nephrite has a silky feel, and its matted, fibrous (often called 'felted') nature - the interlocking of short fibres - makes it tough, i.e., difficult to break. Felting is produced in two stages: first is the crystallisation of the minerals, followed by mechanical processes which twist or intertwine the crystals under relatively high temperature $\left(400-500^{\circ} \mathrm{C}\right)$ but low pressure. ${ }^{35}$ The crystals may be oriented in random, radial, or unidirectional patterns, each producing a specific nephritic 'material'. Tremolite/actinolite without felting is not nephrite. Jadeite is harder than amphibole, indicated by its Mohs hardness, ${ }^{36}$ but jadeitite usually has interlocking fan-shaped or blocky crystals rather than the fibrous structure that is typical of nephrite.

The greatest difference between true jades and other rocks and minerals, however, is not their appearance - as there are many beautiful stones - but the difficulty of working true jades. Not just because they are hard - quartz is even harder at

\footnotetext{
${ }^{35}$ Campbell et al. (2008).

${ }^{36}$ On the hardness scale developed by Frederick Mohs in 1822 see Minsocam (2016).
} 
Mohs 7-but because they cannot easily be formed by chipping and require specific time-consuming and laborious fashioning by abrasion. ${ }^{37}$ This investment increases their value proportionally; through time, this added value could only be afforded by the elite.

In China, nephrite implements are known from the Late Palaeolithic, ${ }^{38}$ but by Neolithic times, nephrite ornaments were dominant, though the types and quantities of non-nephrite ornaments vary with time-period and region. Nevertheless, possession of true jades correlates with differentiation of social status through time, the ultimate status symbol in recent history being feicui 翡翠 (emerald green) 'imperial jade' from Burma. However, since Burmese jadeitites from Myanmar were imported too late to have an impact on archaeological assemblages, and because Japanese jadeitites from Itoigawa were never imported into China, any further mention of jadeitite will be in the manner of comparative material.

\section{Archaeological 'jades'}

As early as 1989, Wen Guang, of the Geological Research Institute in Beijing, lamented that the traditional Chinese word for jade ( $y u$ 玉), originally confined to tremolite, had been broadened to the extent that it was meaningless. ${ }^{39} \mathrm{We}$ can also say the same for the English term 'jade', as it may refer to several ornamental stones. From the late 1980s to early 1990s, Wen Guang and Jing Zhichun singly and together published a series of geoarchaeological articles on jade compositions. This body of work serves as the springboard for the present study. Wen and Jing emphasised that the identity of the stone cannot be made precisely without investigation of its chemical composition and microstructure. Their 1992 article analysed the compositions of 268 archaeological jades from Chinese Neolithic sites, summarised in Table $2 .^{40}$ They found that stones included as jade $(y u)$ in the Neolithic archaeological reports consisted of 21 different rocks and/or minerals in addition to true jade (nephrite).

Wen and Jing concluded from these data that true jade was dominant in the Neolithic samples: 204 of 268 pieces (76 per cent as calculated here). Due to this dominance, they proposed that Early Neolithic peoples in northeastern China (from Xinle and Chahai sites, now included in the Xinglongwa culture), were already able to distinguish true jade from other stones, as their ornaments are 100 per cent nephrite. ${ }^{41}$ However, the breakdown of some of the site contents showed that among the

\footnotetext{
${ }^{37}$ Sax et al. $(2004,2008)$.

${ }^{38} \mathrm{Fu}$ (2003), Tang C. (2008).

${ }^{39}$ Wen (1989).

${ }^{40}$ Wen \& Jing (1992).

${ }^{41}$ Though recently other ornamental stones, chalcedony and talc, have been reported from Xinlongwa culture sites in this area (Tang C. 2008: 265).
} 
Table 2. Collation of Neolithic 'jade' artefacts by culture, period, and geography. Percentages indicate what 'kinds' of jade were found at various Neolithic sites.

\begin{tabular}{|c|c|c|c|c|c|c|c|c|c|}
\hline \multirow{2}{*}{$\begin{array}{l}\text { Years BC } \\
>6000\end{array}$} & \multirow{2}{*}{$\begin{array}{l}\text { Northeast cultures } \\
\text { Chahai } \\
\text { (Xinglongwa) }\end{array}$} & \multirow[t]{2}{*}{$\begin{array}{l}\text { East coast and } \\
\text { inland cultures }\end{array}$} & \multicolumn{2}{|c|}{$\begin{array}{l}\text { True jade } \\
\text { (nephrite) }\end{array}$} & \multicolumn{2}{|c|}{ Hemi-jade } & \multicolumn{2}{|c|}{ Pseudo-jade } & \multirow{2}{*}{$\begin{array}{l}\text { Total } \\
8\end{array}$} \\
\hline & & & 8 & $100 \%$ & & & & & \\
\hline \multirow[t]{4}{*}{$>4000$} & & Hemudu & & & & & 5 & $100 \%$ & 5 \\
\hline & & Majiabang & & & & & 7 & $100 \%$ & 7 \\
\hline & & Beixin & & & & & 2 & $100 \%$ & 2 \\
\hline & Xinle & & 15 & $100 \%$ & & & & & 15 \\
\hline \multirow[t]{2}{*}{$>3000$} & Hongshan & & 40 & $69 \%$ & 2 & $3 \%$ & 16 & $28 \%$ & 58 \\
\hline & & Songze & 8 & $89 \%$ & & & 1 & $11 \%$ & 9 \\
\hline \multirow[t]{4}{*}{$>2000$} & & Liangzhu & 102 & $86 \%$ & 1 & $<1 \%$ & 15 & $13 \%$ & 118 \\
\hline & & Dawenkou & 1 & $100 \%$ & & & & & 1 \\
\hline & Post-Hongshan & & 5 & $56 \%$ & & & 4 & $44 \%$ & 9 \\
\hline & & Longshan & 25 & $69 \%$ & 4 & $11 \%$ & 7 & $19 \%$ & 36 \\
\hline Totals & & & 204 & $76 \%$ & 7 & $3 \%$ & 57 & $21 \%$ & 268 \\
\hline
\end{tabular}

Source: Based on Wen \& Jing (1992: Table 1).

149 nephrite samples, 128 (86 per cent) were tremolite, 16 (11 per cent) were actinolite, and 5 were tremolite-actinolite. In a second study of 500 nephrite artefacts, ${ }^{42}$ percentages of tremolite alone varied upward from 65 per cent, the remainder being actinolite.

Non-nephrite 'false jades', 'hemi-jades', and 'semi-nephrite'

Wen and Jing further distinguished two kinds of non-nephrite stones used as substitutes for true jades in later cultures, as noted in Table 2: 'hemi-jades' and 'pseudo-jades':

Pseudo-jades, they said, 'may be found associated with nephrite in natural deposits, which might cause ancient people to treat these jade-like minerals as nephrite' ${ }^{43}$ The five most common were antigorite, sericite, quartz, talc, and calcite; ${ }^{44}$ others named were albite, amazonite, dickite, diaspore, enstatite, fluorite, kaolinite, lizardite, magnesite, muscovite, and pyrophyllite. ${ }^{45}$

Hemi-jade is a term they introduced 'to refer to the mixture of nephrite and associated minerals'. Such associated minerals in hemi-jades are yet again different from 'auxiliary minerals (impurities) such as magnetite and chromite', which often give jades their varying colours. ${ }^{46}$ Hemi-jades included albite + tremolite, calcite +

${ }^{42}$ Wen \& Jing (1996).

${ }^{43}$ Wen \& Jing (1992: 258).

${ }^{44}$ Wen \& Jing (1996: 67).

${ }^{45}$ Wen \& Jing (1992).

${ }^{46}$ Wen \& Jing (1992: 255). 
tremolite, talc + tremolite, antigorite + tremolite, amazonite + tremolite, and tremolite + prehnite. ${ }^{47}$ The common theme here is 'tremolite', which is the dominant mineral in the sample of archaeological jades analysed by Wen and Jing.

Another term, 'semi-nephrite', has occasionally been used in the past for nephrites that span the tremolite/actinolite border; ${ }^{48}$ but that term now denotes 'either massive amphibole, which lacks the felted cohesive texture, or nephritic amphibole enclosing coarser crystals' ${ }^{49}$ In other words, 'semi-nephrite' has the same chemical composition as tremolite-actinolite but not the felted texture.

These early results can be contrasted with recent studies, reviewed by Wang Rong in $2011 .{ }^{50}$ Wang openly acknowledges that ancient jades in China include many 'types' of jade: amphibole jade (i.e., nephrite, including both tremolite and actinolite), serpentine jade, turquoise jade, agate jade, anorthite jade, zoisite jade, and others. ${ }^{51}$ His study covers a wider range of time periods and geographical areas, from the Neolithic to the Han period (206 BC-AD 220) across northern and eastern China. Of note are the artefacts made of serpentine and agate in collections from early Neolithic sites on the East Coast, with nephrite varying from 29 per cent to 54 per cent. Thus, it is clear that nephrite did not dominate in all Mainland Neolithic cultures. In the succeeding Liangzhu culture, nephrite rose to 93 per cent, but in the later periods and peripheral regions, nephrite decreased to between 66 per cent and 73 per cent..$^{52}$ These figures were culled from the existing literature and so might change with rigorous sampling.

Examining the ornamental stones considered by archaeologists to be jades $(y u)$, Wen and Jing count 20 different rocks and minerals, ${ }^{53}$ whereas Wang counts over 30. This corresponds to other situations around the world. New Zealand greenstones, treasured by the Maori, include nephrite (роипати) and bowenite (a hard variety of antigorite) called tangiwai. ${ }^{54}$ In China, Soochow (Suzhou) jade is bowenite ${ }^{55}$ it has been carved to make some of the most exquisite jade sculptures in historical and contemporary China. Two of the most common jade types today, Lantian jade and Xiuyan jade, are primarily the serpentine mineral antigorite, ${ }^{56}$ while lizardite, another

\footnotetext{
${ }^{47}$ Wen \& Jing (1992, 1996: 64).

${ }^{48}$ Iizuka (2012).

${ }^{49}$ Harlow \& Sorenson (2005: 120, 125).

${ }^{50}$ See Table $2 \mathrm{~A}$ online at https://docs.google.com/document/d/12zlX8d5eg6LVAFn575jP3MqFDbKJ1 AYdJkjXL1exAEQ/edit

${ }^{51}$ Wang, R. (2011: 674).

${ }^{52}$ Numbers of artefacts were reported; the percentages are my calculations.

${ }^{53}$ Wen \& Jing (1996: 67), Wang, R. (2011).

${ }^{54}$ Tennant et al. (2005).

${ }^{55}$ Desautels (1986: 9).

${ }^{56}$ Wang Y. et al. (2012) (but they note this might not apply to ancient Lantian jade); Liu Z. et al. (2009), Liang et al. (2012).
} 
serpentine mineral, has recently been identified for the first time in Lantian jade. ${ }^{57}$ Some modern Lantian jade is also made of serpentinised marble, and a similar deposit was discovered in 2013 at Pizhou City, Jiangsu Province. This is now being called 'Lantian jade' even though it is not from Lantian County. These non-nephrites are different from Lantian tremolite jade, to be discussed below. Jingbai jade is actually white agate, ${ }^{58}$ and Dushan jade (Nanyang jade) is an aggregate of plagioclase, zoisite and hornblende).$^{59}$ These identities in themselves do not totally devalue these materials: Cheng et al. state that stones other than nephrite 'such as serpentine, Dushan jade, Jingbai jade, even quartz, were also artistically valued' ${ }^{60}$ while Wang and Li state that 'the five most important materials of Chinese ancient jade are amphibole, serpentine, turquoise, agate/chalcedony, and anorthite-zoisite (Dushan jade). ${ }^{61}$ Wang and Zhang list amphibole, serpentine, turquoise, and quartz varieties as the four main materials of ancient Chinese jade. ${ }^{62}$

Many minerals and rocks are currently marketed as jade: both Amazon jade and Colorado jade are amazonite (microcline); others are Andes jade and Korean jade (serpentine), Australian jade (chrysoprase), Californite (massive vesuvianite); Guatamalan jade negro (omphacite-taramite), Indian and Mixian jade (aventurine quartz), Korean jade (bowenite), Lushan Mountain jade (marble), Malaysian jade (quartz), Mexican and Shaanxi Moyu jade (calcite), New Caledonian jade (anorthite), Ophite or New jade (serpentine), Oregon or Swiss jade (green chalcedony), Pounamu (New Zealand greenstones), Rainbow jade jade lila (jadeite-pumpellyite rock), Shetaicui jade (aventurine/dolomite/quartzite), Tangiwai (bowenite), Transvaal jade (green hydrogrossular garnet), Xiuyu jade (serpentine), prehnite, grossular garnet, agate, jasper, serpentinite, albitite, meta-basite, quartz schist ... the list could go on. In contrast to Wen and Jing's term 'pseudo-jade', these have also been called 'false jades' or 'imitation jades', in addition to modern plastic and glass varieties termed 'jade simulants' ${ }^{63}$

The lesson learned is that much of what is termed jade is not true jade. If it is artistically pleasing, then it has value. But if we want to know the sourcing and distribution of jades in ancient times - or if we want to be sure that a gem dealer is not

\footnotetext{
${ }^{57}$ Wang Y. et al. (2012).

${ }^{58}$ Cheng et al. (2004: 31, Table 1).

${ }^{59}$ Xiao Q. et al. (2009), Wang R. \& Li (2011), Zhang G. et al. (1989); sometimes called the rock 'saussurite' (Wen \& Jing 1996).

${ }^{60}$ Cheng et al. (2004).

${ }^{61}$ Wang R. \& Li (2011: abstract).

${ }^{62}$ Wang R. \& Zhang (2010).

${ }^{63}$ For an interestingly long list, see Desautels (1986: Chapter 2), Walker (1991), Middleton \& Freestone (1995), Gems \& Gemology (1980-2010 index), Dept of Geological Sciences (2009). See http://madcatwomanenterprises.tumblr.com/post/74776783593/jade-as-there-are-a-very-large-variety-of.
} 
overcharging us! - then it is incumbent upon us to know what kind of rock or mineral we are dealing with. The terms 'pseudo-jade', 'false jade', and 'imitations' are negative in nature and likely to invite dismissal of these other rocks and minerals, but in fact, these materials can be extremely illuminating as to source areas and mining technologies. Many were exquisitely worked and included as $y u$. For two reasons, they should be considered together with variations in quality of the true jades: (1) they will inform on sources of raw materials, and (2) their relative distributions can be used to monitor the development of hierarchical social relations and trade routes in the archaeological record.

\section{The problem with nephrite}

Nephrite: rock and minerals

Minerals and mineral names are approved by the Commission on New Minerals, Nomenclature and Classification of the IMA (International Mineralogical Association). The IMA only approves names for valid mineral species, ${ }^{64}$ not rocks, but it can redefine existing minerals and declassify those previously accepted but now discredited on chemical or crystallographic grounds. IMA approval of a mineral name is a recommendation that is followed by most publishers, and ideally, an unapproved name would be tagged in quotation marks. Some of these latter examples might include minerals still undergoing scientific examination. Varieties of minerals (i.e. sub-species or non-species) are not dealt with by the IMA, though many discredited minerals enter the realm of varieties.

'Nephrite' was once considered a mineral but was subsequently discredited as a valid mineral species; ${ }^{65}$ nevertheless, it is often used as a synonym of the mineral tremolite - in the sense that mica is a synonym or common name for a muscovite mineral and rock salt is a synonym or common name for the mineral halite. ${ }^{66}$ However, as we shall see below, nephrite is not a mineral at all: it is a rock.

Researchers in the field describe nephrite in terms of the tremolite-actinolite series. ${ }^{67}$ The 'series' here refers to solid-solution chemistry, where a mineral or minerals have a range of chemical compositions compatible with their crystal structure. The assignment of nephrite to a tremolite-actinolite series implies that actinolite is an end-member of the series, which is a mistake. ${ }^{68}$ Actinolite is actually the middle

\footnotetext{
${ }^{64} 5291$ minerals as of September 2017 (IMA-CMNNM 2017b).

${ }^{65}$ Nickel \& Nichols (2004).

${ }^{6}$ Nickel \& Nichols (1991: Appendix C "Synonymy of nonspecies names").

${ }^{67}$ Wen \& Jing (1992: 261), Wen (1994), Tsien (1996), Wen \& Jing (1996), Harlow \& Sorensen (2005).

${ }^{68}$ Iizuka et al. (2007: 14, "actinolite, the iron-rich end-member of the calcium amphiboles"). Furthermore, there are other calc-amphibole solid-solution series: e.g., with anthophyllite and cummingtonite-grunerite as end-members (Wittke 2009).
} 
member of the series 'tremolite-actinolite-ferro-actinolite'; this series has since been renamed 'tremolite-ferro-actinolite', a new designation whereby only the endmembers of the solid solution are given in binary nomenclature. ${ }^{69}$ Consequently, Harlow et al. revised their definition of nephrite as 'a rock composed fundamentally of tremolite-ferro-actinolite'. ${ }^{70}$ This properly specifies the series, but it obscures the fact that there are currently no known nephrite artefacts with ferro-actinolite as the essential mineral, though it is still a possibility. ${ }^{71}$ Since the intermediate member, actinolite, is still a valid mineral name, the series will be referred to here tremoliteactinolite-ferro-actinolite (abbreviated here as TAF-a), with the understanding that most nephrite is formed from tremolite-actinolite.

Nephrite can thus be composed of mainly tremolite or actinolite or both. Nephrite colour is often used to assign a piece to one or the other mineral, but colour is not a good indicator of mineral content or composition, as we will see below. Moreover, in addition to these 'essential minerals', there may be minor accessory minerals present, even when the nephrite is relatively pure, as listed in Table 3. Consequently, nephrite is best considered as a rock consisting of several minerals and various other elements. The latter are both often regarded as 'impurities' but are better regarded as 'bonus ingredients', as they may be very informative. The most important elements that determine whether a calcium amphibole is tremolite or actinolite are iron and magnesium. The way these behave can be seen when examining the TAF-a solid-solution series.

\footnotetext{
${ }^{69}$ George Harlow (pers. comm. 26 November 2016), conforming to Hawthorne et al. (2012). Unfortunately Harlow et al. (2014: 340) state that 'actinolite is no longer a valid mineral species' and that 'tremolite [now] spans the compositions formerly termed actinolite' (my insertion); they refer to Hawthorne et al. 2013 on this issue, but the publication in question is Hawthorne et al. (2012), which does not contain these revisions, and Hawthorne himself says that the statement above is not true (Frank Hawthorne pers. comm. by email 14 December 2016): actinolite is a valid mineral species as given in the September 2017 IMA list, as redefined in 2012.

${ }^{70}$ Harlow et al. (2014: 340).

${ }^{71}$ George Harlow, Yoshiyuki Iizuka, and Frank Hawthorne (pers. comm. by email, 26 November 2016 and 3 January 2017). According to Pat Daly (pers. comm 16 February 2017), the attribution of a darkcoloured zhang blade to ferro-actinolite (Casadio et al. 2007) is problematic in that EDXRF (Energy Dispersive X-ray Fluorescence) must avoid the preferred orientation of crystals and no accommodation was mentioned; also no chemical analysis was done to assess the blade composition. The authors Casadio and Douglas agree that the results might be misleading (by email 27 February 2017 and 7 March 2017).
} 
Table 3. Composition analysis of a 'nearly ideal tremolite' with a nominal formula of $\mathrm{Ca}_{2} \mathrm{Mg}_{5} \mathrm{Si}_{8} \mathrm{O}_{22}(\mathrm{OH})_{2}$ from Susa Valley, Italy. Major, minor, and trace elements, given as oxides where appropriate, are demarcated by solid horizontal lines and ordered by declining abundance. The minor and trace elements indicate 'impurities' even in a 'nearly ideal tremolite' and are not represented in the chemical formula.

\begin{tabular}{lll}
\hline Oxide & Element & $\% \mathrm{wt}$ \\
\hline $\mathrm{Major}$ elements $>1 \%$ & & $=97.69 \%$ \\
$\mathrm{SiO}_{2}$ & silicon & 58.51 \\
$\mathrm{MgO}$ & magnesium & 23.74 \\
$\mathrm{CaO}$ & calcium & 13.29 \\
$\mathrm{H} 2 \mathrm{O}$ & hydrogen & 2.15 \\
\hline $\mathrm{Minor}$ elements $0.1 \%-1 \%$ & & $=1.52 \%$ \\
$\mathrm{Fe}^{+2} \mathrm{O}$ & iron(II) & 0.99 \\
$\mathrm{Fe}^{+3}{ }_{2} \mathrm{O}_{3}$ & iron(III) & 0.20 \\
$\mathrm{Na}_{2} \mathrm{O}$ & sodium & 0.20 \\
$\mathrm{MnO}$ & manganese & 0.13 \\
\hline $\mathrm{Trace}_{2}$ elements $<0.1 \%$ & & $=0.22 \%$ \\
$\mathrm{~F}$ & fluorine & 0.07 \\
$\mathrm{Al}{ }_{2} \mathrm{O}_{3}$ & aluminium & 0.05 \\
$\mathrm{~K}_{2} \mathrm{O}$ & potassium & 0.04 \\
$\mathrm{Cl}$ & chlorine & 0.03 \\
$\mathrm{TiO}_{2}$ & titanium & 0.02 \\
$\mathrm{TOTAL}$ & & $99.43 \%$ \\
\hline
\end{tabular}

Sources: Data compiled from Ballirano et al. (2008); definitions of major, minor, and trace elements taken from Blake (2001: 87).

\section{Nephrite incorporating solid-solution minerals}

'Jade is a complex material and a comprehensive account of its composition, properties and occurrence would require a mineralogical textbook. ${ }^{\cdot 72}$

This paper does not purport to be a textbook, but considerable background information in geochemistry, metamorphic petrology, and plate tectonics is critical to understanding the genesis and nature of jade in China. I will try to make this excursion into chemical issues brief but useful, while acknowledging my shallow expertise and the challenges of constantly changing understanding and interpretation.

The TAF-a series belongs to calcium amphibole minerals, as seen in Table $4,{ }^{73}$ based on calcium-Ca, hence the 'calcium', and their crystal structure $(C 2 / m)$. The IMA-approved minerals of the TAF-a series have a silicate component $\mathrm{Si}_{8} \mathrm{O}_{22}$, and they contain a hydroxide $(\mathrm{OH})_{2}$ component. Elements that distinguish them are the relative proportions of magnesium- $\mathrm{Mg}$ and ferrous iron $\mathrm{Fe}^{2+}$ also written as iron(II). In Table 4, the end-member formula for tremolite excludes all iron; however, this is

\footnotetext{
${ }^{72}$ Middleton \& Freestone (1995: 413).

${ }^{73} \mathrm{~F}$-a is properly abbreviated as Fe2-Act (Siivola \& Schmid 2007).
} 
Table 4. TAF-a mineral species and variants.

Tremolite-actinolite-ferro-actinolite series ${ }^{a}$

$\mathrm{Ca}_{2}(\mathrm{Mg}, \mathrm{Fe})_{5} \mathrm{Si}_{8} \mathrm{O}_{22}(\mathrm{OH}, \mathrm{F}, \mathrm{Cl})_{2}$

Approved mineral species:

Tremolite $^{b}$

end-member formula:

calcium magnesium silicate hydroxide

$\square \mathrm{Ca}_{2} \mathrm{Mg}_{5} \mathrm{Si}_{8} \mathrm{O}_{22}(\mathrm{OH})_{2}$

Actinolite

calcium magnesium iron(II) silicate

compositional range:

hydroxide

$\square \mathrm{Ca}_{2}\left(\mathrm{Mg}_{4.5-2.5} \mathrm{Fe}_{0.5-2.5}\right) \mathrm{Si}_{8} \mathrm{O}_{22}(\mathrm{OH})_{2}$

Ferro-actinolite $^{\mathrm{b}}$

end-member formula:

calcium iron(II) silicate hydroxide

fluoro-tremolite ${ }^{\mathrm{f}}$

$\square \mathrm{Ca}_{2}\left(\mathrm{Fe}^{2+}\right)_{5} \mathrm{Si}_{8} \mathrm{O}_{22}(\mathrm{OH})_{2}$

$\square \mathrm{Ca}_{2} \mathrm{Mg}_{5} \mathrm{Si}_{8} \mathrm{O}_{22} \mathrm{~F}_{2}$

Other variants of tremolite in the literature:

parvo-manganotremolite ${ }^{c}$

$\square\left\{\mathrm{CaMn}^{2+}\right\}\left\{\mathrm{Mg}_{5}\right\}\left(\mathrm{Si}_{8} \mathrm{O}_{22}\right)(\mathrm{OH})_{2}$

soda tremolite ${ }^{\mathrm{d}}$

chrome-tremolite ${ }^{\mathrm{d}}$

mangan-tremolite ${ }^{\mathrm{e}}$

tremolite-glaucophane ${ }^{\mathrm{d}}$

$\mathrm{Na}_{2} \mathrm{Ca}(\mathrm{Mg}, \mathrm{Fe})_{5}\left(\mathrm{Si}_{8} \mathrm{O}_{22}\right)(\mathrm{OH})_{2}$

$\mathrm{Ca}_{2}(\mathrm{Mg}, \mathrm{Cr})_{5} \mathrm{Si}_{8} \mathrm{O}_{22}(\mathrm{OH})_{2}$

$\mathrm{Ca}_{2}(\mathrm{Mg}, \mathrm{Mn})_{5} \mathrm{Si}_{8} \mathrm{O}_{22}(\mathrm{OH})_{2}$

$\mathrm{Na}_{2} \mathrm{Ca}(\mathrm{Mg}, \mathrm{Fe})_{5}\left(\mathrm{Si}_{8} \mathrm{O}_{22}\right)(\mathrm{OH})_{2}$

Note: The $\square$ notation allows for other minor elements in the chemical formula.

Source: Compiled from ${ }^{\text {a }}$ Deer et al. (1997b), ${ }^{\text {b }}$ Hawthorne et al. (2012), ${ }^{\mathrm{c}}$ Mindat (n.d.), ${ }^{\mathrm{d}}$ Nickel \& Nichols (2004),

${ }^{\mathrm{e}}$ Nickel \& Nichols (2009), ${ }^{\mathrm{f}}$ IMA-CNMNC (2017).

unobtainable in Nature, and the compositional range given in Table 5 includes iron. The same for ferro-actinolite: the idealised end-member formula excludes all magnesium, but the compositional range allows a ratio of up to $50 / 50 \mathrm{Mg} / \mathrm{Fe}$. There are other elements (e.g., chromium-Cr, manganese-Mn, aluminium-Al, and sodium-Na) that might be incorporated into the chemical formulae, as seen in Table 4 in the compositions of some tremolite variety samples.

In reality, the composition of tremolite in terms of $\mathrm{Mg} / \mathrm{Fe}$ distribution is best seen in a truncated ternary diagram of the solid-solution series, as shown in Figure $1 .^{74}$ This series exhibits continuous chemical changes from end-member tremolite (on the left), through intermediate-member actinolite (in the middle), to end-member ferroactinolite (on the right). The changes involve reciprocal amounts of magnesium and iron; because the ions of these elements are of similar sizes and valence, they can substitute for each other in the chemical formula, varying antipathetically across the series. Although the boundaries between these minerals are ultimately arbitrary - and varying definitions are possible - the IMA-CNMNC recommends thresholds in the magnesium and iron ratios of $\mathrm{Mg} /\left(\mathrm{Mg}+\mathrm{Fe}^{2+}\right)$ to distinguish them. Table 5 shows these divisions and the chemical compositions (and colours) that are included in these ranges.

${ }^{74}$ Truncated because there are no calcium amphiboles with constitutions in the upper part of the triangle. 


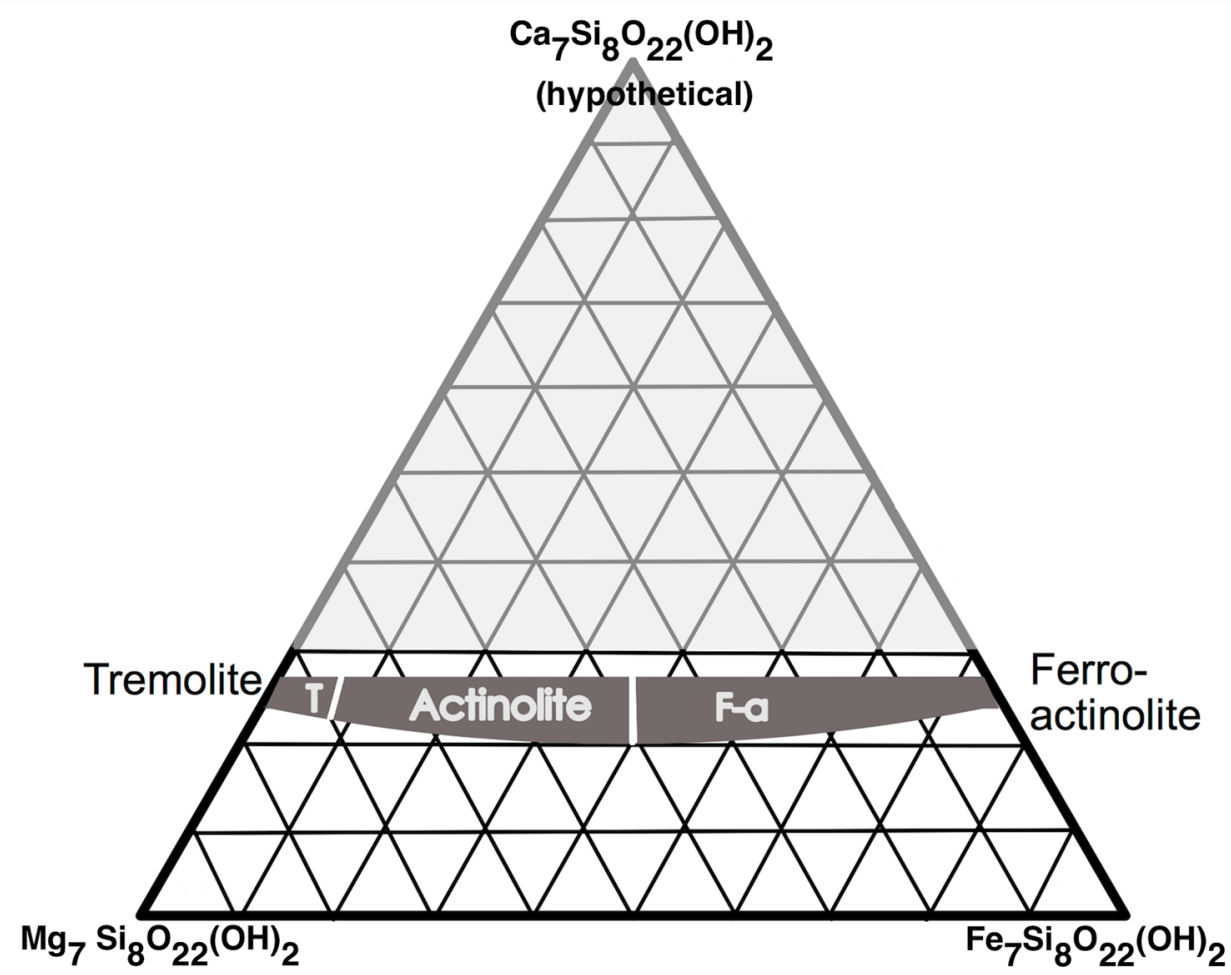

Figure 1. Ternary composition diagram for the tremolite-actinolite-ferro-actinolite continuous solidsolution series (compiled from Wittke 2009: Appendix A and Nelson 2011). The three major elements (calcium, magnesium, and iron) are at 100 per cent in the triangle corners, comprising the minerals indicated by the formula; each parallel line moving away from the corner signals a 10 per cent decrease in the specified element. The divisions between the TAF-a minerals, as calculated by the ratio $\mathrm{Mg} /\left(\mathrm{Mg}+\mathrm{Fe}^{2+}\right)$, are shown as white lines through the solid grey area. There are no known amphiboles that form at the top end of the triangle, hence its fadeout and the hypothetical composition.

Table 5. Distinguishing tremolite, actinolite, and ferro-actinolite in the solid solution.

\begin{tabular}{llll}
\hline & $\mathrm{Mg} /\left(\mathrm{Mg}+\mathrm{Fe}^{2+}\right)$ & Composition range & Colour* \\
\hline Tremolite & $\geqq 0.90$ & $\square \mathrm{Ca}_{2} \mathrm{Mg}_{5} \mathrm{Si}_{8} \mathrm{O}_{22}(\mathrm{OH})_{2}$ & colourless \\
& & to $\square \mathrm{Ca}_{2} \mathrm{Mg}_{4.5} \mathrm{Fe}^{2+}{ }_{0.5} \mathrm{Si}_{8} \mathrm{O}_{22}(\mathrm{OH})_{2}$ & to grey \\
Actinolite & $0.9-0.5$ & $\square \mathrm{Ca}_{2} \mathrm{Mg}_{<4.5} \mathrm{Fe}^{2+}{ }_{>0.5} \mathrm{Si}_{8} \mathrm{O}_{22}(\mathrm{OH})_{2}$ & pale green to \\
& & to $\square \mathrm{Ca}_{2} \mathrm{Mg}_{2.5} \mathrm{Fe}^{2+}{ }_{2.5} \mathrm{Si}_{8} \mathrm{O}_{22}(\mathrm{OH})_{2}$ & dark green \\
Ferro- & $<0.5$ & $\square \mathrm{Ca}_{2} \mathrm{Mg}_{<2.5} \mathrm{Fe}^{2+}{ }_{>2.5} \mathrm{Si}_{8} \mathrm{O}_{22}(\mathrm{OH})_{2}$ & dark green \\
actinolite & to $\square \mathrm{Ca}_{2} \mathrm{Fe}^{2+}{ }_{5} \mathrm{Si}_{8} \mathrm{O}_{22}(\mathrm{OH})_{2}$ & to black \\
\hline
\end{tabular}

* Colour designations are arbitrary and subjective.

Source: Compiled from Deer et al. (1997b: 136-8), Hawthorne et al. (2012: 2036). 
By these definitions, tremolite accounts for a very small part of the series at the far left of the truncated ternary diagram, but its composition may include up to about 10 per cent iron in the $\mathrm{Mg}-\mathrm{Fe}$ total $(\mathrm{Fe} \mathrm{0.5,} \mathrm{Mg} 4.5) .{ }^{75}$ The relative lack of iron in the tremolite end-member makes it colourless; mutton-fat jade (white) would thus be close to this boundary. However, actinolite can have up to 50 per cent $\mathrm{Fe}$ ( $\mathrm{Fe} 2.5, \mathrm{Mg}$ 2.5). The increasing amount of iron and decreasing amount of magnesium produce hues ranging from light to dark green - and most nephrites are so coloured. Similar colours are produced by iron in serpentinite ${ }^{76}$ so colour is not a clue to rock identity (nephrite $v s$ serpentinite) nor to mineral identity (tremolite, actinolite, or serpentine).

Understanding the solid-solution series as a continuum partly accounts for the occurrence of the colour range of Hetian jades; for example, Liu et al. have documented tremolite in white nephrite with ratios of $\mathrm{Mg} /\left(\mathrm{Mg}+\mathrm{Fe}^{2+}\right)$ of $0.98-1.00$, tremolite in green nephrite with ratios of $0.93-0.99$, and actinolite in black nephrite with ratios of $0.63-0.90 .^{77}$ Three jades analysed from a Liangzhu tomb proved to have $\mathrm{Mg} /\left(\mathrm{Mg}+\mathrm{Fe}^{2+}\right)$ values of $0.892,0.871$, and 0.869 ; these are all ostensibly in the actinolite range, but the researchers designate each object as tremolite-actinolite. ${ }^{78}$ Other minerals such as graphite or chromite also influence the colour.

A single ore source can produce nephrites of different mineral compositions. The chemical compositions of Taiwanese jade objects from the Fengtian nephrite-source cluster across the tremolite-actinolite boundary, as shown in Figure 2. The term 'semi-nephrite' has occasionally been used for this combination, ${ }^{79}$ but as noted above, it now more commonly denotes tremolite-actinolite without the felted crystal habit (and therefore not nephrite jade).

As the graphs in Figure 2 show, chemical characterisation serves to identify the relative amounts of magnesium $v s$ iron that correlate with colour (disregarding other causes), but more importantly, they can help identify sources of jade materials. Though 'nephrite' is not a valid mineral name, it is a very useful term that designates a specific felted rock fabric; but to be wholly meaningful, it must be made clear what minerals within the TAF-a series are included in the writer's definition of nephrite.

\section{Summary}

Table 6 encapsulates what we have learned to be important factors in identifying nephrite jade. Those TAF-a minerals that are not felted are not nephrite. All known nephrites are composed of varying amounts of tremolite and/or actinolite. The division

\footnotetext{
${ }^{75}$ Which is only 1 per cent of the total (Fe 0.5 atoms, 41 atoms) in the chemical formula.

${ }^{76}$ Chen Q. et al. (2014).

${ }^{77}$ Liu Z. et al. (2011a: Tables 2, 3, 4); see also Shi M. et al. (2015).

${ }^{78} \mathrm{Gan}$ et al. (2010).

${ }^{79}$ Iizuka (2012).
} 


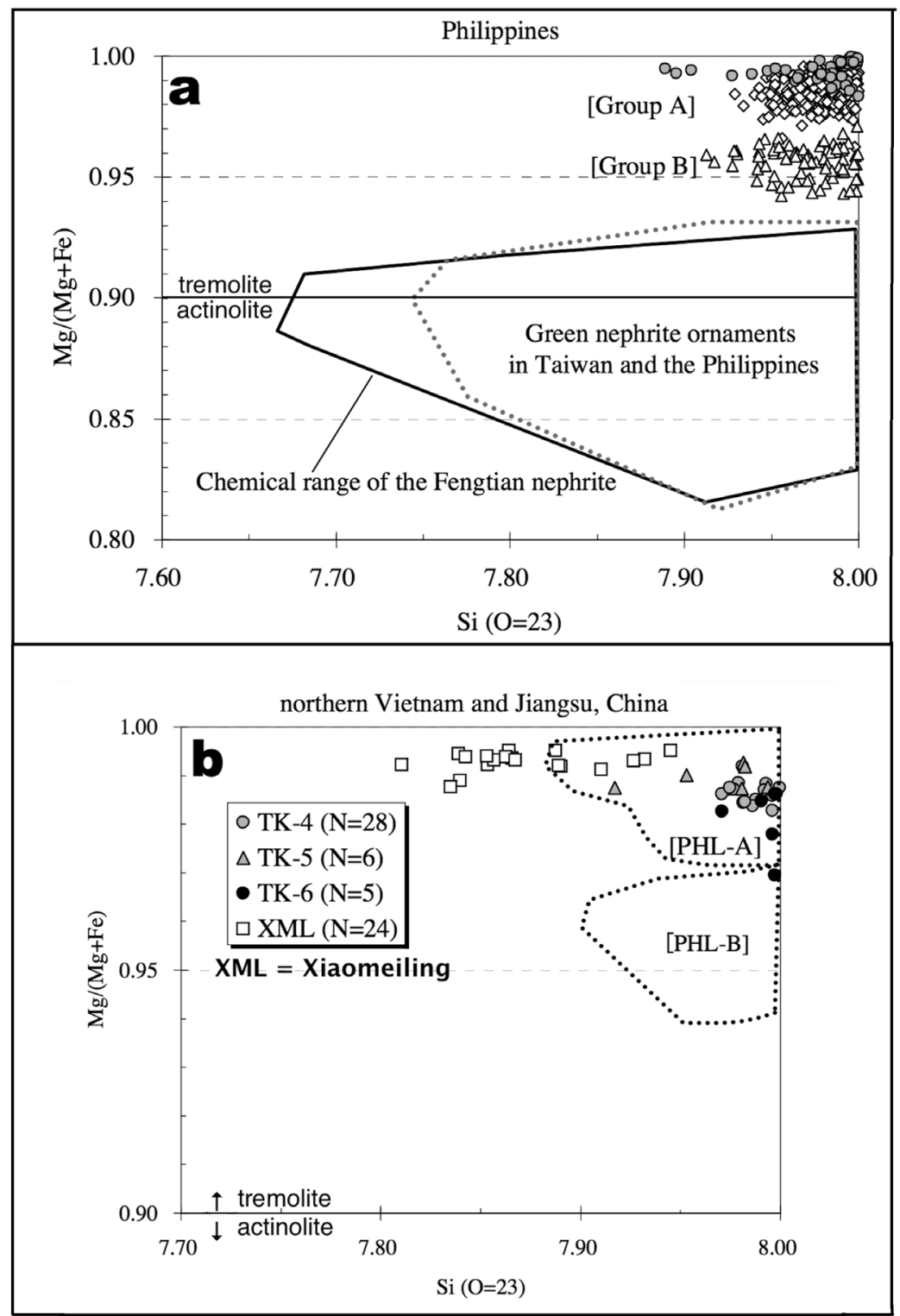

Figure 2. Comparisons of white and green nephrite chemistries in eastern Asia (after Hung et al. 2006: Figure 20.9). The ratio $\mathrm{Mg} /(\mathrm{Mg}+\mathrm{Fe})$ is plotted against the number of silicon atoms per formula unit; the variation in silica is caused by some substitutions of $\mathrm{Al}, \mathrm{Fe}^{3+}$, or $\mathrm{Cr}$ in the crystal lattice.

(a) illustrates the range of Fengtian nephrite as encompassing the $\mathrm{Mg} /(\mathrm{Mg}+\mathrm{Fe})=0.90$ border between tremolite and actinolite; most green nephrite objects from Southeast Asia derive from this source. White (Group A) and white-green-brown (Group B) nephrites from the Philippines are clearly separated chemically.

(b) illustrates Groups A and B in comparison with white nephrites from northern Vietnam (circles, triangles) and Jiangsu (squares). The latter, raw jade sourced from the Xiaomeiling mines, clearly has a different composition than most of the former, believed to be from a local source in Vietnam. 
Table 6. Summary chart of nephrite definitions.

Nephrite rock $=95 \%$ amphibole $($ TAF-a)

composed variously of the following minerals:

\begin{tabular}{|c|c|c|c|c|}
\hline $\begin{array}{l}\text { Essential } \\
\text { mineral }\end{array}$ & $\mathrm{Mg} /\left(\mathrm{Mg}+\mathrm{Fe}^{2+}\right)$ & Texture & & Attribution \\
\hline Tremolite & $\geqq 0.90$ & $\begin{array}{l}\text { felted } \\
\text { not felted }\end{array}$ & $\rightarrow$ & $\begin{array}{l}\text { nephrite } \\
\text { not nephrite }\end{array}$ \\
\hline Actinolite & $0.9-0.5$ & $\begin{array}{l}\text { felted } \\
\text { not felted }\end{array}$ & $\begin{array}{l}\rightarrow \\
\rightarrow\end{array}$ & $\begin{array}{l}\text { nephrite } \\
\text { not nephrite }\end{array}$ \\
\hline $\begin{array}{l}\text { Ferro- } \\
\text { actinolite }\end{array}$ & $<0.5$ & $\begin{array}{l}\text { felted } \\
\text { not felted }\end{array}$ & $\begin{array}{l}\rightarrow \\
\rightarrow\end{array}$ & $\begin{array}{l}\text { rare } \\
\text { not nephrite }\end{array}$ \\
\hline
\end{tabular}

Source: from text above.

between these is arbitrary, but the proportions are important for characterising true jades. Bersani et al. stated that felted ferro-actinolite is 'rare', ${ }^{80}$ and ferro-actinolite jade objects have not yet been clearly documented.

Another final consideration in determining a true jade is how much of an artefact or sample needs to be nephrite when mixed with other minerals. Wen and Jing did not specify percentages but clearly recognised mixtures as hemi-jade. Harlow et al. note that greater than 95 per cent amphibole is 'typical' for nephrites; but for Fengtian jades distributed throughout Southeast Asia, a 90 per cent threshold is used to accommodate additional constituents. ${ }^{81}$ The presence of other minerals in nephrite, making up the remaining 5-10 per cent, will be considered below.

Finally, I have tried to make the distinction clear between the different kinds of 'jade' - not only the different kinds of 'true jades' but of other rocks and minerals which are often termed jade. Thus, the word 'jade' when it occurs alone must always be read with care, since it does not always equate with 'true jade'.

\section{PART TWO: FROM PARENT ROCKS TO HOST ROCKS}

Throughout the literature, one reads that jadeite is formed in serpentinite while nephrite can be formed from either serpentinite or dolomitic rocks. ${ }^{82}$ Part Two addresses these hierarchical relations: first by discussing how to distinguish nephrites formed from different host rocks, and then by examining the formation processes of those host rocks themselves. These processes involve both the transformation of rock under heat and

\footnotetext{
${ }^{80}$ Bersani et al. (2014).

${ }^{81}$ Harlow et al. (2007: 230), Iizuka (2012, and pers. comm. by email 3 January 2017).

${ }^{82}$ As put forward by Wen \& Jing (1992, 1994).
} 
pressure (metamorphism) and fluid interactions (metasomatism). An understanding of these basic geological processes lays the groundwork for examining the geographical locations of such host rocks in the China Mainland in Part Three.

\section{Two types of nephrite}

The use of terms 'nephrite' and 'jadeite' as equivalents is rife in the literature. Based on the foregoing discussion, let us first amend this statement to make them both rocks: nephrite, and jadeitite (a rock) rather than jadeite (a mineral). Next, it is important to note a similar difference among the host rocks: dolomarble and serpentinite. As will be discussed in more detail below, nephrite can form from either dolomarble or serpentinite, whereas jadeite forms in serpentinite. The hierarchical relations between these rocks make the processes easier to understand. For brevity and to avoid repetition, these abbreviations of the two types of nephrite are offered ${ }^{83}$ for nephrite from dolomite (D-nephrite, $\mathrm{dN}$ ) and for nephrite from serpentine (S-nephrite, $\mathrm{sN}$ ).

The main mineral of dolomarble is dolomite $\mathrm{CaMg}\left(\mathrm{CO}_{3}\right)_{2}$, composed of calcium$\mathrm{Ca}$, magnesium $-\mathrm{Mg}$, and carbonate- $\mathrm{CO}_{3}$. Dolomarble is metamorphosed dolomitic limestone, often called 'dolomite' or 'dolostone', but here 'dolomite' will be reserved for the mineral. Nephrite may form through reaction of dolomite with quartz and water to form tremolite-actinolite (and the subsequent felting), calcite and $\mathrm{CO}_{2}$.

Serpentinite is a rock comprised mainly of serpentine minerals. Serpentine is the group name of minerals that have nearly the same chemical formula$(\mathrm{Mg}, \mathrm{Fe})_{3} \mathrm{Si}_{2} \mathrm{O}_{5}(\mathrm{OH})_{4}$ - but different crystal structures (polytypes). Antigorite and lizardite are the main serpentine minerals, with chrysotile being an asbestiform habit of lizardite; it is commonly antigorite that reacts to form tremolite-actinolite.

Serpentinite and dolomarble thus serve as 'host rocks' for the formation of nephrite. Since the turn of the millennium, Chinese scholars have used non-destructive PIXE (Particle Induced X-ray Emission) analysis to distinguish S-nephrite and D-nephrite. ${ }^{84}$ Major findings of the collective research by Zhang et al. ${ }^{85}$ are (1) that the general dividing point among the sampled nephrites according to $\mathrm{Mg}^{2+} /\left(\mathrm{Mg}^{2+}+\mathrm{Fe}^{2+(3+)}\right)$ [abbreviated as the $\mathrm{R}^{*}$ ratio] is drawn at $\mathrm{R}^{*}=0.93$, confirming earlier whole-rock studies; ${ }^{86}$ but (2) that this measure is not entirely accurate in separating D-nephrites

\footnotetext{
${ }^{83}$ In parallel with I-type, S-type, specialised S-type, and A-type granites (Chappell \& White 2001, Kumar \& Singh 2014: 140-1).

${ }^{84}$ Chen T. et al. (2004).

${ }^{85}$ Zhang Z. W. et al. (2010, 2011, 2012).

${ }^{86}$ Wen \& Jing (1992), Zhang Z. W. et al. (2011). Note that this rendering is more specific than the standard $\mathrm{Mg} /(\mathrm{Mg}+\mathrm{Fe})$ given above.
} 


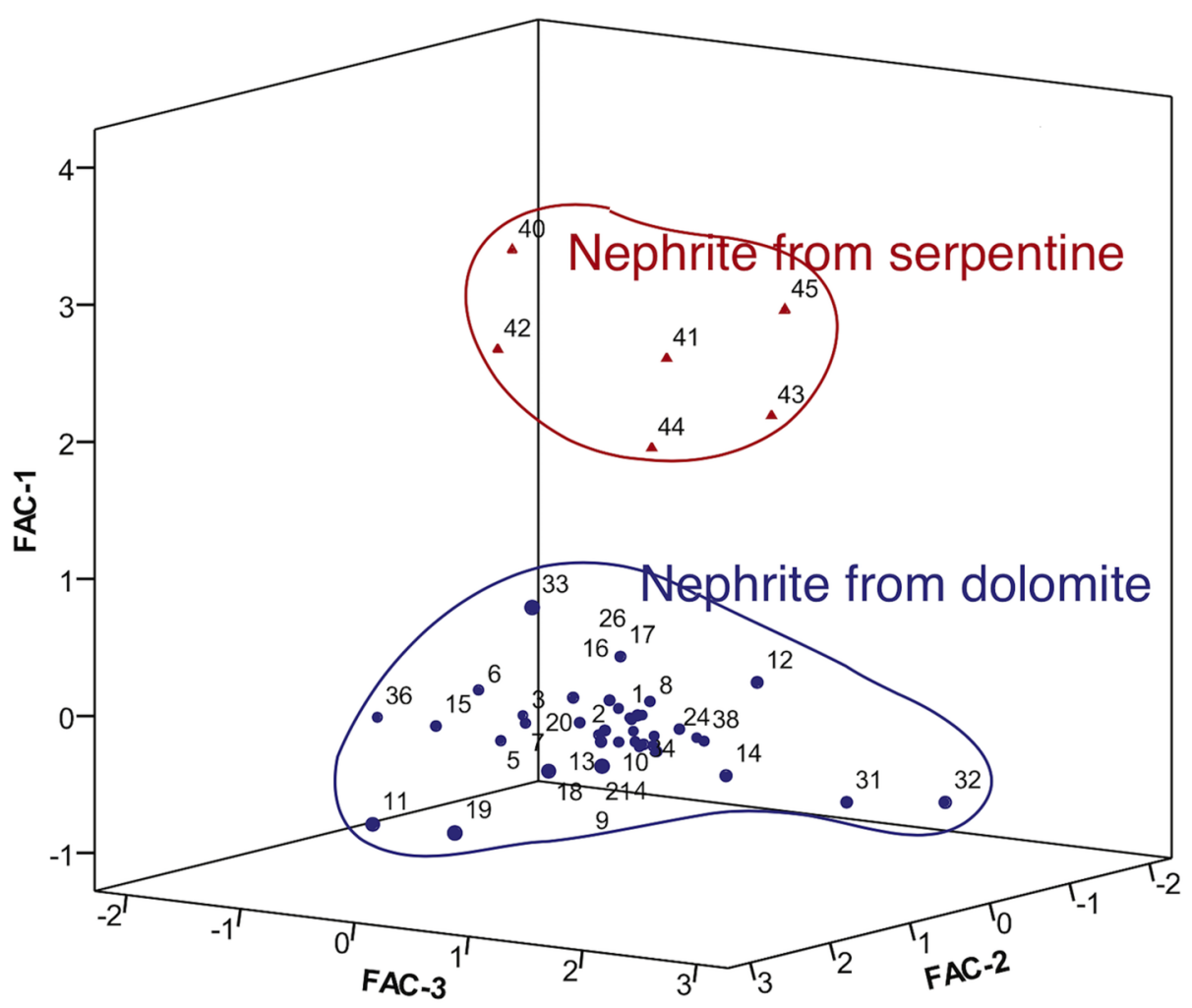

Figure 3. Factor analysis display of nephrite from dolomite and nephrite from serpentine (after Zhang Z. W. et al. 2011: Figure 4). Numbered items are actual samples, with Manas nephrite $(40,41)$ the only S-nephrite from China among others worldwide. Wenchuan samples $(31,32)$ are slightly separated from the rest of the Chinese D-nephrite samples. The ratio of $\mathrm{Mg} /(\mathrm{Mg}+\mathrm{Fe})$ and the three trace elements $\mathrm{Ni}$, $\mathrm{Cr}$, and $\mathrm{Co}$ were the important determinants of the factors.

from S-nephrites, as was demonstrated early on by Wen and Jing. ${ }^{87}$ One sample with very high $\mathrm{Fe}$ content (from presumed local geological circumstances) was grouped with serpentinite-derived nephrites, but its overall composition was closer to D-nephrites. Consequently, factor analysis of element combinations was undertaken to provide better distinction, and the groups clearly separated into $\mathrm{sN}$ above and $\mathrm{dN}$ below, as shown in Figure 3.

That study found that three trace-elements (chromium-Cr, cobalt-Co, and nickel$\mathrm{Ni})$ together with the $\mathrm{R} *$ ratio were crucial in determining the separation. Two types of nephrite were thus recognised: Type I with chemical composition corresponding to tremolite, and Type II with chemical composition corresponding to actinolite. Type-II nephrites 'always contain more transition metals such as $\mathrm{Cr}$, $\mathrm{Co}$, $\mathrm{Ni}$ and so on. ${ }^{88} \mathrm{In}$

${ }^{87}$ Zhang Z. W. et al. (2011), Wen \& Jing (1992: Figure 6).

${ }^{88}$ Zhang Z. W. et al. (2010: 367). 
that study, it is notable that only Manas nephrite from Xinjiang was included in the S-nephrite group (Type II, actinolite) along with New Zealand and British Columbian nephrite; nephrites from Hetian, Yecheng, Xiuyan, Xiaomeiling, and Wenchuan were all D-nephrites (Type I, tremolite).

As more sources and artefacts from archaeological sites are analysed, we shall finally be able to trace mining, production, and consumption processes across the landscape. But prior to examining that landscape, more needs to be discussed about the origin of dolomarble and serpentinite - the host rocks of nephrite.

\section{Metamorphic rocks and minerals}

All four rocks discussed above (nephrite, jadeitite, serpentinite, dolomarble) are metamorphic rocks, one of the three major classes of rocks on Earth: igneous, sedimentary, and metamorphic. Metamorphic rocks are, by definition, transformations of other kinds of rocks, and additional metamorphic processes can act on previously metamorphosed rocks. Rocks before they become metamorphosed are called 'protoliths' or 'parent rocks'. In this case, the parent rocks of serpentinite are igneous rocks of the Earth's mantle (peridotite) or lower oceanic crust (gabbro, basalt), while the parent rock of dolomarble is dolomitic limestone (dolostone).

The essential jade minerals (jadeite, tremolite, actinolite) are also metamorphic minerals whose formation particularly involves fluids (metasomatism). We saw above that tremolite and actinolite can form either from dolomarble or from serpentinite. Jadeite can form from two kinds of metasomatism acting within peridotite or upon blueschist-facies rocks. As true-jade products, jadeitite is rare, while nephrite is more common; but worldwide, nephrite from serpentinite (S-nephrite) is more abundant than nephrite from dolomarble (D-nephrite). Harlow et al. note that nephrite formed from dolomite is relatively rare in the world and yet is the main form of nephrite traditionally used in China. ${ }^{89}$

\section{Metamorphic processes}

It was mentioned above that transformations of mineral chemistry via interactions with circulating fluids (metasomatism) is a major process in forming the true jade minerals. Metasomatism is a class of metamorphism that has been sadly neglected for the past half century but is now 'roaring back into the vocabulary of petrology'. ${ }^{90}$ Metasomatism warrants only four pages in Best's 'bible', Igneous and Metamorphic

\footnotetext{
${ }^{89}$ Harlow et al. (2014: 342-3).

${ }^{90}$ Since 1958 to be exact (Nelson 2011: n.p.).
} 
Petrology, but an 806-page book, Metasomatism and the Chemical Transformation of Rock, is now available on that topic alone. ${ }^{91}$ Thus, understanding nephrite and jadeitite formation via metasomatism is only just beginning, ${ }^{92}$ and this review is no more than an initial report. See Harlow et al.'s chapter on 'Jade' for the current state of knowledge of nephrite jade ${ }^{93}$ the following draws heavily on their work.

Four types of metamorphism concern us here, numbered below. The major difference is between solid-state metamorphism, involving mineral recrystallisation in rock affected by pressure and temperature without melting except at very high temperatures, and metasomatism, germane to jade production and involving chemical change primarily via reaction with fluids (dissolution and precipitation). Although designated as a separate class, metasomatism is now recognised to occur in 'virtually all rocks ${ }^{94}$ and can accompany other types of metamorphism to greater or lesser extents.

One problem here is understanding the origins of dolomitic limestone itself. Dolomitisation of limestone, the replacement of calcium by magnesium in seawater, is not included in metamorphic processes; it is a diagenetic process that occurs at low temperature and pressure (at sea level in ambient temperatures) ${ }^{95}$ This is discussed further below, but for our purposes here, dolomitisation will be included as the first stage of chemical changes leading to true-jade formation.

\section{Metasomatic metamorphism}

1. Metasomatism indicates fluid conditions of change: dissolution/precipitation rather than solid-state metamorphism (recrystallisation). Metasomatism works via fluid transport and chemical replacement: chemical reaction and exchanges of elements between the fluids and existing minerals. Fluids can be of various origins: e.g., circulating seawater, dehydration processes, volcanic-hydrothermal venting, or fluids generated in fault zones.

\footnotetext{
${ }^{91}$ Best (2003), Harlov \& Austrheim (2013).

${ }^{92}$ Liu Y. et al. (2010: 250), Harlow et al. (2014). But see Harlow et al. (2015).

${ }^{93}$ Harlow et al. (2014).

${ }^{94}$ Newton (2014: 155).

${ }^{95}$ 'Diagensis' refers to the transformation of sediments by chemical, physical, and biological meanspossibly including metasomatism but not weathering - as they under undergo lithification under low temperature and pressure.
} 
Solid-state metamorphism (with accompanying metasomatism)

2. Contact metamorphism occurs when an igneous body (magma) intrudes into country rock such as limestone and causes chemical changes, primarily through heating but also through fluid exchange. This results in a local aureole of metamorphic rock around the intrusion. Heat from the igneous intrusion bakes the nearby rocks, causing mineral recrystallisation; fluids exuded beyond those areas cause chemical replacement of minerals to produce a rock called 'skarn'. This type of metasomatism is often called 'contact metasomatism' and is credited with producing most of China's D-nephrite.

3. Regional metamorphism occurs on a large regional scale where rocks are buried deep in the Earth's crust; most changes result from pressure and temperature, but metasomatism can also occur. Limestone is converted into marble generally during regional metamorphism, though some may form on a local scale during contact metamorphism. ${ }^{96}$ S-nephrite generally forms via fluid interactions under conditions of regional metamorphism.

4. Cataclastic metamorphism occurs in fault zones where rocks grind against each other; the friction causes mineral recrystallisation, and fluids are often generated. Both Luanchuan and Dushan jade are products of cataclastic metamorphism and metasomatism.

The traditional display of 'metamorphic-facies' at certain pressures $(\mathrm{P})$ and temperatures $(\mathrm{T})$ is given in Figure 4. Where unmetamorphosed rocks are subjected to these various $\mathrm{P} / \mathrm{T}$ conditions, their minerals experience solid-state recrystallisation to produce minerals characteristic of those $\mathrm{P} / \mathrm{T}$ conditions. The mineral suite and relict textures belonging to the parent rock can reveal whether that parent rock was sedimentary or igneous; both whole minerals and individual elements can be inherited from them. Moreover, rocks may be subject to other processes (oxidation, graphitisation) that change their mineral assemblages and mineral compositions.

The trajectories A, B, and C in Figure 4 are germane to the discussions of jade mineral formation in the following sections. Rocks can often move from greenschist to blueschist conditions, or even blueschist back to greenschist conditions (retrograde metamorphism). The mineral record will generally record these changes.

In all types of metamorphism, new minerals form in temporal sequence and in competition with each other, ${ }^{97}$ depending on sequential changes in pressure, temperature, and fluid composition - with available elements being exchanged or taken up as needed.

\footnotetext{
${ }^{96}$ Imperial College London (2013: Glossary: Marble).

${ }^{97}$ For example, Xiao Y. et al. (2016).
} 


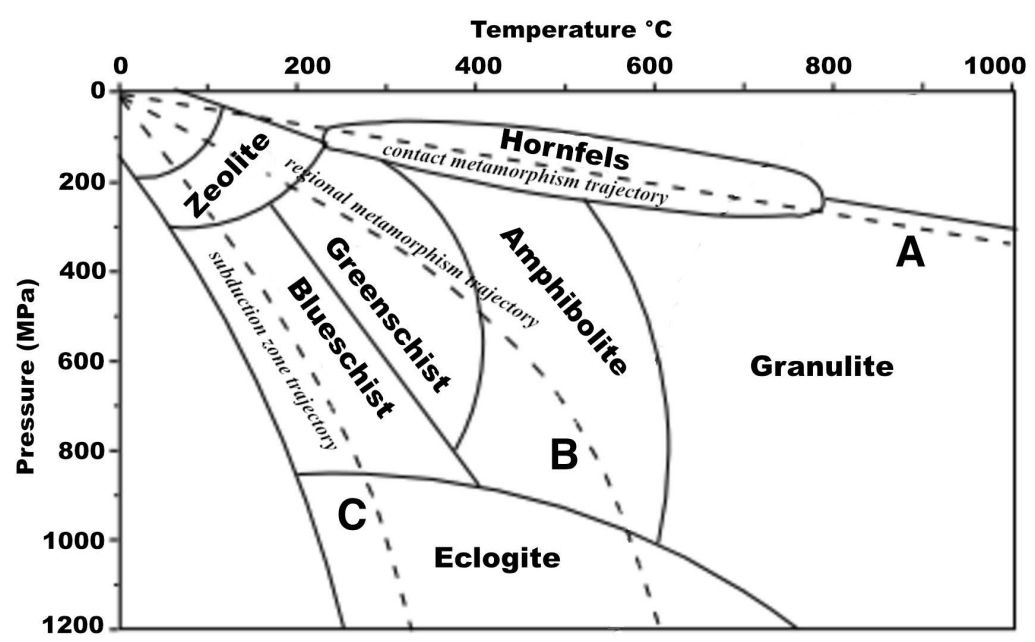

Figure 4. Metamorphic-facies (after Nelson 2011).

The top left corner of the graph represents the Earth's surface, at nominal $\mathrm{P} / \mathrm{T}=0 / 0$. Three trajectories along different geothermal gradients (the Earth gets hotter the deeper you go) are indicated by A, B, and C, occurring in specific tectonic contexts: A in shallow contact metamorphism, B in regional burial where nephrite normally occurs, and $\mathrm{C}$ in deep subduction zones where jadeite is usually formed. These trajectories pass through named metamorphic 'facies' encompassing specific temperatures at specific pressures (depths). These P/T conditions cause different minerals characteristic of each facies to form during metamorphism, especially if the rock body being metamorphosed actually moves via tectonic processes of burial or exhumation.

\section{A metamorphic hierarchy}

In tracing the logical steps of true jade-mineral formation, we are looking at a temporal hierarchy of metamorphic processes acting in sequence on parent rocks to produce host rocks and then producing jade minerals, as shown in Figure 5. Metasomatism is represented by a solid line, and P/T metamorphism by a dashed line. Note that two kinds of $\mathrm{P} / \mathrm{T}$ metamorphism are present: contact metamorphism due to igneous intrusion (Figure 4, Trajectory A), and blueschist-facies metamorphism taking place during subduction (Figure 4, Trajectory C). Because this paper concentrates on Chinese nephrite formation and occurrence, the processes for jadeite formation are abbreviated in Figure 5, to be dealt with elsewhere.

Numbers in parentheses are shown in Figure 5:

- The main sets of parent rocks (1) in question are limestones (high calcium-Ca and high carbonate contents), and upper mantle (peridotite, dunite) / lower ocean floor rock (gabbro, basalt) of ultramafic and mafic compositions, respectively ${ }^{98}$ Other

98 'Mafic' is derived from magnesium and ferric (iron); its opposite, 'felsic' is derived from the mineral family feldspar and silica. These apply to igneous rocks; felsic replaces the use of 'acid' igneous rocks in previous publications. 'Ultramafic' denotes rocks composed predominantly of olivine and/or pyroxene, e.g., mantle rocks. 


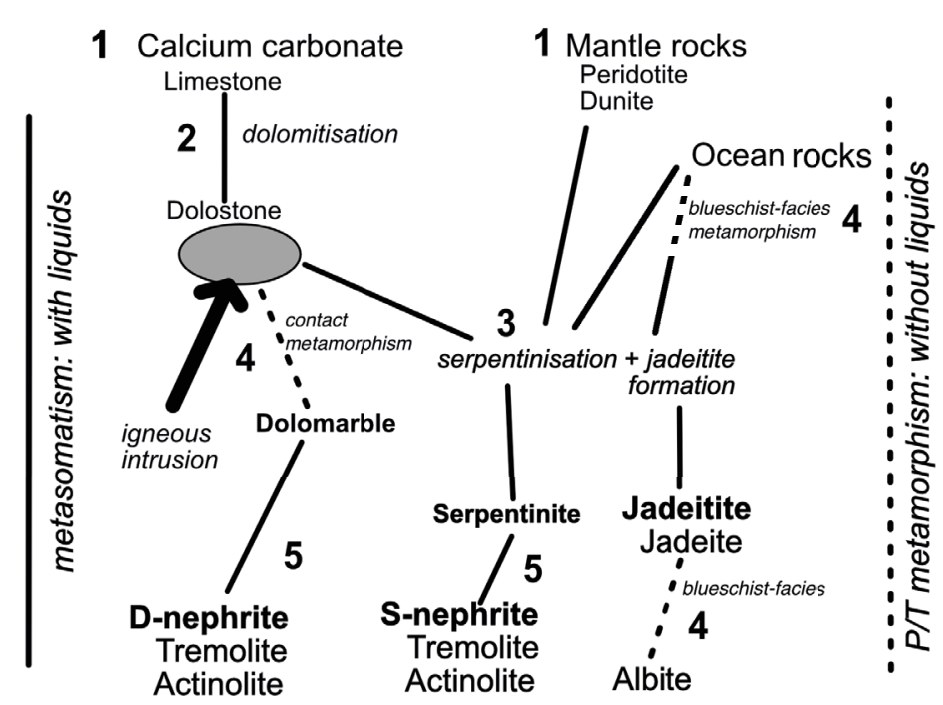

Figure 5. The hierarchical transformation of parent rocks into host rocks where nephrites and jadeitites are formed. Nephrite requires two stages: first dolomitisation (low temperature) and then contact metamorphism (high temperature) followed by metasomatism. Jadeitite in serpentinite appears to form simultaneously with the metasomatic serpentinisation of peridotite; but it can also be created by P/T metamorphism of albite (lower right). (Graph by the author.)

sedimentary and igneous rocks can be involved in jadeite formation but are not represented here. ${ }^{99}$

- These parent rocks can be subjected to three different processes to form three host rocks: dolomitisation (2) of limestone to form dolomitic (magnesian) limestone; serpentinisation of dolomarble/peridotite/gabbro/basalt to form serpentinite (3); and blueschist-facies metamorphism to form blueschists (4), Trajectory C in Figure 4.

- However, two other metamorphic processes can affect dolostone: entire tracts of dolostone can be converted to dolomarble during the $\mathrm{P} / \mathrm{T}$ conditions of regional metamorphism (Figure 4, Trajectory B; e.g., the Dolomite Mountains in Italy); and contact metamorphism (4), resulting from an igneous intrusion into dolostone, can transform the dolostone via the application of heat into dolomitic marble (dolomarble).

- Serpentinite, on the other hand, can be subjected to increasing P/T, from the greenschist-facies to the blueschist-facies or even the eclogite-facies shown in Figure 4. A further solid-state metamorphic possibility is jadeite formed from albite through $\mathrm{P} / \mathrm{T}$ metamorphism (4), as seen at the lower right in Figure 5. This is the only case where jadeite is formed under $\mathrm{P} / \mathrm{T}$ conditions without substantial metasomatism.

- The results of these processes are the two types of nephrite: D-nephrite formed from dolomarble and S-nephrites formed from serpentinite. The latter, moreover,

\footnotetext{
${ }^{99}$ See Harlow et al. (2015).
} 
have three possible parent rocks that were serpentinised: ultramafic rocks, mafic rocks, and dolomarble. These nephrite types will be discussed in detail below.

The problem with metamorphism is that it can affect rocks many times throughout geological history and in many different ways, including reversal or wanderings of the metamorphic trajectories. So, what we find today is a palimpsest of previous processes. To produce true jades, a variety of conditions must be met and maintained; Harlow et al. have noted that jade formation in itself is rare enough, but the preservation of jade minerals is also problematic, as the minerals are subject to replacement or recrystallisation under changing conditions. ${ }^{100}$

\section{Dolomitisation}

Limestone is generally the rock of our shallow ocean reefs or derives from seafloor carbonate muds; ${ }^{101}$ it is formed primarily of fragmentary or dissolved shells and skeletal fragments of marine life, including algae. In the geological record, however, coral reef limestones are relatively recent, and most early limestones are formed from carbonate muds. Limestones and carbonate muds in shallow seas, lagoons, and coastal flats may be subject to dolomitisation by magnesium-rich seawater during the sedimentation process affected by sea-level changes. ${ }^{102}$ Once deposition is completed, limestones and muds may become dolomitised thousands or millions of years later through reaction with circulating fluids. Dolomitisation of lagoon or basin carbonate muds is effective on a large areal scale, ${ }^{103}$ and 'virtually all volumetrically large, replacive dolostone bodies are post-deposition and formed during some degree of burial' ${ }^{104}$

The major minerals of limestone are calcite and aragonite, which both have the chemical formula (but different crystalline structures) $\mathrm{CaCO}_{3}$. Where limestone or lime mud is exposed to magnesium-rich water, some calcium may be replaced by magnesium; magnesite $\mathrm{MgCO}_{3}$, another carbonate mineral (which does not contain calcium) can also form. If more than one quarter of the calcium is replaced by magnesium, the rock becomes dolostone (dolomitic limestone), comprised mostly of the mineral dolomite: calcium magnesium carbonate $\mathrm{CaMg}\left(\mathrm{CO}_{3}\right)_{2}$.

Once dolostone is formed, it can be metamorphosed by heat and pressure, resulting in dolomitic marble (dolomarble). Impurities in the original dolostone can form new minerals when the dolostone recrystallises under regional metamorphic conditions (Trajectory B in Figure 4). Tremolite marbles form in the lower to mid-amphibolite-

\footnotetext{
${ }^{100}$ Harlow et al. (2014: 339-40, 357).

${ }^{101}$ Here, 'mud' is a grain-size designation and does not imply a significant amount of silt; the grains are primarily carbonates $\left(\mathrm{CaO}_{3}\right)$.

${ }_{102}$ Machel (2004: 11, 46).

${ }^{103}$ Moore (1989: 159-60).

${ }^{104}$ Machel (2004: 7).
} 
facies. ${ }^{105}$ Note that the major chemical elements of dolomarble, $\mathrm{Ca}$ and $\mathrm{Mg}$, are primary constituents of tremolite and actinolite. Also note that these rocks lack silica, which is an important component of nephrite supplied to dolomitic rock by igneous rocks during contact metasomatism.

\section{Serpentinisation}

Peridotite is the main rock type of the Earth's upper mantle; gabbro is the commonest rock type of the lower ocean crust, as shown in Figure 6. Peridotite (a source of the olivine birthstone, peridot) has several varieties depending on the relative amounts of

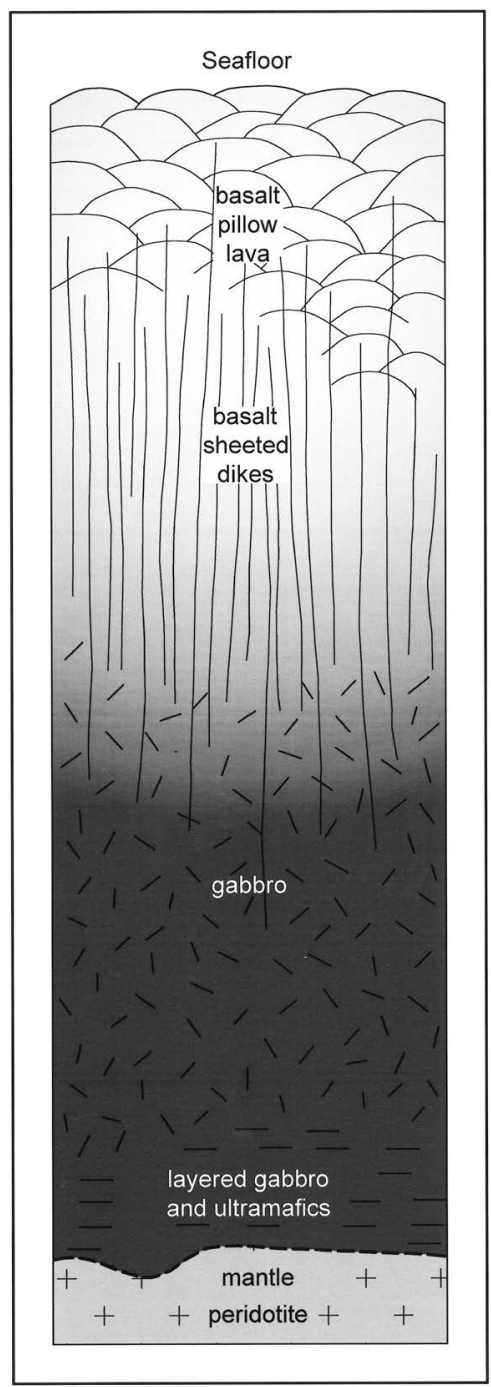

Figure 6. A typical stratigraphic column of oceanic crust (redrawn from Tucholke 1998: 1 by Durham Archaeological Services). The oceanic crust rests on the upper mantle, comprised mainly of the rock peridotite. The crust itself is composed of gabbro and basalt; it is overlain by seafloor sediments, including chert and mud (carbonate or silicic), and it may support some hot-spot volcanics. The ocean crust is usually formed at a mid-ocean ridge, but may also be produced elsewhere, for example, at a spreading centre in a back-arc basin.

${ }^{105}$ Imperial College London (2013: Glossary: Dolomarble). 
its three major constituent minerals; these are (1) the olivine solid-solution series $\left(\mathrm{Mg}^{2+}, \mathrm{Fe}^{2+}\right)_{2} \mathrm{SiO}_{4}$; (2) orthopyroxene minerals incorporating primarily $\mathrm{Ca}, \mathrm{Mg}, \mathrm{Fe}$; and (3) silica. Gabbro usually contains these three plus plagioclase feldspar, which contains $\mathrm{Na}, \mathrm{Ca}, \mathrm{Al}$, and silica. Peridotites are serpentinised with the addition of water, which reacts with the anhydrous silicates to produce new minerals, mainly serpentine, and expands the rock's volume. Water reacting with gabbro to make serpentine carries the $\mathrm{Na}, \mathrm{Ca}$, and some silica out of the resulting rock.

The serpentine minerals that form during serpentinisation are the serpentine polymorphs antigorite, lizardite, and/or chrysotile (the last widely known as the major asbestos mineral $),{ }^{106}$ with the general chemical formula $(\mathrm{Mg}, \mathrm{Fe})_{3}(\mathrm{Si})_{2} \mathrm{O}_{5}(\mathrm{OH})_{4}{ }^{107}$ They are softer than the jade minerals, ranging from 2.5 to 3.5 on the Mohs scale. A rock formed primarily of any of these three serpentine minerals is termed serpentinite; this rock can yield 'ornamental serpentine', a material good for carving and often called 'serpentine jade'108_ not to be confused with nephrite formed in serpentinite (S-nephrite, described below). Bowenite is a different, particularly hard form of serpentine that is suitable for carving. Antigorite is also used for ornaments and termed 'new jade' (xinyul) or 'new mountain jade' (xinshanyu).

Note that the serpentine minerals do not contain calcium, a major constituent of nephrite. Thus, the calcium must be retained from the igneous parent rock or be supplied otherwise: for example, by seawater. As above, silica is necessary for nephrite formation; unlike dolomarble, however, serpentinite is rich in silica, or silica can be supplied by contact and metasomatic exchange with an igneous rock. ${ }^{109}$

The processes and results of serpentinisation are much more complicated and chemically diverse than with dolomitic rocks. Serpentinite is composed of a variety of minerals: predominantly the serpentine minerals, minor magnetite and variable minor brucite, magnesite, calcite, dolomite, and talc. Minor chromite, clinopyroxene, orthopyroxene, and olivine may remain as relics of the original peridotite. Serpentinite itself and the serpentine minerals are highly variable in colour from green to brown to black-green; the green is caused by iron and black spots are usually caused by magnetite. Many of the trace elements and minerals of serpentinite are inherited from its parent rock (usually peridotite) and can be passed on to nephrite.

\footnotetext{
${ }^{106}$ Malpas (1992: 8); chrysotile is considered a growth 'habit' of lizardite, not a separate mineral (George Harlow pers. comm. 2 March 2017); it has been redefined (Rd) in the IMA mineral list (IMA-CNMNC 2017a).

${ }^{107}$ Minerals.net (n.d: 'antigorite').

${ }^{108}$ Mindat.org: www.mindat.org/min-41710.html, Chen Q. et al. (2014).

${ }^{109}$ Frost \& Frost (2014: 204).
} 
The parent and host rocks for nephrite and jadeitite formation-limestones and peridotite and gabbro/basalt - are rocks of the oceanic crust and upper mantle. What on Earth are they doing in continental settings where they can be mined for jade?

\section{PART THREE: NEPHRITE AND PLATE TECTONICS}

In this section, the geography of nephrite localities in China will be examined. As ever, geological processes control those localities, so a brief discussion of relevant aspects of plate tectonics here will pave the way for examining individual occurrences of jade formation in Part Four.

\section{Locations of host rocks}

Since 2005, maps have been produced that illustrate a worldwide geographical correlation between nephrite with ophiolites, as shown in Figure $7 .{ }^{110}$ This is because

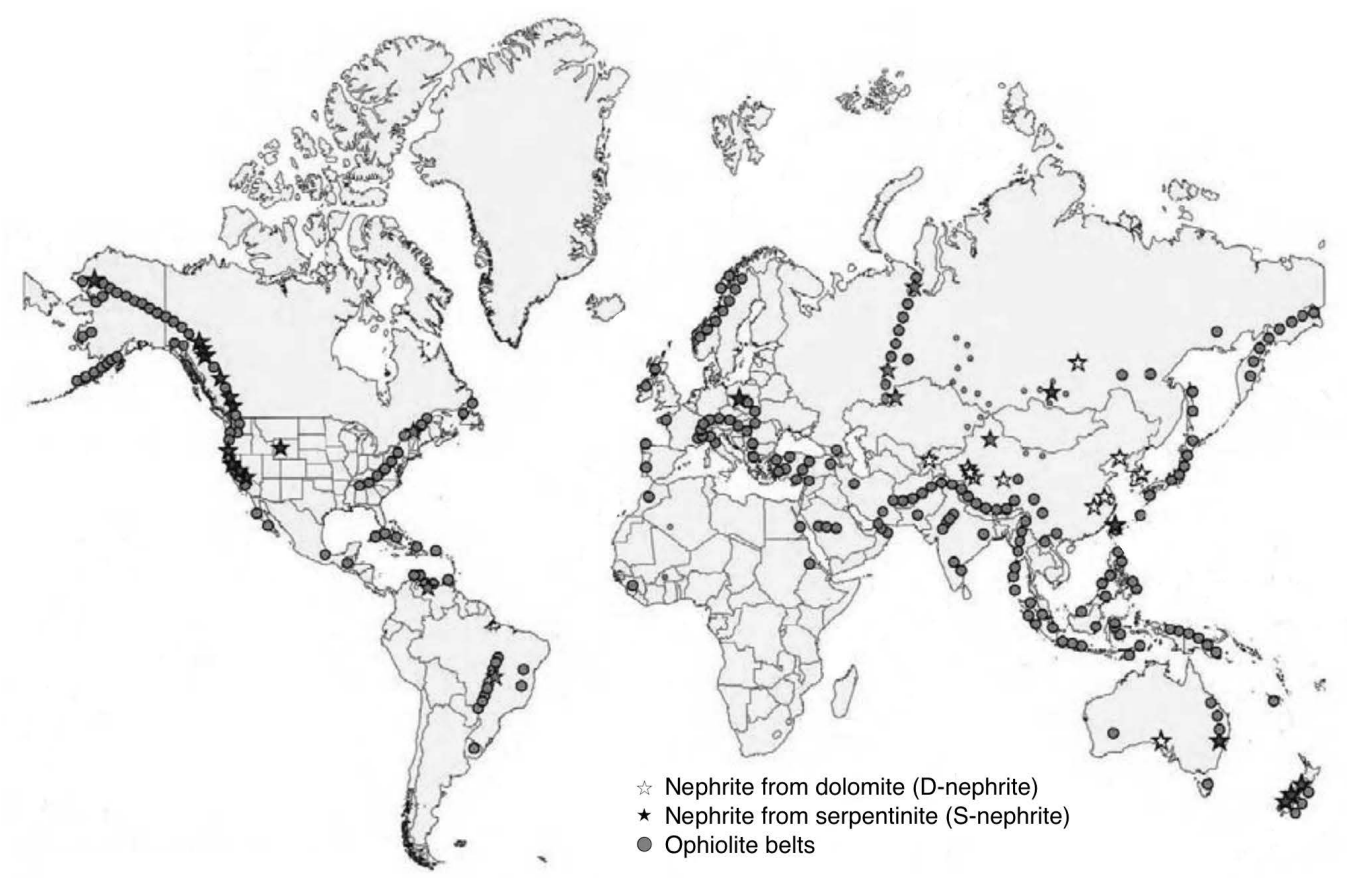

Figure 7. Worldwide nephrite sources and ophiolite distributions (after Harlow et al. 2014: Figure 10-23, with permission). In East Asia, the relationships of nephrite from serpentinite and nephrite from dolorock are not clear at this scale, but are demonstrably not related to the major worldwide distribution of ophiolite, with permission.

${ }^{110}$ A more detailed map of 23 ophiolites is given in Zhang Z. H. et al. (1984: Figure 3). 
most non-Chinese nephrite formed in serpentinite, which is a major component of ophiolites. Conversely, most nephrite in China was not formed in serpentinite but from dolomite, as described for Figure 5. Thus, there are three general problems with this map: first, the nature and significance of ophiolites are lost on those who have never heard of them before; second, the correlation between ophiolites and nephrite as shown here does not hold very well for China; and, third, not all sources of nephrite in China are depicted on the map. Thus, in discussing the Chinese case, we must understand the geological processes that contribute to the formation of both S-nephrite and D-nephrite: ophiolite emplacement, ${ }^{111}$ limestone accretion, and subduction-zone metasomatism and magmatism. ${ }^{112}$ A map illustrating the general ophiolite belts and major nephrite sources in China is shown in Figure 8.

\section{What is an ophiolite?}

There are nine different types of ophiolite (sensu lato) that are formed in different tectonic settings but most commonly in a 'suprasubduction' zone- - on the continental side of a subduction trench in fore-arc or back-arc basins. ${ }^{113}$ These consist mainly of fragments of oceanic crust and Earth mantle that have been incorporated into the continental land surface. The most complete ophiolite (sensu stricto) is a vertical slice of oceanic crust and underlying mantle rock (peridotite) preserving the vertical stratigraphy from top to bottom, as seen in Figure 6: ocean floor sediments $>$ cherts $>$ basalt $>$ gabbro $>$ peridotite (e.g., the Troodos ophiolite in Cyprus) — but few ophiolites exhibit all of these properties. It is recommended that to be called an ophiolite, a rock body should have at least peridotite, basalt, and basalt pillow lava in clear relationsotherwise they should be called 'possible ophiolites', ${ }^{114}$ but 'sliver[s] of serpentinite, gabbro, dolerite, or basalt' from oceanic sources occurring on land have all been termed ophiolites. ${ }^{115}$

Ophiolites are associated with orogenic 'mountain-building' zones where subduction was followed by collision. ${ }^{116}$ As one can see from Figure 7, the ophiolite chains generally follow mountain chains: the Rockies, the Appalachians, the Urals, the Alps, etc. These mark the locations of past and present subduction zones. In East Asia, the present-day subduction zones are marked by the deep trenches running

\footnotetext{
${ }^{111}$ The proper term for emplacement is 'obduction', complementary to 'subduction'; the former adds to the landmass, the latter draws materials down into the mantle.

${ }^{112}$ For a general introduction to subduction zone processes, see Barnes $(2003,2008)$ using Japan as a case study, then Yuan et al. (2009) for China.

${ }^{113}$ Dewey (2003), Dewey \& Casey (2011), Robinson \& Zhou (2007).

${ }^{114}$ Robinson \& Zhou (2007: 303).

${ }^{115}$ Dewey \& Casey (2011: 431).

${ }^{116}$ Yuan et al. (2009). The word orogeny comes from the Greek óros (mountain) + geneia (creation).
} 


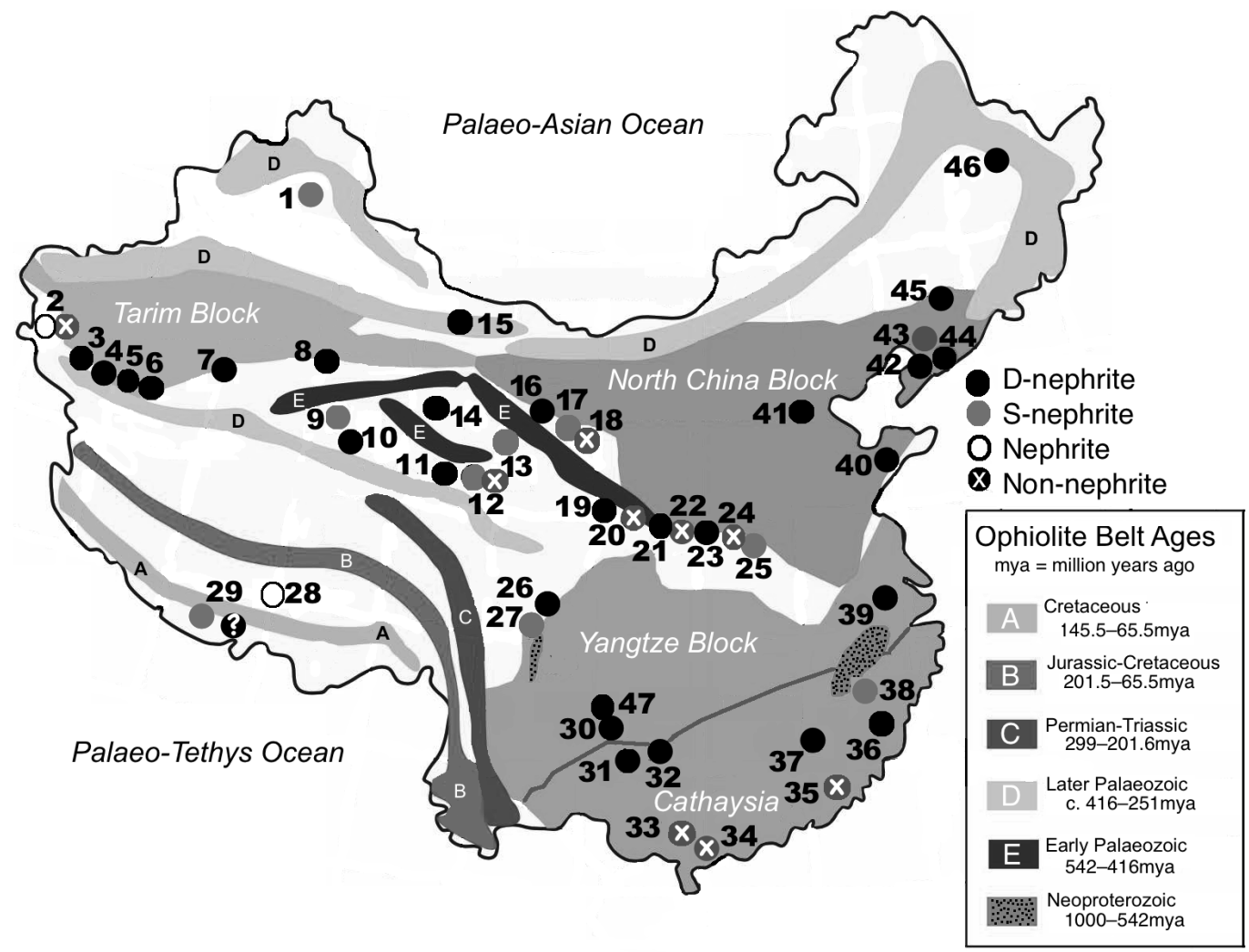

Figure 8. Locations of major Chinese D-nephrite and S-nephrite sources, mapped over ophiolite belts (after Robinson \& Zhou 2008: Figure 1; Zhang Z. W. et al. 2011: Figure 1). Location numbers keyed to Table 7.

down the western Pacific Rim: the Kurile Trench through the Japan Trench; IzuBonin into the Marianas Trench; and the Ryukyu and Philippine Trenches.

Currently, China is not directly exposed to any operating subduction zones, but ophiolites occur throughout the country, marking ancient subduction zones mainly in the west-southwest and north. When subduction begins, oceanic crust (usually formed at spreading centres in back-arc basins such as the Japan Sea Basin, or in fore-arc positions) is fragmented, and some is thrust (obducted) onto land when the ocean/ basin closes under pressure of subduction initiation. ${ }^{117}$

There are several ophiolite 'belts' in China of different ages reaching back a billion years. These have been beached, so to speak, by the closing of successive oceans that brought together the cratonic blocks and continental fragments to make up today's China. The major cratons - the Tarim Block, North China Block, and Yangtze Block, as labelled in Figure 8-are thus rimmed with oceanic materials. The ophiolite belts

${ }^{117}$ Thanks to George Harlow for clarification of the timing of this. 
of main interest to jade researchers are remnants of the Palaeo-Asian and PalaeoTethys oceans, which surrounded the Tarim and North China Blocks between $\mathrm{ca} .550$ and 250 mya (Palaeozoic: Cambrian-Permian). ${ }^{118}$ These ophiolite belts may be 'superimposed on one another, suggesting repeated accretion of island arc assemblages in an environment similar to the present-day western Pacific Ocean'. ${ }^{119}$ No ideal ophiolites such as Troodos have survived in China; the ophiolite 'belts' are notional and figuratively encompass many small ophiolitic fragments that have been identified and named. Many of these do not have the three basic rock types required by international standards of identification.

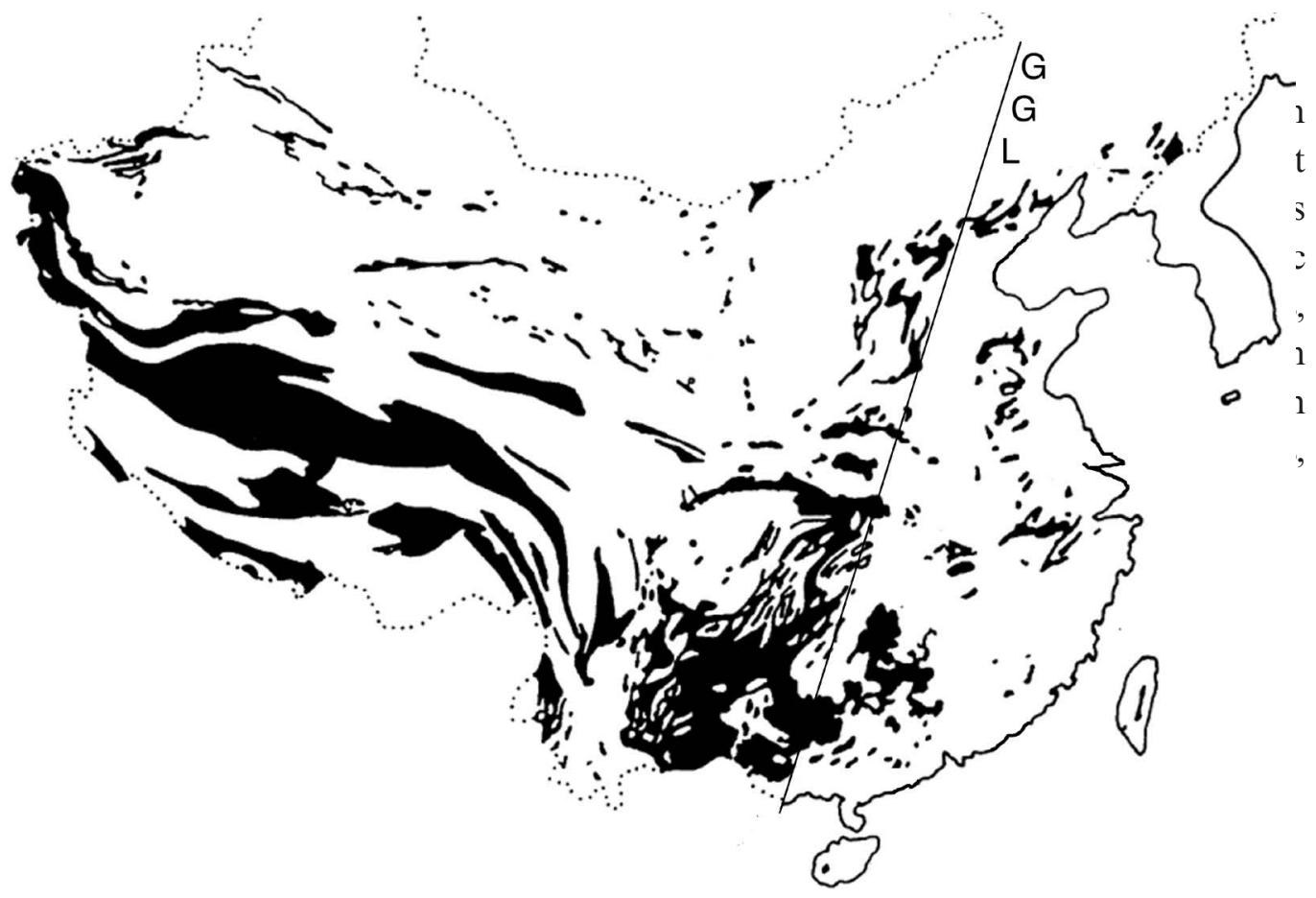

Figure 9. Locations of carbonate rocks in China (after Sweeting 1995: Figure 1; GGL from Niu et al. 2015: Figure 1). The diagonal line is the GGL (Great Gradient Line), dividing the thickness of China's continental lithosphere (crust + upper mantle) of $\geq 150 \mathrm{~km}$ to the west (beneath the plateaus) and $\leq 80 \mathrm{~km}$ to the east. These carbonate bodies could then be affected by the extensive magmatic activity in eastern China that has been attributed to the continent moving eastwards over a stagnant underlying Pacific Plate which emitted enough fluids $c a$. 190-88 mya to generate granitic magma intrusions (Niu et al. 2015). Thus, magmatic intrusions across eastern China that encountered carbonate rocks have the potential to produce nephrite.

\footnotetext{
${ }^{118} \mathrm{mya}=$ million years ago.

${ }^{119}$ Zhang Q. et al. (2007: 308).

${ }^{120}$ National Park Service (n.d.).

${ }^{121}$ Sweeting (2012: 16).

${ }^{122}$ Kojima et al. (2016).
} 
Figure 5 tells us that such limestones had to undergo three processes for tremolite/ actinolite formation: dolomitisation of the limestone to form dolomitic limestone, and then $\mathrm{P} / \mathrm{T}$ metamorphism along Trajectories $\mathrm{A}$ or $\mathrm{B}$ to produce dolomarble, and finally contact metamorphism (Trajectory A, if only B before) for the introduction of silica to form the nephrite minerals. The first happens in the sea before accretion, whereas the latter generally occurs within continental crust. There is subsequent metasomatic transformation of dolomarble to nephrite. Figure 5 indicates that an igneous intrusion into dolomarble was usually the cause of nephrite formation in China. That particular sequence will be examined below for the Alamas dolomarble, but the igneous activity needs accounting for as a subduction-zone process.

\section{Subduction-zone magmatism}

The subducting oceanic crust dehydrates as it descends into the Earth. Fluids exiting the ocean slab enter the overlying mantle rock, lowering the melting temperature of the rock and turning it to magma. The magma rises into the continental crust, sometimes ending as an emplaced pluton (magma chamber) or extruded onto the Earth's surface via a volcano. When hot magma encounters cold country rock, it bakes it, creating a metamorphic aureole around the intrusion, and fluids emanating from there create skarn or metasomatised rock. If the country rock is dolomitic, then there is the potential for nephrite to form. Intrusion of magma into dolomitic rock must overlie an active subduction zone (but we will see below that nephrite can develop without an active igneous intrusion, as in cataclastic metamorphism).

\section{What is serpentinite mélange?}

A final subduction-zone process is the formation of serpentinite mélange. Mélange is a word denoting a miscellaneous mixture of things; when used in Geology, it applies to a rock type that is basically a jumble of different kinds of rocks in some hostmaterial matrix. The common examples are sediment-matrix and serpentinite-matrix mélanges, but in the case of jade, the latter are of interest here. The serpentinite can come from underneath the ocean floor or from the mantle wedge underlying the continental edge, ${ }^{123}$ or from mantle rock exposed to seawater during crustal thinning. ${ }^{124}$ The mélange forms during subduction of an oceanic plate under a continental plate, and the rocks involved can come from either or both plates as material is sheared off during subduction. Serpentinite mélanges make up substantial parts of accretionary complexes (oceanic rocks and sediments bulldozed into the continental edge by the subducting plate) and are usually metamorphosed to greenschist-facies. They can,

\footnotetext{
${ }^{123}$ Shervais et al. (2011).

${ }^{124}$ Reston \& Manatschal (2011).
} 
however, be formed deeper between the subducting slab and the mantle wedge, being metamorphosed at higher pressure to blueschist-facies level.

Because a mélange by definition consists of serpentinite surrounding other rocks, such as ocean-floor-altered gabbro or basalt, conditions are ripe for further metasomatism and nephrite formation. It is important that the basalt and gabbro had previously been exposed to ocean-floor alteration by seawater (metasomatised) into serpentinite before accretion.

Serpentinite mélanges are different in genesis and construction from serpentinite in an ophiolite. It would be useful if these circumstances were noted when describing occurrences of nephrite in serpentinite.

\section{PART FOUR: DERIVATION OF NEPHRITE FROM HOST ROCKS}

The derivation of nephrite from either serpentinite or dolomarble sounds simple, but there are many complications. Nephrite formation depends on several factors: the nature of the host rock and the contact rock, the kind of metamorphism, the tectonic setting, and the elements available in the fluids. Some of these variables appear in Table 7, which lists the main known nephrite sources and some serpentine-jade sources in China. The two types of nephrite described in Figure 5 as D-nephrite and S-nephrite are referred to in the Chinese literature as Type I and Type II, respectively. ${ }^{125}$ For ease in remembering which is which, the notation ' $\mathrm{dN}$ ' from dolomite, and $\mathrm{sN}$ from serpentine might be more helpful. Moreover, note that serpentine jade is actually serpentine minerals, different from S-nephrite.

Below, several types of jade found in China, both nephrites and non-nephrites, will be reviewed as to their geological setting and formation. Several are distinguished by characteristic chemical signatures; these are then compared to some archaeological jades that have been analysed, representing the beginnings of productive efforts to source jade objects to certain deposits.

\section{Nephrite from dolomitic rocks: D-nephrites (dN)}

In the early 1990s, it was thought that nephrite from 'magnesite marble', i.e., dolomarble, was produced by metasomatism as it did not bear the chemical signature of regional metamorphism. ${ }^{126}$ Since then, nephrite from dolomite (D-nephrite) is most generally

\footnotetext{
${ }^{125}$ There are also two types of serpentine jade, using the same designations (Type 1 and Type 2), but these are not relevant here.

${ }^{126}$ Wen (1994).
} 
Table 7. Jade sources in China as reported in the English-language literature

Blanks in the chart indicate incomplete reporting. Location numbers keyed to Figure 8, most common name in bold.

Co. $=$ County; Aut. $=$ Autonomous; Pref. $=$ Prefecture; R. $=$ River; Nephrite types: $\mathrm{dN}=$ nephrite from dolomite, $\mathrm{sN}=$ nephrite in serpentinite. Pronunciations: C. = Chinese; E. = English; J. = Japanese; M. = Mongol; U. = Uyghur; Z. = Zhuang.

\begin{tabular}{|c|c|c|c|c|c|c|}
\hline $\begin{array}{l}\text { Jade name } \\
\text { or source }\end{array}$ & No. & $\begin{array}{l}\text { Prefecture/ } \\
\text { City/County }\end{array}$ & $\begin{array}{l}\text { Host } \\
\text { rock }\end{array}$ & $\begin{array}{l}\text { Contact } \\
\text { rock }\end{array}$ & $\begin{array}{l}\text { Metamorphic } \\
\text { type }\end{array}$ & $\begin{array}{l}\text { Jade } \\
\text { type }\end{array}$ \\
\hline $\begin{array}{l}\text { XINJIANG PRO } \\
\text { C. Manas } \\
\text { U. Manasi }\end{array}$ & $\begin{array}{l}\text { VINC } \\
1\end{array}$ & $\begin{array}{l}\text { = Xinjiang Uyg } \\
\text { Manas Co. } \\
\text { Changji Hui } \\
\text { Aut.Pref. }\end{array}$ & $\begin{array}{l}\text { Autonomous } \\
\text { ultramafic } \\
\text { serpentinite }\end{array}$ & $\begin{array}{l}\text { ion } \\
\text { igneous }\end{array}$ & metasomatism & $\begin{array}{l}\text { sN actinolite, } \\
\text { sN tremolite }\end{array}$ \\
\hline $\begin{array}{l}\text { C. Yecheng } \\
\text { U. Karghilik }\end{array}$ & 2 & $\begin{array}{l}\text { Yecheng Co. } \\
\text { Kashgar Pref. }\end{array}$ & & & & serpentine jade \\
\hline $\begin{array}{l}\text { U. Tashkurgan } \\
\text { (Taxkorgan) }\end{array}$ & 2 & $\begin{array}{l}\text { Taxkorgan } \\
\text { Tajik Aut. Co. } \\
\text { Kashgar Pref. }\end{array}$ & & & & nephrite \\
\hline $\begin{array}{l}\text { C. Pishan } \\
\text { U. Guma (Khotan) }\end{array}$ & 3 & $\begin{array}{l}\text { Pishan Co. } \\
\text { Hotan Pref. }\end{array}$ & & & & D-nephrite \\
\hline $\begin{array}{l}\text { C. Hetian } \\
\text { U. Hotan }\end{array}$ & 4 & $\begin{array}{l}\text { Hetian Co. } \\
\text { Hotan Pref. }\end{array}$ & $\begin{array}{l}\text { dolomite; } \\
\text { Mg marble }\end{array}$ & $\begin{array}{l}\text { intermediate } \\
\text { granite }\end{array}$ & & D-nephrite \\
\hline $\begin{array}{l}\text { U. Yurungkash R. } \\
\text { E. White Jade R. }\end{array}$ & 4 & Hotan Pref. & & & & tremolite \\
\hline $\begin{array}{l}\text { U. Karakash R. } \\
\text { E. Black Jade R. }\end{array}$ & 4 & Hotan Pref. & & & & $\begin{array}{l}\text { tremolite } \\
\text { actinolite }\end{array}$ \\
\hline $\begin{array}{l}\text { E. Cele (Celle) } \\
\text { U. Qira }\end{array}$ & 5 & $\begin{array}{l}\text { Qira Co. } \\
\text { Hotan Pref. }\end{array}$ & & & & nephrite \\
\hline $\begin{array}{l}\text { C. Yutian } \\
\text { U. Keriya }\end{array}$ & 6 & $\begin{array}{l}\text { Yutian Co. } \\
\text { Hotan Pref. }\end{array}$ & dolomarble & granodiorite & & D-nephrite \\
\hline $\begin{array}{l}\text { U. Alamas } \\
\text { C. Alamasi }\end{array}$ & 6 & $\begin{array}{l}\text { Yutian Co. } \\
\text { Hotan Pref. }\end{array}$ & $\begin{array}{l}\text { dolomite } \\
\text { dolomarble }\end{array}$ & & & $\begin{array}{l}\text { tremolite } \\
\text { D-nephrite }\end{array}$ \\
\hline $\begin{array}{l}\text { C. Qiemo } \\
\text { U. Cherchen }\end{array}$ & 7 & $\begin{array}{l}\text { Cherchen Co. } \\
\text { Baiyin'gholin } \\
\text { Mongol Aut. } \\
\text { Pref. }\end{array}$ & carbonate & & & $\begin{array}{l}\text { tremolite } \\
\text { D-nephrite }\end{array}$ \\
\hline $\begin{array}{l}\text { C. Ruoqiang } \\
\text { U. Qarkilik }\end{array}$ & 8 & $\begin{array}{l}\text { Ruoqiang Co. } \\
\text { Baiyin'gholin } \\
\text { Mongol Aut. } \\
\text { Pref. }\end{array}$ & & & & \\
\hline
\end{tabular}


Table 7. Continued.

\begin{tabular}{|c|c|c|c|c|c|c|}
\hline $\begin{array}{l}\text { Jade name } \\
\text { or source }\end{array}$ & No. & $\begin{array}{l}\text { Prefecture/ } \\
\text { City/County }\end{array}$ & $\begin{array}{l}\text { Host } \\
\text { rock }\end{array}$ & $\begin{array}{l}\text { Contact } \\
\text { rock }\end{array}$ & $\begin{array}{l}\text { Metamorphic } \\
\text { type }\end{array}$ & $\begin{array}{l}\text { Jade } \\
\text { type }\end{array}$ \\
\hline $\begin{array}{l}\text { QINGHAI PRO } \\
\text { Eastern Kunlun } \\
\text { Mts } \\
\text { C. dong-Kunlun }\end{array}$ & INCE & $\begin{array}{l}\text { E. Kokonur, Tibets } \\
\text { Central Qinghai }\end{array}$ & $\begin{array}{l}\text { In Amdo } \\
\text { dolomarble }\end{array}$ & $\begin{array}{l}\text { interm } \\
\text { granite }\end{array}$ & & $\begin{array}{l}\text { D-nephrite } \\
\text { tremolite- } \\
\text { actinolite }\end{array}$ \\
\hline $\begin{array}{l}\text { C. Mang'ai } \\
\text { (Mangya) }\end{array}$ & 9 & $\begin{array}{l}\text { Mang'ai Co., } \\
\text { Haixi (M. Qaidam } \\
\text { Mongol \& Tibetan } \\
\text { Aut. Pref. }\end{array}$ & & & & S-nephrite \\
\hline $\begin{array}{l}\text { M. Golmud } \\
\text { C. Ge'ermu }\end{array}$ & 10 & $\begin{array}{l}\text { Golmud City, } \\
\text { Haixi }\end{array}$ & & & D-nephrite & tremolite \\
\hline C. Sanchakou & 11 & $\begin{array}{l}\text { Dulan Co. } \\
\text { Haixi Pref. }\end{array}$ & $\begin{array}{l}\text { dolomitic } \\
\text { limestone }\end{array}$ & gabbro & $\begin{array}{l}\text { hydrothermal } \\
\text { metasomatism }\end{array}$ & D-nephrite \\
\hline $\begin{array}{l}\text { C. Dulan / } \\
\text { Yushitai }\end{array}$ & 12 & $\begin{array}{l}\text { Dulan Co. } \\
\text { Haixi }\end{array}$ & serpentine & & & $\begin{array}{l}\text { serpentine } \\
\text { S-nephrite }\end{array}$ \\
\hline $\begin{array}{l}\text { Qilianshan } \\
=\text { Nanshan } \\
\text { Qiliang Mts = } \\
\text { Nan Mts }\end{array}$ & 13 & $\begin{array}{l}\text { Qinghai- } \\
\text { Gansu }\end{array}$ & serpentine & & & $\begin{array}{l}\text { S-nephrite } \\
\text { actinolite } \\
\text { tremolite } \\
\text { serpentine }\end{array}$ \\
\hline Sanchahe & 14 & $\begin{array}{l}\text { Daqaidam Co., } \\
\text { Haixi }\end{array}$ & marble & $\begin{array}{l}\text { mafic } \\
\text { igneous }\end{array}$ & $\begin{array}{l}\text { contact } \\
\text { metasomatism }\end{array}$ & D-nephrite \\
\hline $\begin{array}{l}\text { GANSU PROVII } \\
\text { C. Mazongshan } \\
\text { Mt. Mazong }\end{array}$ & $\begin{array}{l}\mathrm{JCE} \\
15\end{array}$ & $\begin{array}{l}\text { Subei Co. } \\
\text { Jiuquen City }\end{array}$ & & & & D-nephrite \\
\hline $\begin{array}{l}\text { C. Jiuquen } \\
\text { (C. Suzhou) }\end{array}$ & 16 & $\begin{array}{l}\text { Jiuquen Pref. } \\
\text { City }\end{array}$ & carbonate & & & $\mathrm{dN}$ tremolite \\
\hline $\begin{array}{l}\text { Nanshan } \\
=\text { Qilianshan }\end{array}$ & $\begin{array}{l}17- \\
18\end{array}$ & Gansu & serpentinite & & & $\begin{array}{l}\mathrm{sN} \text { actinolite } \\
\text { tremolite }\end{array}$ \\
\hline $\begin{array}{l}\text { Lintao } \\
\text { (Maxianshan) }\end{array}$ & 19 & $\begin{array}{l}\text { Lintao Co. } \\
\text { Dingxi City }\end{array}$ & carbonate & & & tremolite \\
\hline Yuanyang & 20 & $\begin{array}{l}\text { Wushan Co. } \\
\text { Tianshui City }\end{array}$ & $\begin{array}{l}\text { serpentinised } \\
\text { ultramafic }\end{array}$ & & $\begin{array}{l}\text { hydrothermal } \\
\text { metasomatism }\end{array}$ & serpentine \\
\hline \multicolumn{2}{|c|}{ SHAANXI PROVINCE } & \multicolumn{2}{|c|}{ Qinling Mountains 秦岭 } & & & D-nephrite \\
\hline Fengxian & 21 & $\begin{array}{l}\text { Feng Co. } \\
\text { Baoji City }\end{array}$ & & & & nephrite \\
\hline Lantian jade & 21 & $\begin{array}{l}\text { historic- } \\
\text { exhausted }\end{array}$ & & & & nephrite \\
\hline
\end{tabular}


Table 7. Continued.

\begin{tabular}{|c|c|c|c|c|c|c|}
\hline $\begin{array}{l}\text { Jade name } \\
\text { or source }\end{array}$ & No. & $\begin{array}{l}\text { Prefecture/ } \\
\text { City/County }\end{array}$ & $\begin{array}{l}\text { Host } \\
\text { rock }\end{array}$ & $\begin{array}{l}\text { Contact } \\
\text { rock }\end{array}$ & $\begin{array}{l}\text { Metamorphic } \\
\text { type }\end{array}$ & $\begin{array}{l}\text { Jade } \\
\text { type }\end{array}$ \\
\hline Lantian & 22 & $\begin{array}{l}\text { Lantian Co. } \\
\text { Xi'an City }\end{array}$ & dolomarble & $\begin{array}{l}\text { interm-felsic } \\
\text { igneous }\end{array}$ & $\begin{array}{l}\text { hydrothermal } \\
\text { metamorphism }\end{array}$ & $\begin{array}{l}\text { serpentine jade } \\
\text { Type } 2\end{array}$ \\
\hline \multicolumn{2}{|c|}{ HENAN PROVINCE } & \multicolumn{2}{|c|}{ Qinling Mountains 秦岭 } & \multirow[b]{2}{*}{ metagabbro } & \multirow[b]{2}{*}{$\begin{array}{l}\text { cataclastic } \\
\text { metamorphism }\end{array}$} & \multirow[b]{2}{*}{$\begin{array}{l}\text { tremolite } \\
\text { D-nephrite }\end{array}$} \\
\hline Luanchuan & 23 & $\begin{array}{l}\text { Luanchuan Co. } \\
\text { Luoyang Pref. } \\
\text { City }\end{array}$ & $\begin{array}{l}\text { dolomitic } \\
\text { marble }\end{array}$ & & & \\
\hline $\begin{array}{l}\text { Dushan/ } \\
\text { Nanyang jade }\end{array}$ & 24 & Nanyang City & & \multirow[t]{7}{*}{$\begin{array}{l}\text { gabbro } \\
\text { metamorphi }\end{array}$} & $\begin{array}{l}\text { cataclastic } \\
\text { sm }\end{array}$ & $\begin{array}{l}\text { zoisitised } \\
\text { plagioclase }\end{array}$ \\
\hline Xichuan & 24 & $\begin{array}{l}\text { Xichuan Co. } \\
\text { Nanyang City. }\end{array}$ & $\begin{array}{l}\text { serpentinised } \\
\text { ultramafic }\end{array}$ & & & $\begin{array}{l}\text { serpentine } \\
\text { jade Type } 2\end{array}$ \\
\hline Xichuan & 25 & & serpentinite & & & $\begin{array}{l}\text { actinolite } \\
\text { S-nephrite }\end{array}$ \\
\hline \multicolumn{4}{|c|}{ SICHUAN PROVINCE } & & & D-nephrite \\
\hline Wenchuan & 26 & $\begin{array}{l}\text { Wenchuan Co. } \\
\text { Ngawa Tibetan } \\
\text { \& Qiang Aut. } \\
\text { Pref. }\end{array}$ & $\begin{array}{l}\text { nephrite from } \\
\text { dolomite }\end{array}$ & & & \\
\hline Longxi & 26 & $\begin{array}{l}\text { Longxi town, } \\
\text { Wenchuan Co. } \\
\text { Ngawa Tibetan } \\
\text { \& Qiang Aut. } \\
\text { Pref. }\end{array}$ & carbonite & & & tremolite \\
\hline Shimian & 27 & $\begin{array}{l}\text { Shimian Co. } \\
\text { Ya'an City }\end{array}$ & & & & $\begin{array}{l}\text { S-nephrite } \\
\text { actinolite }\end{array}$ \\
\hline \multicolumn{7}{|c|}{ TIBET AUTONOMOUS REGION = XIZANG AUTONOMOUS REGION } \\
\hline $\begin{array}{l}\text { C. Nagqu } \\
\text { T. Nagchu }\end{array}$ & 28 & $\begin{array}{l}\text { Nagzu Co. } \\
\text { Nagqu Pref. }\end{array}$ & & & & nephrite \\
\hline $\begin{array}{l}\text { C. Xigaze } \\
\text { T. Shigatse }\end{array}$ & 29 & $\begin{array}{l}\text { Xigaze City, } \\
\text { Tsang Prov. }\end{array}$ & $\begin{array}{l}\text { Locs: Lazi, } \\
\text { Saga, Angren } \\
\text { Counties }\end{array}$ & & & $\begin{array}{l}\text { S-nephrite } \\
\text { actinolite }\end{array}$ \\
\hline \multicolumn{7}{|c|}{ GUIZHOU (E. Kweichow) } \\
\hline Luodian & 30 & $\begin{array}{l}\text { Luodian Co. } \\
\text { Qiannan Buyei } \\
\text { \& Miao Aut. Pref. }\end{array}$ & $\begin{array}{l}\text { carbonate } \\
\text { replacement }\end{array}$ & & $\begin{array}{l}\text { thermal } \\
\text { seawater } \\
\text { metasomatism, } \\
\text { contact } \\
\text { metasomatism }\end{array}$ & $\begin{array}{l}\text { D-nephrite, } \\
\text { tremolite }\end{array}$ \\
\hline C. Rongli & 47 & $\begin{array}{l}\text { Ziyun Miao and } \\
\text { Buyei Autonomous } \\
\text { Co., Anshun Pref. } \\
\text { City }\end{array}$ & $\begin{array}{l}\text { calcium } \\
\text { carbonate }\end{array}$ & $\begin{array}{l}\text { basic } \\
\text { intrusive }\end{array}$ & $\begin{array}{l}\text { contact } \\
\text { metasomatism }\end{array}$ & D-nephrite \\
\hline
\end{tabular}


Table 7. Continued.

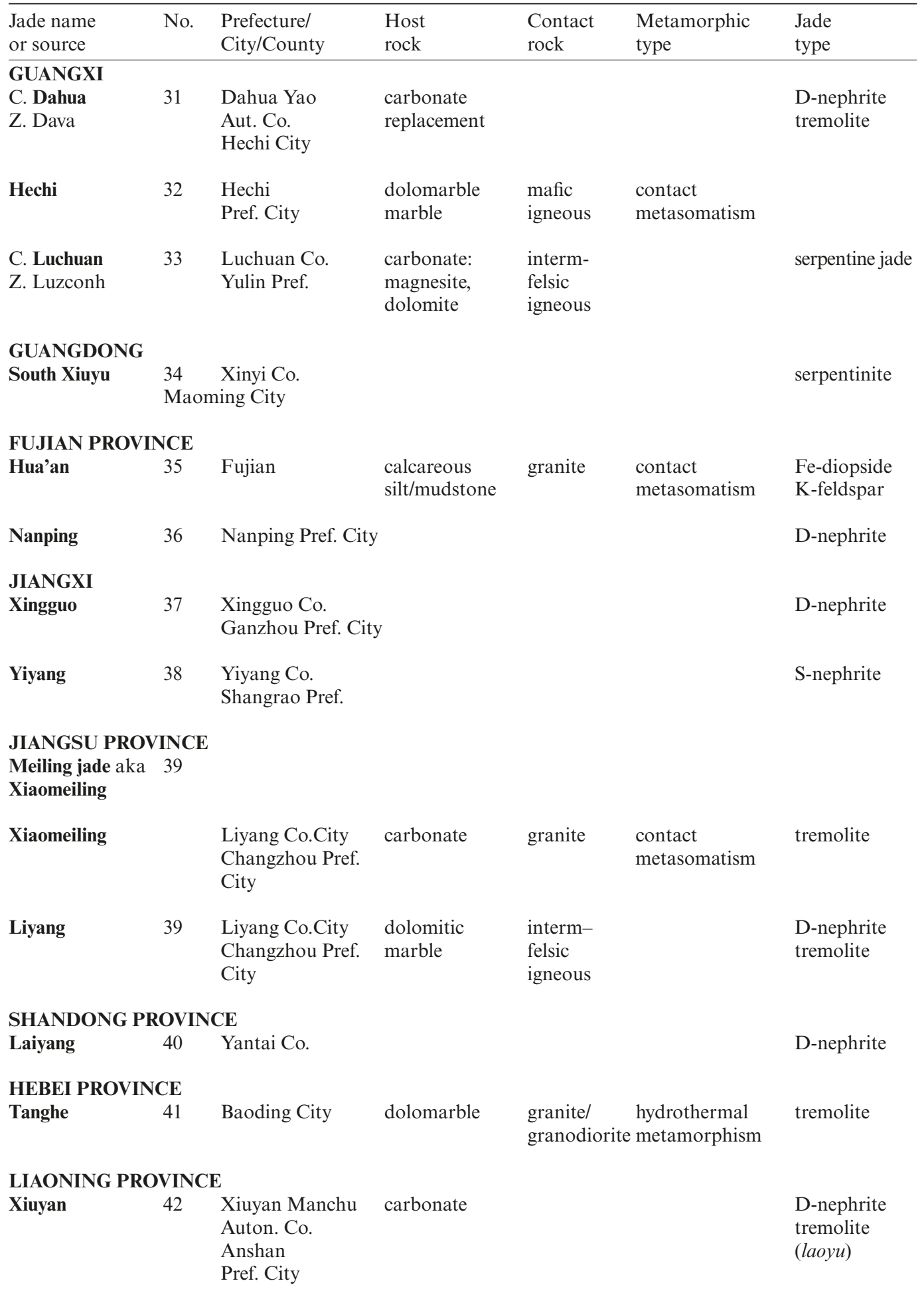


Table 7. Continued.

\begin{tabular}{|c|c|c|c|c|c|c|}
\hline $\begin{array}{l}\text { Jade name } \\
\text { or source }\end{array}$ & No. & $\begin{array}{l}\text { Prefecture/ } \\
\text { City/County }\end{array}$ & $\begin{array}{l}\text { Host } \\
\text { rock }\end{array}$ & $\begin{array}{l}\text { Contact } \\
\text { rock }\end{array}$ & $\begin{array}{l}\text { Metamorphic } \\
\text { type }\end{array}$ & $\begin{array}{l}\text { Jade } \\
\text { type }\end{array}$ \\
\hline Xiuyan & 43 & & $\begin{array}{l}\text { carbonate: } \\
\text { magnesite, } \\
\text { dolomite }\end{array}$ & $\begin{array}{l}\text { interm- } \\
\text { felsic } \\
\text { igneous }\end{array}$ & & $\begin{array}{l}\text { serpentine jade } \\
\text { Type } 1\end{array}$ \\
\hline $\begin{array}{l}\text { Haicheng } \\
\text { Wazii(gou) }\end{array}$ & 42 & $\begin{array}{l}\text { Wazigou town, } \\
\text { Haicheng Co. City } \\
\text { in Anshan Pref. } \\
\text { City }\end{array}$ & & & & D-nephrite \\
\hline Yinkou & 43 & $\begin{array}{l}\text { Yinkou Pref. } \\
\text { City }\end{array}$ & $\begin{array}{l}\text { peridotite } \\
\text { dolomite }\end{array}$ & $\begin{array}{l}\text { serpentised } \\
\text { marble }\end{array}$ & $\begin{array}{l}\text { post-metam. } \\
\text { hydrothermal } \\
\text { alteration }\end{array}$ & serpentine jade \\
\hline Kuandian & 44 & $\begin{array}{l}\text { Kuandian Manchu } \\
\text { Aut. Co., } \\
\text { Dandong Pref. } \\
\text { City }\end{array}$ & carbonate & & & $\begin{array}{l}\text { tremolite } \\
\text { D-nephrite }\end{array}$ \\
\hline \multicolumn{7}{|c|}{ JILIN PROVINCE } \\
\hline Panshi & 45 & $\begin{array}{l}\text { Panshi Co. City, } \\
\text { Jilin Pref. City }\end{array}$ & & & & D-nephrite \\
\hline \multicolumn{7}{|c|}{ HEILONGJIANG } \\
\hline Tieli & 46 & $\begin{array}{l}\text { Tieli Co. } \\
\text { Yichun Pref. }\end{array}$ & & & & D-nephrite \\
\hline $\begin{array}{l}\text { Toushan } / \mathrm{Ta} \\
=\mathrm{J} \text {. Momoy }\end{array}$ & 46 & $\begin{array}{l}\text { Taoshanzhen } \\
\text { village, Tieli }\end{array}$ & $\begin{array}{l}\text { dolomitic } \\
\text { marble }\end{array}$ & $\begin{array}{l}\text { granodiorite } \\
\text { igneous }\end{array}$ & $\begin{array}{l}\text { contact } \\
\text { metamorphism, } \\
\text { metasomatism }\end{array}$ & $\begin{array}{l}\text { tremolite } \\
\text { serpentine } \\
\text { calcite }\end{array}$ \\
\hline
\end{tabular}

Sources: See Table 7A at https://docs.google.com/document/d/1xXLykhWU2lgEtjRcKSFOGzjxmC17p8AIv-rjS_ 1BEyw/edit

described as a product of metasomatism between dolomarble and granitic intrusions, though several nephrites are reportedly produced by dolomarble and mafic igneous rocks such as basalt or gabbro identified in Table 7; but we will also see below an example without igneous intrusion.

There is ongoing discussion of how nephrites are actually formed: ${ }^{127}$ whether there was a 'ready fluid' with all the necessary ingredients waiting to solidify, or whether the fluids delivered new elements to the minerals in the host rocks to cause replacement (somewhat like the replacement of dolomite for calcite in dolomitisation). The case studies below seem to assume the latter mechanism, as do Harlow and colleagues, to frame nephrite formation as 'replacement' of the essential elements in host rock minerals (dolomite, serpentine) to form new minerals - not only tremolite and/or actinolite but other minerals as well.

${ }^{127}$ Harlow et al. (2014: 342, 353-4). 


\section{The Alamas D-nephrites}

The Alamas nephrites from dolomarble, seen in Figure 10, have been intensively analysed and will serve as an example here. They belong to the Qimanyute Ophiolite Belt in the western Kunlun region. ${ }^{128}$ Mineral assemblages indicate temperatures between $330^{\circ}$ and $550^{\circ} \mathrm{C}$, and pressures between 100 and $200 \mathrm{MPa},{ }^{129}$ conforming to the area of the Hornfels-facies on Trajectory A for contact metamorphism in Figure 4. Contact metamorphism occurs at shallow levels and at relatively low temperatures. The zonation of metamorphic changes at Alamas clearly demonstrates the evolution from contact metamorphism due to pressure/temperature changes and contact metasomatism due to the emanation of fluids. Skarn is a rock typically formed by such metasomatism, and here there are three graded series of skarn before three nephrite bodies of increasingly white colour were created, as indicated in Figure 10(b). In addition to the nephrite veining due to contact between the dolomarble and granodiorite, more nephrite bodies occur as lenses and veins within the dolomarble, Figure 10(a), indicating further penetration of fluids via faults and fractures.

Two models have been proposed for Alamas D-nephrite generation; the (aq) below represents components dissolved in water: ${ }^{130}$

1. A single-stage model whereby water and silica(aq) from the magma are added to dolomite to form nephrite. The chemical reaction produces excess calcite and aqueous carbon dioxide(aq).

2. A two-stage model whereby silica(aq) and dolomite react first to form diopside + carbon dioxide(aq), then the addition of water transforms the diopside into nephrite with calcium(aq) and silica(aq) as by-products.

It is not known which of these two mechanisms was operative.

All nephrites at Alamas are tremolite, with a minor component of actinolite having an $\mathrm{Mg} /(\mathrm{Mg}+\mathrm{Fe})$ ratio of 0.72 . Other accessory minerals are calcite, titanite, phlogopite, and diopside. Trace elements include zinc, manganese, zirconium, $<10 \mu \mathrm{g} / \mathrm{g}$ of chromium, cobalt, and nickel. Minerals in associated zonations include spinel (candite), diopside, grossular, serpentine, epidote, tremolite, forsterite, and chlorite.

It is the presence of zoned mineral deposits here that is important for our understanding of prehistoric mining processes used for Hongshan and Liangzhu jades-before the Hetian alluvial deposits were exploited. Miners potentially had access to several different types of mineral in a single geological setting, and they may have supplied a variety of minerals and rocks to stone workers. These probably would

\footnotetext{
${ }^{128}$ Zhang Q. et al. (2016).

${ }^{129}$ Liu Y. et al. (2010, 2011b).

${ }^{130}$ Harlow et al. (2014: 345), Liu Y. et al. (2011b).
} 

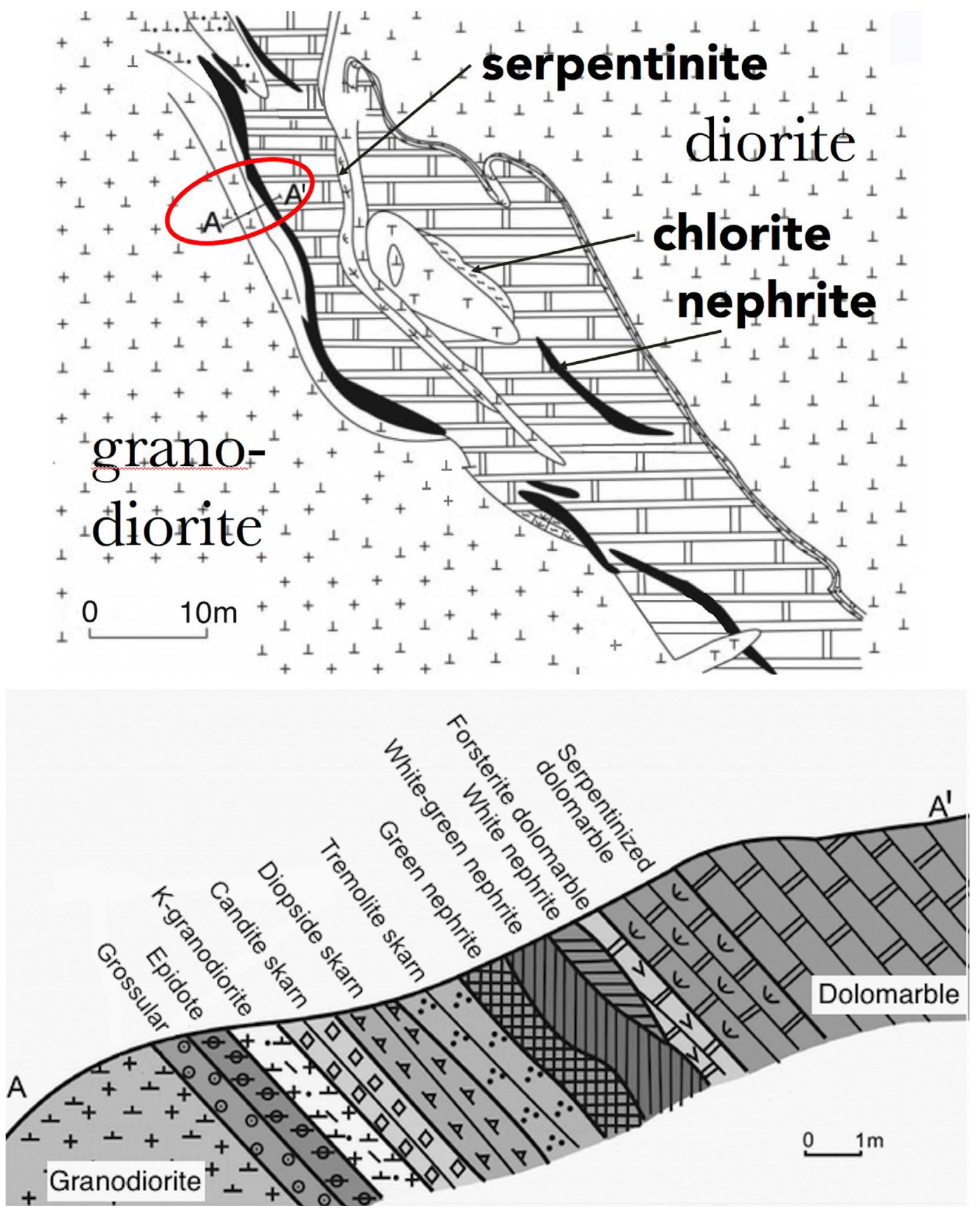

Figure 10. The Alamas ophiolite (after Zhang Q. et al. 2016). Transect A-A', circled in 10(a), is shown in section in $10(\mathrm{~b})$.

(a) dolomarble (brickwork) metamorphosed by igneous intrusion of granodiorite on the right.

(b) successive zones of metamorphism from left to right after granodiorite: contact metamorphism resulting in new minerals; then metasomatic reactions producing various skarns; then three colours of nephrites; then altered marble adjacent to the original dolomarble. 
have been processed at the mine into specific loads so that stone types and trimmings that were not of economic value would have been discarded - possibly providing a resource for future archaeological investigation. ${ }^{131}$ For example, archaeological excavation ${ }^{132}$ of a nephrite workshop and pit-mine at Mazongshan, Gansu Province, may illuminate what rocks and minerals occur together.

\section{Southern Xinjiang D-nephrites}

The main source of 'mutton fat' jade was Hetian (Hotan). This is the name of a county, and its county seat, sandwiched between the Black and White Jade rivers in the southern Tarim Basin. Together with Yutian, aka Keriya County to the east of Hetian, it names one of the three groups of primary nephrite sources in the western Kunlun mountains of southern Xinjiang Province. The word 'primary' refers to in-situ deposits rather than secondary (placer) finds in the alluvial riverbeds.

The three groups of these true jades are designated by their important town names: Shache-Yechang with four primary deposits; Hetian-Yutian (Hotan-Keriya) with 11 primary deposits, and Qiemo-Ruoqiang having three primary deposits - altogether 18 primary deposits with individual names not given here. ${ }^{133}$ Nephrites from these sources contain several accessory minerals: graphite, apatite, diopside, allanite, zircon, and rutile; and the nephrites occur in association with several other rocks and minerals: diorite, granodiorite, dolomarble, gneiss, schist, quartz, and pyrite.

Southern Xinjiang nephrites have a variety of different compositions and colours, ranging from white tremolite, to light- and dark-green nephrite, to black tremolite and black actinolite. The elements causing the black colour in the latter two nephrites are different: black tremolites contain graphite, whereas black actinolites are coloured by high iron content. ${ }^{134}$ Even 'mutton fat' nephrite composed of 99.6 per cent tremolite can incorporate biotite (black mica with iron content), whereas light-green nephrite of 93 per cent tremolite contains 1 per cent epidote inclusions acting as the colouring agent. ${ }^{135}$

The lesson from Hetian, however, is that 'tremolite' is not a synonym for 'mutton fat' white jade (though the reverse is true). ${ }^{136}$ Tremolite can occur as other colours, with increasing iron (or chromium) content to make it green, or with graphite to make it black. Nevertheless, despite these colours, the Hetian district nephrites were produced by the classic scenario described by Wen and Jing: dolomarble intruded by granite, with concomitant contact metasomatism.

${ }^{131}$ Thanks to economic geologist Brendan Caulfield for this thought.

${ }^{132}$ Wang J. (2014).

${ }^{133}$ Liu Y. et al. (2011a), Harlow et al. (2014: Figure 10-25).

${ }^{134}$ Liu Y. et al. (2011a).

${ }^{135}$ Shi Q. (1987).

${ }^{136}$ As emphasised by George Harlow. 


\section{Luanchuan D-nephrites}

Nephrites occur at Luanchan, Henan Province, in the Qinling suture zone between the North and South China Blocks. The host rock of interest here is the marble in contact with metamorphosed gabbros.

Previous studies have postulated that the nephrites were formed by metasomatism between intrusive gabbros and marbles. If this were the case, the gabbro and nephrite should be of the same date. However, a study in 2015 discovered that the gabbros are 850 million years old and they have been metamorphosed, hence the name 'metagabbros'. In contrast, the nephrites date to 360 mya, as assessed through uraniumlead isotope dating. ${ }^{137} \mathrm{~A}$ gap of 500 million years means the gabbro could not possibly have intruded the later marbles.

It also became clear that the nephrite deposits are located along NW/SE-trending fault lines. Although the researchers pondered the possible presence of some granitic fluids, they concluded that the nephrites most likely formed by circulation of crustal fluids associated with the shearing activity along these fault lines at $c a .360$ mya. In other words, these tremolites are not a product of contact metasomatism from an igneous intrusion but were produced by fault movement involving fluids, a form of cataclastic metamorphism accompanied by metasomatism.

\section{Wenchuan D-nephrites}

Sources in Wenchuan County in Sichuan Province have very high ratios of manganese to iron $(\mathrm{Mn} / \mathrm{Fe})$. Factor analysis has shown that these values distinguish nephrites from this source from other D-nephrites in China, as well as from S-nephrites from China and abroad, as seen in Figure 3: nos. 31, 32. The source area lies on the western side of the Longmenshan thrust fault - a fossil subduction zone that marks the collision zone between the Tibetan Plateau and the Sichuan Basin (responsible for the 2008 earthquake there). ${ }^{138}$

\section{Nephrite from serpentinite: S-nephrites (Ns)}

\section{Contact between serpentinite and various rocks ${ }^{139}$}

Although nephrites from serpentinite occur in comparable geological environments throughout the world, the specific combinations of rocks are varied and the processes of nephrite derivation are also varied. The geological environment is within ophiolite belts. S-nephrite forms via contact metasomatism between the host rock of serpentinite

\footnotetext{
${ }^{137}$ Ling et al. (2015).

${ }^{138}$ Tectonics Observatory (2008).

${ }^{139}$ Summarised from Harlow et al. (2014: 347-57).
} 
(or serpentinising peridotite) and a variety of rocks with high silica content: plagiogranite, albitite, metagabbro, muscovite-quartz schist, graywacke, shale, phyllite, or chert. ${ }^{140}$ Interestingly, Z. Zhang et al. specifically list 'marble or dolomite' as a contact rock for the host-rock serpentinite in making S-nephrites. ${ }^{141}$

The formation of S-nephrite is not yet well understood, with several models and experiments being replicated. However, Harlow et al. conclude that S-nephrite forms through replacement of serpentine minerals, drawing calcium from silicic rocks. ${ }^{142}$ Zoned progression is typical of the metasomatism, with nephrite usually forming closest to the serpentine host-rock; other zones may contain diopsidite, epidotite, talc, chloritite, albitite, zoisitite, and rodingite ${ }^{143}$ _ depending on the contact rock and other conditions. ${ }^{144}$ A model for metasomatic zoned alteration between serpentinite and a granite is shown in Figure 11.

\section{Qinghai D-nephrites and S-nephrites}

Qinghai nephrite, also known as Kunlun jade, is obtained from near Golmud City in southern Haixi Prefecture, Qinghai Province. Eight named localities are known, and three mines are in operation. More than 30 nephrite orebodies are being exploitedall primary, not alluvial, deposits. ${ }^{145}$ This is an interesting case because both D-nephrites and S-nephrites have been discovered here.

Early work showed that Qinghai nephrite contains wollastonite $\left(\mathrm{CaSiO}_{3}\right)$ distinct from Hetian nephrite. ${ }^{146}$ Work in 2016 showed that all the nephrite from around Golmud contains tremolite. However, among these tremolites, both D-nephrite and S-nephrite were identified - indicating the presence of both host rocks, dolomarble and serpentinite, in the same tectonic setting. ${ }^{147}$ This would be consistent with the presence of ophiolites including limestone caps, though no mention is made of ophiolites in Li et al.'s report.

Interestingly, among S-nephrites from serpentinite, two different original rock types could be identified through differences in their rare earth element (REE) content: serpentinite based on dunite (one of the peridotite derivatives) and serpentinite based on gabbro. This level of identification makes it clear that jade sourcing can

\footnotetext{
${ }^{140}$ Harlow et al. (2014: Table 10-5).

${ }^{141}$ Zhang Z. W. et al. (2012: 367).

${ }^{142}$ Harlow et al. (2014: 355-6).

${ }^{143}$ The rock rodingite has a varied composition but may include the minerals grossular, hydrogrossular (hibschite), chlorite, diopside, vesuvianite (idocrase), zircon, albite, hornblende, garnet, epidote, zoisite, quartz, prehnite, clinozoisite, and biotite.

${ }^{144}$ Harlow et al. (2014: Table 10-5).

${ }^{145} \mathrm{Yu}$ et al. (2016).

${ }^{146} \mathrm{Li}$ R. et al. (2004).

${ }^{147} \mathrm{Yu}$ et al. (2016).
} 


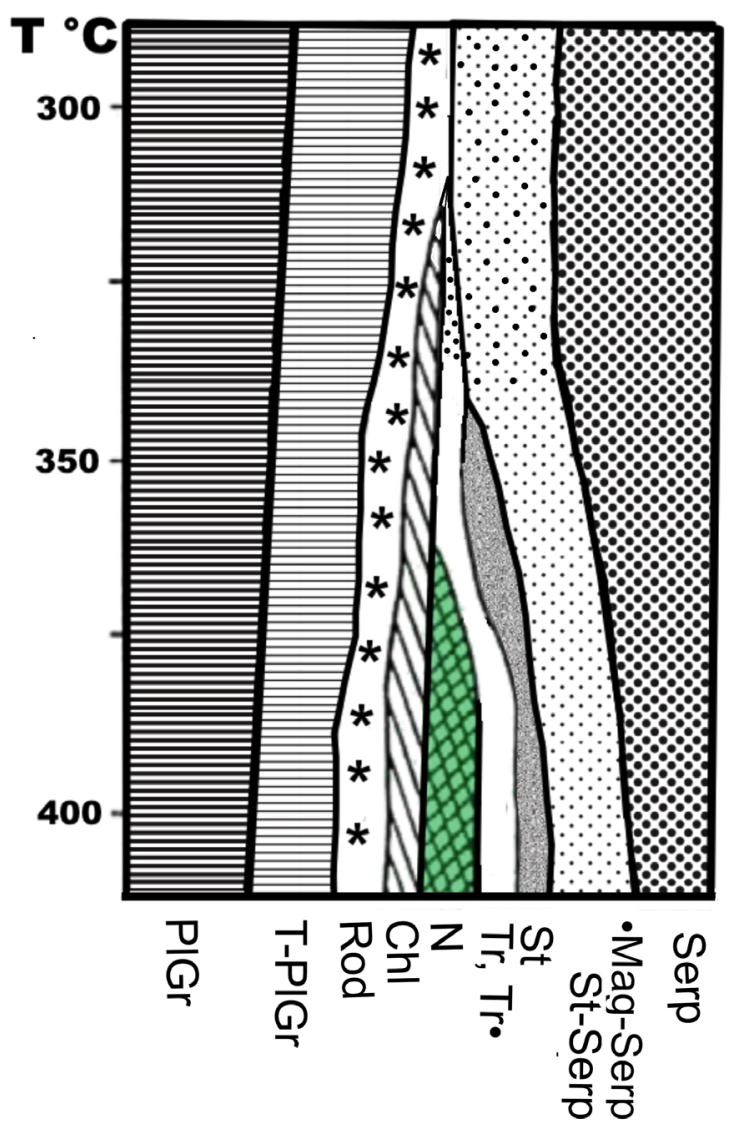

Figure 11. Experimental model by Karpov and colleagues of metasomatic contact between serpentinite and a granite, causing zoned alteration, at $\mathrm{P} / \mathrm{T}$ of $200 \mathrm{MPa}$ and $280-425^{\circ} \mathrm{C}$; S-nephrite appears in the centre (modified after Harlow et al. 2014: Figure 10-30b). Zonation from the left-PlGr: plagiogranite, T-PlGr: tremolitized plagiogranite, Rod: rodingite, Chl: chloritite, $\mathrm{N}$ : nephrite from serpentinite, $\mathrm{Tr}$ : tremolitite, $\operatorname{Tr} \bullet$ : tremolite- magnetite rock, St: steatite, $\bullet$ Mt-Serp: magnetite-serpentinite at top, St-Serp: steatized serpentinite at botttom, Serp: serpentinite.

distinguish between very localised products, but the numerical possibilities here are enormous among 30 known orebodies.

Another interesting lesson from Qinghai is that serpentinite and dolomarble can exist in the same tectonic setting: that is, within an ophiolite belt or orogenic zone. This arises from dolomite layers in continental shelf areas caught up in the emplacement of an ophiolite slice in the continental edge. The juxtapositioning not only facilitates the formation of both S- and D-nephrites, but also it brings their associated minerals into proximity. 


\section{Manas jades in the northwest}

The other important source of jades in Xinjiang Province is located north of the Tarim Basin in a completely different orogenic zone. This is the Palaeo-Asian Ocean region that has given rise to the CAOB (Central Asian Orogenic Belt). This source has only been exploited since the early 20th century. S-nephrites from Manas formed in serpentinite derived from ultramafic igneous peridotites, and they therefore attest to the presence of ophiolites in this region. The essential mineral was named as tremolite but with high amounts of iron due to its ultramafic derivation. ${ }^{148}$ Chemical analysis showed that the 'tremolite' contents range from 80 to 95 per cent, thus crossing the tremolite/actinolite border; minor minerals include diopside, chlorite, garnet, and chrome spinel. ${ }^{149}$

\section{Mineral associations}

\section{Nephrites and their associated minerals}

It can be seen from the above descriptions that the formation of nephrite is associated with the formation of other metamorphic rocks and minerals, whether they precede nephrite (i.e., marble or serpentine) or are concurrent with its formation. Concurrent minerals may exist in three forms:

- as minor minerals in jade rocks, making up the last 10 per cent of the nephrite. These minerals can be microscopic - occurring as tiny crystals of a few tens of microns - up to several millimetres in size; ${ }^{150}$

- as major minerals in zoned bands, such as chlorite in the chloritite band and talc in the steatite band in Figure 11;

- chlorite, calcite, quartz and talc, serpentine, etc. as mineral deposits in their own right.

The sharing of elements and minerals between the host rock and formative zonation can possibly be used to match non-nephrite objects made of mineable minerals with nephrite sources. It is logical that such minerals and rocks would be mined together and possibly distributed together for artefact fabrication. Under some conditions, the resulting objects might all be kept together in usage patterns, or they could be divided by value and thus inform us on status and ranking within a society. In studying such phenomena in the archaeological record, it is important to monitor all types of ornamental stones, not just those highly valued nephrites that approach the ideal tremolite composition.

\footnotetext{
${ }^{148}$ Han \& Hong (2009) and Tang Y. et al. (2002). It was early on referred to as Manas jasper (Zou et al. 2002).

${ }^{149}$ Shi Q. (1987).

${ }^{150}$ Iizuka (2012).
} 
Many minerals and rocks are common to both nephrite ore deposits and assemblages of false jades, confirming that the latter may have an important role to play in determining nephrite sources, and artefact production and consumption patterns.

Two areas where nephrites occur in association with other types of potentially ornamental rocks are discussed below.

\section{Jades from the Qinling orogenic zone}

As mentioned above, some of the major types of 'jades' used in China throughout the centuries were not and are not 'true jades' but other rocks and minerals. However, some of these non-nephrite jades were subject to the same formation processes or occur in the same tectonic settings as nephrites. Here, Dushan jade (a non-nephrite) and Lantian jade (both nephrite and non-nephrite) will be discussed.

Dushan jade, from Nanyang City in Henan Province, is a zoisitised plagioclase formed through many metamorphic events within the Qinling orogenic belt. ${ }^{151}$ It is an aggregate of three minerals: plagioclase, zoisite, and varieties of hornblende. This jade formed in a fault zone under extreme tectonic stress-where cataclastic metamorphism involved the grinding of rocks, leading to the generation of fluids and recrystallisation of minerals. ${ }^{152}$ Metasomatic textures have been reported. Several trace-elements, especially chromium, produce Dushan jade of different colours, resulting from several different episodes of metamorphic reaction.

Among the accessory minerals of Dushan jade are tremolite and actinolite. At least some of this tremolite is known to be felted, but the issue here is whether this mineral can occur in large enough masses to be mineable as nephrite rather than just an accessory to zoisitised plagioclase. The answer to this could lie in the tectonic setting of Luanchuan nephrite, which occurs slightly northwest of Dushan in the northern Qinling orogenic zone. We saw above that Luanchuan nephrite was likely produced within fault zones under tectonic stress, similar to Dushan jade. However, the presence in that region of dolomarble and meta-gabbro provided the proper constituents for the formation of 'true jade'.

Further west, the Qinling orogenic zone runs south of Xi'an City, Shaanxi Province, where the Chang'an capitals of the Han and Tang Dynasties were located. The official jade mine of the Tang Dynasty was situated at Mt. Yu (Jade Mountain, now called Mt. Wangshun) in the Qinling Mountains about 30-35 km southeast of Chang'an. ${ }^{153}$ Lantian jade was exploited through several early dynasties into the 13th

\footnotetext{
${ }^{151}$ Zhang G. et al. (1989), Hacker et al. (2004).

${ }^{152}$ Xiao Q. et al. (2009).

${ }^{153}$ Anon (n.d.a.); the geographical source of Lantian jades is said in Shi Q. (1987) to be 玉泉山 (Mt. Yuquan); there is a Mt. Quan (泉山) located north of Xi'an near Yan'an City, but玉泉山is likely a mistake (quan for chuan) or conflation of玉山 (Yushan) and玉川淟 (Yuchuanzhen, Yu River Township) near
} 
century, and then it disappeared. New sources were discovered in $1978,{ }^{154}$ but it is controversial whether the new jade is the same material as archaic Lantian jade (lantianyu). ${ }^{155}$

Lantian jades, found in Lantian County, may have formed by the same types of metamorphic process. Over 100 ophiolites are known from the Qinling orogenic zone, so it is possible that contact metasomatism was responsible. Some archaic Lantian jades are identified as nephrite; white and whitish-yellow tremolite was highly prized, but a blue variety was exceptionally treasured. ${ }^{156}$ The exact source of these nephrites is unknown and may have been exhausted early on. Almost all modern Lantian jades are not nephrite.

Mineralogical analysis identified several different types of modern Lantian jade: ${ }^{157}$ two types based on serpentine minerals, ${ }^{158}$ and a separate type of serpentinised marble. They all have similar accessory minerals (calcite, dolomite, talc, augite, chlorite, zircon, and tremolite), but the trace elements, manganese, zirconium, and zinc, occur at higher levels in the marble, further distinguishing the two rocks.

Thus, the Qinling orogenic zone has given rise to nephrite as well as several kinds of non-nephrite jades: serpentinite (antigorite, lizardite), zoisitised plagioclase, and serpentinised marble.

\section{Jades from the Jiao-Liao-He belt}

To the northeast, the Xiuyan Manchu Autonomous District in Liaoning Province now supplies more than 60 per cent of today's serpentinite jade for the domestic market - in addition to overseas sales. Three colours are prominent, based on varieties of the three main serpentine minerals: lizardite is green, antigorite is white, and yellow is formed from lizardite, antigorite, and chrysotile. ${ }^{159}$

Several jades are known from Xiuyan: plain serpentinite jade is known as 'new mountain jade' or xiuyu. Such serpentinite invaded by iron oxides is called flower jade, or hwayu. Jiacui is a hemi-jade: a mixture of tremolite and serpentine. In addition, there are two types of nephrite: Longtan moyu, a black tremolite-actinolite containing

Mt. Yu 玉山 in Lantian County southeast of Xi'an. The Shi Q. (1987) reference is probably responsible for Beijing Tourism stating that Lantian jade comes from north of Xi'an, while most cite Yuchuan 玉川, Lantian County in the southeast as the source.

${ }^{154}$ Bijing Toruism (2014), Anon. (n.d.a).

${ }^{155}$ Wang Y. et al. (2012).

${ }^{156}$ Mindat (n.d.), citing Zhang J. \& Luo (2002).

${ }^{157}$ Wang Y. et al. (2012), Zhang J. \& Luo (2002), Xia \& Luo (2002).

${ }^{158}$ One, ophicalcite, is serpentinite massively intruded by calcite veins (Wen \& Jing 1996, Strekeisen 2007-17).

${ }^{159}$ Liu J. \& Cui (2012). 
calcite and olivine. And laoyu 'old jade', which is a white tremolite. ${ }^{160}$ A serpentinised marble is another product containing 10-65 per cent serpentine minerals. ${ }^{161}$ Tremolite jade has also been discovered in nearby Kuandian. These are the two sources in Liaoning, and it should now be clear that none of these product names directly reveals their mineral contents.

New research has provided a geological setting for the formation of these jades: the Jiao-Liao-He belt, which stretches across the Liaodong Peninsula into the Shandong Peninsula, previously interpreted as a rift zone, has been reinterpreted as an arc-continent collision zone. ${ }^{162}$ It may thus be part of the Nipponides orogenic belt that extends from Sakhalin Island in the north through Japan and Cathaysia perhaps as far as Hainan Island. ${ }^{163}$ This would potentially provide the limestone and igneous rocks necessary for host rock and nephrite formation and account for the abundance of serpentinite in the region. It is possible, judging from map locations, that Laiyang jade from Yantai County in Shangdong ${ }^{164}$ and the newly discovered Pizhou City 'Lantian jade' also formed in the Jiao-Liao-He belt as it dives deep into Jiangsu Province. Again, the juxtapositioning of the igneous and limestone rocks in specific tectonic settings, as seen in southeastern China, ${ }^{165}$ is the clue needed for mining these valued ornamental rocks: more serpentinite than nephrite, but the potential for both.

\section{Nephrite analyses}

Previous archaeological research on sourcing Chinese D-nephrite artefacts ground to a halt in the 1990s for several reasons. ${ }^{166}$ First, the composition of tremolite objects was assessed through destructive whole-rock chemical analysis; there was not enough variation to distinguish between the nephrites (because they all conformed to the major and minor elements in the 'ideal' tremolite composition, as seen in Table 3). Second, there were few if any analyses of raw D-nephrites from geological sources with which to compare minor and trace elements.

Analyses of archaeological jades in China picked up again in the early 2000s, after non-destructive PIXE analyses became available, though this technique did not become popular until 2010. ${ }^{167}$ PIXE provides compositional data for individual points

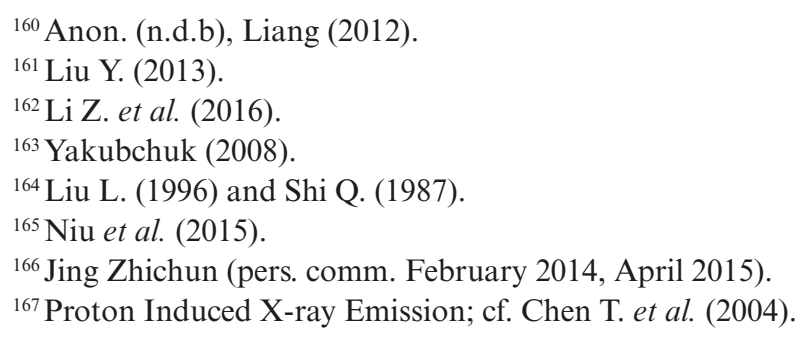


on samples; with the recognition that composition can vary through space in a zoned deposit, several spot analyses on individual samples are required to understand the structure of sample composition. This is particularly useful if samples cross the tremolite-actinolite border, or to elucidate colour gradations, as in Alamas nephrite or post-depositional alteration. In this respect, hemi-jades-where the content of tremolite-actinolite or jadeite drops below the percentage used to define nephrite and jadeitite rocks - might be most useful. The associated minerals in such compositions are clearly associated with the true jade minerals and indicate conditions of formation that perhaps can be traced to the source.

More chemical data are now available on nephrite source materials than on nephrite artefacts. Reports must be handled with care, however, because terminology is constantly a source of misunderstanding. For example, one report discusses 'serpentine jade' clearly divided into Type I from carbonate and Type II formed from metasomatism of ultrabasics. ${ }^{168}$ These are not to be confused with $\mathrm{dN}$ and $\mathrm{sN}$ but represent stage (3) process in Figure 5 identifying serpentine minerals from different parent rocks. The characters for another green stone, 'jasper' (biyu 碧玉), can also be used to mean 'green jade', usually sN. Another problem is the naming of minerals in compositional analyses: it is not always clear whether tremolite and/or actinolite have the felting necessary for the rock to be considered as nephrite.

For the few artefact tests that have been done, analysis generally aims at identifying the mineral or rock, particularly to distinguish nephrites from non-nephrites. Little work has been done on the distinctive compositions of either of these groups of archaeological artefacts. Nevertheless, some unique characteristics have been discovered in nephrite source materials.

Hydrogen/oxygen isotope ratios $\partial \mathrm{D}(\%) / \partial \mathrm{O}^{18}(\% 0)$ in Alamas nephrites 'clearly indicate differences in formation temperature, isotope compositions of the source rock, and/or fluid/rock ratio during nephrite formation' compared with other D-nephrites around the world. ${ }^{169}$ Local geological conditions have contributed to other distinctive varieties. The high strontium-Sr content of Xiaomeiling nephrite is noted as distinguishing it from all others, and it also has high potassium-K and sodium-Na contents; the strontium is derived from the surrounding country rock, as indicated by the presence of a deposit of celestine $\left(\mathrm{SrSO}_{4}\right)$ about $60 \mathrm{~km}$ from Xiaomeiling at Aijing Hill in Lishui, Jiangsu Province. ${ }^{170}$ Similarly, Wenchuan nephrite has high manganese/iron ratio $(\mathrm{Mn} / \mathrm{Fe})$ due to a deposit of the polianite variety of

\footnotetext{
${ }^{168}$ Chen Q. et al. (2014).

${ }^{169}$ Liu Y. et al. (2011b: 450), and Figure 8.

${ }^{170}$ Zhang Z. W. et al. (2012).
} 
pyrolusite $\left(\mathrm{MnO}_{2}\right)$ about $80 \mathrm{~km}$ away at Heishui, Sichuan. ${ }^{111}$ Qinghai nephrites contain wollastonite $\left(\mathrm{CaSiO}_{3}\right)$, distinguishing them from Hetian nephrites. ${ }^{172}$

Artefacts made from nephrite from these sources should exhibit similar chemical constitutions. Jades from the Jinsha Culture in Sichuan have characteristic rare earth element contents (REE) that conform to the Longxi Township nephrite source, in Wenchuan County. ${ }^{173}$ However, analysis of jade objects excavated from Liangzhu Culture graves proved them not to be made from Xiaomeiling nephrite, despite initial assumptions that they were. ${ }^{174}$ The Liangzhu artefacts did not have the high strontium levels of the Xiaomeiling source material. Longshan jades have high $\mathrm{Mn} / \mathrm{Fe}$ ratios, but they were not at that time attributed to the Wenchuan source. ${ }^{175}$ An outstanding characteristic of Liangzhu jades instead is their retention of sedimentary structures from the original limestone. ${ }^{176}$

There is also growing use of absolute dating of nephrites and nephrite source materials to distinguish products and processes. Using argon-isotope dating, Xiaomeiling nephrites have been dated to $c a .120$ mya, compared to nephrites from Qiemo at 277.3 mya. ${ }^{177}$ Testing of Early Neolithic artefacts from the nearby archaeological site of Lingjiatan produced estimated ages of 40-120 mya (based on several assumptions), making it more likely they were from the Xiaomeiling deposit (but strontium levels were not assessed). Comparative dating of the titanite formed simultaneously within the tremolite at Luanchuan, using SIMS U-Pb dating and U-Th- $\mathrm{Pb}$ dating of meta-gabbro, showed that the tremolite is 500 million years younger than the meta-gabbros. ${ }^{178}$ Thus, nephrites could not have formed by contact metasomatism with gabbro.

\footnotetext{
${ }^{171}$ Siqin et al. (2012), Zhang Z. W. et al. (2012).

${ }^{172}$ Li R. et al. (2004).

${ }^{173}$ Xiang et al. (2008).

${ }^{174}$ Gan et al. (2010), Zhang Z. W. et al. (2011, 2012).

${ }^{175}$ Douglas (2005: 208).

${ }^{176}$ Tsien et al. (1996).

${ }^{177}$ Chou et al. (2009).

${ }^{178}$ Ling et al. (2015).
} 


\section{CONCLUSIONS}

Much of this paper has been devoted to definition of terms and explanations of geological settings and processes involving nephrite and jadeitite formation. At a minimum, we should bow to geological practice and correctly refer to nephrite and jadeitite rocks, while saving specific mineral names (tremolite, actinolite, and jadeite) for the mineral constituents of those rocks. Furthermore, we must never assume that a 'jade' object is made of either nephrite or jadeitite without examination. Many other rocks and minerals have been used, past and present, as ornamental stones. Walker gives a good review of jade simulants, their various 'jade' names, and how to distinguish them from true jades. ${ }^{179}$ Identifying simulants and false jades can protect the wallet, but the information the latter hold for archaeological studies should not be ignored.

One terminological problem remains: that is the close phrasing of 'serpentine jade' and 'nephrite from serpentine'. These two should not be confused. Nephrite formed in serpentinite (S-nephrite) is most often actinolite, a true jade mineral, while serpentine or serpentinite 'jade' is comprised of one or more of the serpentine minerals.

The potential occurrence of ophiolitic or mélange serpentinite across the landscape provides a ready source for its use in ornamental-object production, as in Soochow (bowenite), Lantian (antigorite, lizardite), and Xiuyan (antigorite, lizardite) jades. Identification of these products - serpentinite and nephrite - as artefacts may inform on source regions. Xiuyan is a particularly difficult source, as the name is applied to both D-nephrite and serpentine jade; the former is called 'old jade' laoyu - found in archaeological sites-while the latter supplies most of the serpentinite false-jade market in China today.

Among the D-nephrites (from dolomarble), white tremolite objects have in the past been valued by archaeologists more highly than other colours. The past analytical concentration on white tremolites to the exclusion of other colours stalled research efforts on sourcing, but today, even some Hetian nephrites are recognised to be actinolite, having darker green colour with increasing iron content. ${ }^{180}$ The identification of colour-bearing constituents of the nephrite matrix leads to better description: chromite inclusions rather than 'black spots'. Better vocabulary for describing nephrites must follow increasingly accurate description: instead of 'brown inclusions', read 'ochre to bright orange staining from iron oxidation in the weathering rinds of alluvial/eluvial nephrite boulders'. ${ }^{181}$

\footnotetext{
${ }^{179}$ Walker (1991).

${ }^{180}$ Shi M. et al. (2015).

${ }^{181}$ Harlow et al. (2014: 341).
} 
As the processes of nephrite formation and tectonic settings become clearer, the significance of many nephrite characteristics increases (especially the significance of REE contents and trace elements). Plate tectonics plays a large role in determining the nature and distribution of nephrite sources across the landscape. Jades can be dated with radiometric techniques such as argon isotope and uranium-lead isotope dating, allowing nephrite artefacts to be matched to ophiolite-belt dates and possible sources therein. As the dates of Chinese ophiolites stretch over a billion years, there is the possibility of wide divergence among them. The Shanghai Institute of Ceramics is in the process of establishing a geological database for nephrite minerals from different deposits, investigating nephrite isotopic ratios, and analysing parent rocks and their formation processes of nephrite. ${ }^{182}$

The future looks bright for jade research in China, and many results are being published in English in major scientific journals (however, be wary of machinetranslated texts). This should open a new era of investigation by archaeologists into assemblage compositions by rock and mineral type, their possible sources, patterns of raw-material procurement, artefact manufacture, distribution, and consumption. Information should be given on where the artefacts were excavated and where they are now located, along with published references. In all mineralogical and geochemical analyses of nephrite, we would hope that certain information is always provided:

1. host rock and contact rock, their ages and tectonic settings;

2. identity of essential mineral(s) (not just 'nephrite') and whether the minerals are felted or not;

3. chemical composition and spectroscopic results;

4. a statement whether the nephrite minerals are thought to be derived from dolomarble or serpentinite, and whether that serpentinite is derived in turn from dolomarble or mafic/ultramafic rocks;

5. postulation on metamorphic processes (contact metamorphism, contact metasomatism, cataclastic metamorphism): which rocks were involved and what chemical transformations took place; and

6. which rocks contributed the elements that form the minerals (e.g., iron from ultramafics).

Then we can begin to fill in the blank spaces in Table 7 and track patterns of dating, geographic locations, rock associations, and mineral assemblages. The use of rare earth elements and other trace elements in characterising sources has already produced interesting associations and identified distinguishing characteristics. Exciting, indeed!

${ }^{182}$ Siqin et al. (2014). 
Acknowledgements: It has been a pleasure to research Chinese nephrite in preparation for the Elsley Zeitlyn Lecture on Chinese Archaeology and Culture and an honour to present this material at the British Academy on 2 February 2017. I am grateful to many colleagues for their excellent publications on jade, which I have mined for their nuggets of information on nephrite formation. I have also benefitted from question and answer exchanges with George Harlow, Frank Hawthorne, Jing Zhichun, Roger Keverne, Iizuka Yoshiyuki, and Niu Yaoling, who were all generous with their time and knowledge. The text further benefits from suggestions and comments on the first draft by George Harlow, Ian Mercer, Brendan Caulfield, Pat Daly, Anka Hein, David Hughes, and Andrea Greenaker; the final draft incorporates many editorial clarifications and substantive comments from an unknown reader. I am very grateful for all this feedback but remain responsible for final wordings and any mistakes therein. Finally, I am greatly indebted to the Earth Sciences Department of Durham University for granting me remote access to the library's e-journals, without which none of this research could have been accomplished.

This paper has been in development since January 2012 and was first delivered as a powerpoint lecture at the British Academy on 2 February 2017. The video of this lecture is accessible at: https://www.britac.ac.uk/video/understanding-chinese-jadeworld-context, and at https://www.youtube.com/watch?time_continue $=1 \& \mathrm{v}=\mathrm{Y} 3 \mathrm{Du}-$ 2M2-gQ

My powerpoint presentation is very similar to one given by Trudy Kwong in May 2015 to the Hong Kong Geological Society. Hers is mounted on her ResearchGate site at https://www.researchgate.net/publication/277477321_Public_ Seminar_for_Geological_Society_of_Hong_Kong_Geological_Settings_and_ Formation_of_Jade. I did not see this until April 2017 as I was finalising this paper for submission to the Journal of the British Academy, but I was astounded to find it very similar to my own. Upon communicating with Trudy, we discovered similar interests and found that we had the same geological background and were using the same sources, i.e. Harlow and colleagues, so it is not surprising that the contents of our powerpoints resemble each other. Her main interest, however, is in jadeitite, having presented her powerpoint after visiting Myanmar.

\section{REFERENCES}

Alansari, A., Bhillisse, M. \& Maacha, L. et al. (2015), 'The Co, Ni, Cr and S Mineralisations During Serpentinization Process in the Bou Azzer Ore Deposits', Journal of Tethys, 3(3): 216-36.

Anon (2006), 'Friends of Jade Section: Appraisers Yue workers', 360doc, 21 March. http://www.360doc.com/content/311/0826/0815/6549936_143450273.shtml Anon (n.d.a), 'Lantian jade', Baike Baidu. http://baike.baidu.com/item/藍田玉/83299\#4_8 Anon (n.d.b), 'Xiuyan jade', Shared Encyclopedia. http://et97.com/view/128329.htm 
Ballirano, P., Andreozzi, G. B. \& Belardi, G. (2008), 'Crystal Chemical and Structural Characterization of Fibrous Tremolite from Susa Valley, Italy, with Comments on Potential Harmful Effects on Human Health', American Mineralogist, 93: 1349-55. https://doi.org/10.2138/am.2008.2869

Barnes, G. L. (2003), 'Origins of the Japanese Islands: The New 'Big Picture', Japan Review, 15: 3-48.

Barnes, G. L. (2008), 'The Making of the Japan Sea and the Japanese Mountains: Understanding Japan's Volcanism in Structural Context', Japan Review, 20: 3-52.

Barnes, G. L. (2015), Archaeology of East Asia: The Rise of Civilization in China, Korea, and Japan (Oxford, Oxbow Books).

Bausch, I. (2003), 'Jade, Amber, Obsidian and Serpentinite: The Social Context of Exotic Stone Exchange Networks in Central Japan During the Late Middle Jomon Period', PhD thesis, Durham University. http://etheses.dur.ac.uk/4022/

Beijing Tourism (2014), 'Classifications of Jade'. http://english.visitbeijing.com.cn/a1/a-XB3V7KB1F2BCFD62AEA4B8

Bersani, D., Andò, S. \& Scrocco, L. et al. (2014), 'Study of the Composition of Amphiboles in the Tremolite-Ferro-actinolite series by Micro-Raman and SEM-EDX', 11 th International GeoRaman Conference. http://www.hou.usra.edu/meetings/georaman2014/pdf/5063.pdf

Best, M. G. (2003), Igneous and Metamorphic Petrology (Malden, MA, Blackwell).

Blake, S. (2001), Melting the Mantle (Milton Keynes, The Open University).

Campbell, G. P., Miskelly, G. M. \& Curran, J. M. et al. (2008), 'Elemental Analysis of New Zealand Nephrite Jade (Pounamu) for Forensic Purposes', UdG Digital Repository, Universitat de Girona. dugi-doc.udg.edu

Casadio, F., Douglas, J. \& Faber, K.T. (2007), 'Noninvasive Methods for the Investigation of Ancient Chinese Jades: An Integrated Analytical Approach', Analytical and Bioanalytical Chemistry, 387: 791-801. https://doi.org/10.1007/s00216-006-0684-y

Chappell, B. W. \& White, J. R. (2001), 'Two Contrasting Granite Types: 25 Years Later', Australian Journal of Earth Sciences, 48: 489-99. https://doi.org/10.1046/j.1440-0952.2001.00882.x

Chen, Q., Wang, Y. \& Gan, F. (2014), 'The Chemical Compositions and Origin Characters of Serpentine Jade from Different Deposits (abstract)', Applied Mechanics and Materials, 624: 119-23. https://doi.org/10.4028/www.scientific.net/AMM.624.119

Chen, T.-H., Calligaro, T. \& Pagès-Camagna, S. et al. (2004), 'Investigation of Chinese Archaic Jade by PIXE and $\mu$ Raman Spectrometry', Applied Physics A: Materials Science \& Processing, 79: 177-89. https://doi.org/10.1007/s00339-004-2648-4

Cheng, H. S., Zhang, Z. Q. \& Zhang, B. et al. (2004), 'Non-destructive Analysis and Identification of Jade by PIXE', Nuclear Instruments and Methods in Physics Research B, 219-20: 30-4. https://doi.org/10.1016/j.nimb.2004.01.023

Chou, S.-J., Zhang, J.-G. \& Iizuka, Y. et al. (2009), 'Argon Isotopic Dating of Neolithic Jade Artifacts and Raw Materials from Eastern China and its Implications', Terrestrial, Atmospheric and Oceanic Sciences, 20(3): 501-9. https://doi.org/10.3319/TAO.2008.07.07.01(TT)

Deer, W. A., Howie, R. A. \& Zussman, J. (1997a), Rock-forming Minerals. Vol. 2: A: Single-chain Silicates (London, Geological Society of London).

Deer, W. A., Howie, R.A. \& Zussman, J. (1997b), Rock-forming Minerals. Vol. 2 B: Double-chain Silicates (London, Geological Society of London).

Dept of Geological Sciences, University of Texas at Austin (2009), 'Jade: Jadite, Nephrite'. http://www.geo.utexas.edu/courses/347k/redesign/gem_notes/jade/jade_main.htm.

Desautels, P. E. (1986), The Jade Kingdom (New York, Van Nostrand Reinhold).

Dewey, J. (2003), 'Ophiolites and Lost Oceans: Rifts, Ridges, Arcs, and/or Scrapings?' Geological Society of America Special Paper, 373: 153-8. https://doi.org/10.1130/0-8137-2373-6.153

Dewey, J. F. \& Casey, J. F. (2011), 'The Origin of Obducted Large-slab Ophiolite Complexes', in D. Brown \& P. D. Ryan (eds), Arc-Continent Collision, Frontiers in Earth Sciences (Berlin, Springer), 431-43. https://doi.org/10.1007/978-3-540-88558-0_15 
Douglas, J. G. (2005), 'A Review of Some Recent Research on Early Chinese Jades', in National Academy of Sciences (eds), Scientific Examination of Art: Modern Techniques in Conservation and Analysis, from the Arthur M. Sackler Colloquia of the National Academy of Sciences (Washington, DC, The National Academies Press), 206-14.

Frost, B. R. \& Frost, C. D. (2004), Essentials of Igneous and Metamorphic Petrology (Cambridge, Cambridge University Press).

$\mathrm{Fu}$, R. (2003), 'The Discovery of the Wares of Jade from Xiuyan is a Big Breakthrough in the Study of Chinese Jade Culture (abstract)', Journal of Anshan Normal University, 2003(01). http://en.cnki.com.cn/Article_en/CJFDTOTAL-ASSF200301014.htm

Gan, F., Cao, J. \& Cheng, H. et al. (2010), 'The Non-destructive Analysis of Ancient Jade Artifacts Unearthed from the Liangzhu Sites at Yuhang, Zhejiang', Science China Technological Sciences, 53(12): 3404-19. https://doi.org/10.1007/s11431-010-4167-1

Hacker, B. R., Ratschbacher, L. \& Liou, J. G. (2004), 'Subduction, Collision and Exhumation in the Ultrahigh-pressure Qinling-Dabie Orogen', in J. Malpas, D. J. N., Fletcher \& J. R. Ali (eds), Aspects of the Tectonic Evolution of China (London, The Geological Society), 158-92. https://doi.org/10.1144/GSL.SP.2004.226.01.09

Han, L. \& Hong, H.-L. (2009), 'Study on Mineral Components and Geological Background of Nephrites from Three Localities in China (abstract)', Journal of Gems \& Gemology, 2009(03). http://en.cnki.com.cn/Article_en/CJFDTotal-BSHB200903001.htm

Harlov, D. \& Austrheim, H. (eds) (2013). Metasomatism and the Chemical Transformation of Rock: The Role of Fluids in Terrestrial and Extraterrestrial Processes. Lecture Notes in Earth System Sciences (Heidelberg, Springer). https://doi.org/10.1007/978-3-642-28394-9_1

Harlow, G. E. \& Sorensen, S. S. (2005), 'Jade (Nephrite and Jadeitite) and Serpentinite', International Geology Review, 47: 113-46. https://doi.org/10.2747/0020-6814.47.2.113

Harlow, G. E., Sorensen, S. S. \& Sisson, V. B. (2007), 'Jade', in L.A. Groat (ed.), The Geology of Gem Deposits (Quebec, Mineralogical Association of Canada), 207-54.

Harlow, G. E., Summerfield, G. R. \& Davies, H. et al. (2014), 'Chapter 10: The Geology of Jade Deposits', in L. A. Groat (ed.), The Geology of Gem Deposits (Québec, Mineralogical Association of Canada), 305-74.

Harlow, G. E., Tsujimori, T. \& Sorensen, S. S. (2015), 'Jadeitites and Plate Tectonics', Annual Review of Earth and Planetary Sciences, 43: 105-38. https://doi.org/10.1146/annurev-earth-060614-105215

Hawthorne, F. C., Oberti, R. \& Harlow, G. E. et al. (2012), 'IMA Report: Nomenclature of the Amphibole Supergroup', American Mineralogist, 97: 2031-48. https://doi.org/10.2138/am.2012.4276

Hsu, T., Makepeace, K. \& Lucas, A. et al. (2015), 'The Nephrite Jade Road: Evolution of the Green Nephrite Market', Gemological Institute of America, 2015 (26 October). http://www.gia.edu/gia-news-research/nephrite-jade-road-evolution-green-nephrite-market

Hughes, R. W., Galibert, O. \& Bosshart, G. et al. (2000), 'Burmese Jade: The Inscrutable Gem', Gems \& Gemology 36(1): 2-26. http://www.ruby-sapphire.com/jade_burma_part_1.htm

Hung, H.-C., Iizuka, Y. \& Bellwood, P. (2006), 'Taiwan Jade in the Context of Southeast Asian Archaeology', in E. A. Bacus, I. Glover \& V. C. Piggott (eds), Uncovering Southeast Asia's Past: Selected Papers From the 10th International Conference of the European Association of Southeast Asian Archaeologists (Singapore, NUS Press), 203-15.

Hung, H.-C., Iizuka, Y. \& Bellwood, P. et al. (2007), 'Ancient Jades Map 3,000 Years of Prehistoric Exchange in Southeast Asia', PNAS, 104(50): 19745-50. https://doi.org/10.1073/pnas.0707304104

IMA-CNMNC (International Mineralogical Association-Commission on New Minerals, Nomenclature and Classification) (2017a), 'The New IMA List of Minerals-A Work in Progress-Updated: January 2017'. http://ima-cnmnc.nrm.se/imalist.htm [now replaced by below] 
IMA-CNMNC (International Mineralogical Association-Commission on New Minerals, Nomenclature and Classification) (2017b), 'The official IMA-CNMNC List of Mineral Names: Updated list of IMA-approved minerals (September 2017)'. http://ima-cnmnc.nrm.se/imalist.htm

Imperial College London (2013), 'Imperial College Rock Library: The Glossary'. https://wwwf.imperial.ac.uk/earthscienceandengineering/rocklibrary/glossary.php

Iizuka，Y. (2012)，“考古鉱物学：低真空走査型電子顕微鏡 (LV-SEM) による玉器の分析とその成果 [Archaeological Mineralogy: Analyses of Jade by LV-SEM and Their Results]', 日本電子ニュース [Japan Electronics News], 44: 23-39.

Iizuka, Y., Hung, H.-C. \& Bellwood, P. (2007), 'A Noninvasive Mineralogical Study of Nephrite Artifacts from the Philippines and Surroundings: The Distribution of Taiwan Nephrite and Implications for Island Southeast Asian Archaeology", in J. Douglas, P. Jett \& J. Winter (eds), Scientific Research on the Sculptural Arts of Asia (London, Archetype Publications), 12-19.

Jacobs, A. (2010), 'Jade from China's West Surpasses Gold in Value', The New York Times (Asia Pacific), 20 September.

http://www.nytimes.com/2010/09/21/world/asia/21jade.html?pagewanted=1\&_r=3\&hp

Keverne, R. (ed.) (1995), Jade (London, Lorenz Books).

Kojima, S., Hayasaka, Y. \& Hiroi, Y., et al. (2016), 'Pre-Cretaceous Accretionary Complexes', in T. Moreno, S. R.Wallis \& T. Kojima et al. (eds), The Geology of Japan (London, Geological Society of London), 61-100. https://doi.org/10.1144/GOJ.3

Kumar, S. \& Singh, R. N. (eds) (2014), Modelling of Magmatic and Allied Processes (Dordrecht, Springer). https://doi.org/10.1007/978-3-319-06471-0

Li, R., Liao, Z.-T. \& Li, Y.-J. et al. (2004), 'Wollastonite in Qinghai Nephrite Jade and its Significance (abstract)', Journal of Gems \& Gemology, 2004(01).

http://en.cnki.com.cn/Article_en/CJFDTOTAL-BSHB200401005.htm

Li, Z., Chen, B. \& Wei, C. (2016), 'Is the Paleoproterozoic Jiao-Liao-Ji Belt (North China Craton) a Rift?', International Journal of Earth Sciences, 106: 355-75.

Liang, S. (2012), 'Research and Evaluation of Xiuyu Resources in Liaoning Province (abstract)', MA thesis, Liaoning Technical University.

http://cdmd.cnki.com.cn/Article/CDMD-10147-1013138767.htm

Liang, S., Wang, Y. \& Zhai, F. (2012), 'Yingkou YuLong Jade Ore Forming Conditions and Mineralization Analysis', Advanced Materials Research, 356-60: 3020-2.

Ling, X.-X., Schmädicke, E. \& Li, Q.-L. et al. (2015), 'Age Determination of Nephrite by in-situ SIMS U-Pb Dating Syngenetic Titanite: A Case Study of the Nephrite Deposit from Luanchuan, Henan, China', Lithos, 220-3: 289-99. https://doi.org/10.1016/j.lithos.2015.02.019

Liu, G. (2004), 'Residential Burials of the Xinglongwa Culture', in H. Yang, G. Liu \& C. Tang (eds.), The Origin of Jades in East Asia: Jades of the Xinglongwa Culture (Hong Kong, Centre for Chinese Archaeology and Art, The Chinese University of Hong Kong), 36-9.

Liu, J. \& Cui, W. (2002), 'Study on Nephrite (Tremolite Jade) from Three Localities in China', Journal of Gems and Gemmology, Feb:

http://en.cnki.com.cn/Article_en/CJFDTOTAL-BSHB200202009.htm.

Liu, L. (1996), 'Mortuary Ritual and Social Hierarchy in the Longshan Culture', Early China, 21: 1-46. https://doi.org/10.1017/S0362502800003394

Liu, Y. (2013), 'Metallogenic Regularity and Prospecting Criteria of Xiuyan Jade Deposit, Liaoning Province (abstract)', MA thesis, Jilin University. http://cdmd.cnki.com.cn/Article/CDMD-10183-1014129753.htm

Liu, Y., Deng, J. \& Shi, G. et al. (2010), 'Chemical Zone of Nephrite in Alamas, Xinjiang, China (abstract)', Resource Geology, 60(3): 249-59. https://doi.org/10.1111/j.1751-3928.2010.00135.x

Liu, Y., Deng, J. \& Shi, G. et al. (2011a), 'Geochemistry and Petrogenesis of Placer Nephrite from Hetian, Xinjiang, Northwest China', Ore Geology Reviews, 41: 122-32.

https://doi.org/10.1016/j.oregeorev.2011.07.004 
Liu, Y., Deng, J. \& Shi, G. et al. (2011b), 'Geochemistry and Petrology of Nephrite from Alamas, Xinjiang, NW China', Journal of Asian Earth Sciences, 42(3): 440-51. https://doi.org/10.1016/j.jseaes.2011.05.012

Liu, Z., Gan, F. \& Cheng, H. et al. (2009), 'Mineral Structure and Nondestructive Analysis of Xiuyan Jade from Liaoning Province (abstract)', Acta Petrologica Sinica, 25(05): 1281-7.

Machel, H. G. (2004), 'Concepts and Models of Dolomitization: A Critical Reappraisal', in C. J. R. Braithwaite, G. Rizzi \& G. Darke (eds), The Geometry and Petrogenesis of Dolomite Hydcrocarbon Reservoirs (London, Geological Society of London), 7-64. https://doi.org/10.1144/GSL.SP.2004.235.01.02

Malpas, J. (1992), 'Serpentine and the Geology of Serpentinized Rocks', in B. A. Roberts \& J. Proctor (eds), The Ecology of Areas with Serpentinized Rocks: A World View (Dordrecht, Kluwer Academic), 7-30. https://doi.org/10.1007/978-94-011-3722-5_2

Middleton, A. \& Ambers, J. (2005), 'Case Study: An Analysis of Nephrite Jade Using Raman Microscopy and X-ray Fluorescence Spectroscopy', in H. G. M. Edwards \& J. M. Chalmers (eds), Raman Spectroscopy in Archaeology and Art History (London, Royal Society of Chemistry), 403-11.

Middleton, A. P. \& Freestone, I. (1995), 'The Mineralogy and Occurrence of Jade', appendix to Chinese Jade, by J. Rawson (London, British Museum Press), 413-23.

Mindat (n.d.), 'Mineralogy Database: Mineral Collecting, Localities, Mineral Photos and Data'. https://www.mindat.org/

Minoscam (Mineralogical Society of America) (2016), 'Mohs' Scale of Hardness'. http://www.minsocam.org/MSA/collectors_corner/article/mohs.htm

Moore, C. H. (1989), Carbonate Diagenesis and Porosity. (Amsterdam, Elsevier).

Nelson, S. A. (2011), 'Inosilicates (Pyroxenes and Amphiboles)', Tulane University course material, EENS2110. http://www.tulane.edu/ sanelson/eens211/inosilicates.htm

Newton, R. C. (2014), 'Book Review: Metasomatism and the Chemical Transformation of Rock', Elements, April: 155. https://doi.org/10.1016/j.biocon.2014.02.020

Nickel, E. H. \& Nichols, M. C. (1991), Mineral Reference Manual (New York, Van Nostrand Reinhold). https://doi.org/10.1007/978-1-4615-3678-9

Nickel, E. \& Nichols, M. (2004), 'Mineral Names, Redefinitions \& Discreditations Passed by the CNMMN of the IMA', Materials Data, Inc. http://www.materialsdata.com

Nickel, E. H. \& Nichols, M. C. (2009), 'IMA/CNMNC List of Mineral Names' (Livermore, CA, Materials Data Inc.); available from http://pubsites.uws.edu.au/ima-cnmnc/

Niu, Y., Liu, Y. \& Xue, Q. et al. (2015), 'Exotic Origin of the Chinese Continental Shelf: New Insights into the Tectonic Evolution of the Western Pacific and Eastern China since the Mesozoic', Science Bulletin, 60(18): 1598-616. https://doi.org/10.1007/s11434-015-0891-z

Qin, L. (2013), 'The Liangzhu Culture', in A. Underhill (ed.) A Companion to Chinese Archaeology (Oxford, Wiley-Blackwell), 574-98.

Rawson, J. (1995), Chinese Jade from the Neolithic to the Qing (London, British Museum).

Reston, T. \& Manatschal, G. (2011), 'Rifted Margins: Building Blocks of Later Collision', in D. Brown \& P. D. Ryan (eds) Arc-Continent Collision (Berlin, Springer), 3-21. https://doi.org/10.1007/978-3-540-88558-0_1

Robinson, P. T. \& Zhou, M.-F. (2007), 'The Origin and Tectonic Setting of Ophiolites in China', Journal of Asian Earth Sciences, 32: 301-7. https://doi.org/10.1016/j.jseaes.2007.11.014

Sanxingdui Museum (2006), 'Jade Ware', in The Sanxingdui Site: Mystical Mask on Ancient Shu Kingdom (Beijing, China Intercontinental), 108-23.

Sax, M., Michaelson, C. \& Meeks, N. D. (2004), 'The Identification of Carving Techniques on Chinese Jade', Journal of Archaeological Science, 31(10): 1413-28. https://doi.org/10.1016/j.jas.2004.03.007 
Sax, M., Michaelson, C. \& Meeks, N. D. (2008), 'A Methodology to Identify Techniques of Jade-carving in China: The Neolithic Period', in T. Lawton (ed.), New Frontiers in Global Archaeology (Beijing, AMS Foundation for the Arts, Sciences and Humanities), 281-95.

Shervais, J. W., Choi, S. H. \& Sharp, W. D. et al. (2011), 'Serpentinite Matrix Mélange: Implications of Mixed Provenance for Mélange Formation’, GSA Special Papers, 480: 1-30. https://doi.org/10.1130/2011.2480(01)

Shi, M., Yu, B. \& Guo, Y. et al. (2015), 'Structural and Mineralogical Characterization of Green Nephrite in Hetian, Xinjiang, China (abstract)', Key Engineering Materials, 633: 159-64. https://doi.org/10.4028/www.scientific.net/KEM.633.159

Shi, Q. (1987), 'Guanyu Woguo Gudai Yuqi Cailiao Wenti [Questions Regarding Our Country's Jade Materials]', Wenwu, 1987(4): 53-63.

Siivola, J. \& Schmid, R. (2007), '12. List of Mineral Abbreviations', British Geological Survey Papers. http://www.bgs.ac.uk/scmr/docs/papers/paper_12.pdf

Siqin, B., Qian, R. \& Zhuo, S. et al. (2012), 'Glow Discharge Mass Spectrometry Studies on Nephrite Minerals Formed by Different Metallogenic Mechanisms and Geological Environments', International Journal of Mass Spectrometry, 309(1): 206-11. https://doi.org/10.1016/j.ijms.2011.10.003

Siqin, B., Qian, R. \& Zhou, S. et al. (2014), 'Studies of Rare Earth Elements to Distinguish Nephrite Samples from Different Deposits Using Direct Current Glow Discharge Mass Spectrometry', Journal of Analytical Atomic Spectrometry, 29: 2065-71. https://doi.org/10.1039/C4JA00172A

Strekeisen, A. (2007-17), 'Alex Strekeisen: I Vetrini Della Mia Fantasia'. http://www.alexstrekeisen.it/english/index.php

Sun, C. (2005), 'Research on the Stone Cutting Technology with Ropes in Neolithic Age (abstract)', Northern Cultural Relics, 2005(03). http://d.wanfangdata.com.cn/Periodical/bfww200503001

Sweeting, M. M. (1995), Karst in China: Its Geomorphology and Environment (Heidelberg, Springer). https://doi.org/10.1007/978-3-642-79520-6

Tang, C. (2008), 'Observations on the Earliest Slit Rings in North China', in Memorial to Professor Serizawa Chosuke: Archaeology, Ethnology, History Papers (Tokyo, Rokuichi Shobo), 265-75.

Tang, Y.-L., Liu, D.-Q. \& Zhou, R.-H. (2002), 'Geological Characteristics of Manasi Green Jade in Xinjiang (abstract)', Acta Petrologica Et Mineralogica, 2002(S1).

http://en.cnki.com.cn/Article_en/CJFDTOTAL-YSKW2002S1003.htm

Tectonics Observatory (2008), 'The Science Behind China's 2008 Sichuan Earthquake', California Institute of Technology.

http://www.tectonics.caltech.edu/outreach/highlights/2008MayChinaEQ/

Tennant, W. C., Claridge, R. F. C \& McCammon C. A. et al. (2005), 'Structural Studies of New Zealand Pounamu Using Mössbauer Spectroscopy and Electron Paramagnetic Resonance', Journal of the Royal Society of New Zealand, 35(4): 385-98. https://doi.org/10.1080/03014223.2005.9517790

Tsien, H. H. (1996), 'Mineralogical Studies of Archaic Jades', Acta Geologica Taiwanica, 32: 5-8.

Tsien, H. H., Tan, L. P. \& Douglas, J. G. (1996), 'Geology of Tremolite Rock and Petrofabrics of Archaic Chinese Yu', Acta Geologica Taiwanica, 32: 55-83.

Tucholke, B. E. (1998), 'Discovery of 'Megamullions' Reveals Gateways into the Ocean Crust and Upper Mantle', Oceanus Magazine, 41(1).

http://www.whoi.edu/oceanus/viewArticle.do?id=2392\&archives=truel

Walker, J. (1991), 'Jade: A Special Gemstone', in R. Keverne (ed.), Jade (London, Anness Publishing), 19-41. https://doi.org/10.1007/978-1-4615-3922-3_3

Wang, J. (trans.) (2014), 'Complete Jade Workshop Remains Found at Mazongshan Jade Mine Site in Guansu Province', Chinese Archaeology.

wahttp://www.kaogu.cn/en/Special_Events/en/Special_Events/Archaeology_Forum_2014/2015/ 0119/48984.html 
Wang, R. (2011), 'Progress Review of the Scientific Study of Chinese Ancient Jade', Archaeometry, 53(4): 674-92. https://doi.org/10.1111/j.1475-4754.2010.00564.x

Wang, R. \& Li, Y. (2011), 'Multiexcitation Raman Spectroscopy in Identification of Chinese Jade', Spectroscopy Letters: An International Journal for Rapid Communication, 44(6). http://www.tandfonline.com/doi/abs/10.1080/00387010.2011.577885

Wang, R. \& Zhang, W.-S. (2010), 'Application of Raman Spectroscopy in the Nondestructive Analyses of Ancient Chinese Jades', Journal of Raman Spectroscopy, 42 (2011.6): 1324-9.

Wang, S. (2011), 'The Spatial Distribution Characteristics, Genetic Types and Exploration History of Nephrite Deposit in China', in Proceedings of the International Symposium on Jade, September 2011 Peking University (Beijing, Peking University), 68-74.

Wang, Y. Y., Gan, F. X. \& Zhao, H. X. (2012), 'Nondestructive Analysis of Lantian Jade from Shaanxi Province, China', Applied Clay Science, 70: 79-83. https://doi.org/10.1016/j.clay.2012.09.012

Wen, G. (1989), 'Ancient Jade of China (abstract)', China Non-metallic Mining Industry Herald, March. http://en.cnki.com.cn/Article_en/CJFDTOTAL-LGFK198903003.htm

Wen, G. (1994), 'Some Features of Nephrite and its Prospecting Significance (abstract)', Institute of Geology, Chinese Academy of Geological Sciences Collected Works, 27. http://cpfd.cnki.com.cn/Article/CPFDTOTAL-ZGDJ199400003005.htm

Wen, G. \& Jing, Z. (1992), 'Chinese Neolithic Jade: A Preliminary Geoarchaeological Study', Geoarchaeology: An International Journal, 7(3): 251-75. https://doi.org/10.1002/gea.3340070304

Wen, G. \& Jing, Z. (1996), 'Mineralogical Studies of Chinese archaic jade', Acta Geologica Taiwanica, 32: $55-84$

Wittke, J. (2009), Meteorite Book, College of Engineering, Forestry, and Natural Sciences, Northern Arizona University. http://nau.edu/search.aspx?q=Meteoritebook

Xia, Z. \& Luo, B. (2002), 'Geological characteristics and genesis of the Lantian jade deposit', Shaanxi Geology 2002(2). http://www.cqvip.com/qk/91282b/200202/7144104.html

Xiang, F., Wang, C. \& Jiang, Z. et al. (2008), 'Rare-earth Element Characters of Jadewares of Jinsha Site in Chengdu and its Significance for Indicating Material Source (abstract)', Journal of Gems \& Gemmology, 2008(01). http://en.cnki.com.cn/Article_en/CJFDTotal-XAGX200801010.htm

Xiao, Q.-Y., Cai, K.-Q. \& Jiang, F.-J. (2009), 'Tentative Discussion on the Mineral Cataclasis Jadeforming Process of Dushan Jade in Nanyang City, Henan Province', Acta Geoscientica Sinica 30(5): 607-15.

http://www.cagsbulletin.com/dqxbcn/ch/reader/create_pdf.aspx?file_no=20090506\&year_id= 2009\&quarter_id=5\&falg=1

Xiao, Y., Niu, Y. \& Wang, K.-L., et al. (2016), 'Geochemical Behaviours of Chemical Elements During Subduction-zone Metamorphism and Geodynamic Significance', International Geology Review, 58(10): 1253-77. https://doi.org/10.1080/00206814.2016.1147987

Yakubchuk, A. (2008), 'Re-deciphering the Tectonic Jigsaw puzzle of Northern Eurasia', Journal of Asian Earth Sciences, 32: 82-101. https://doi.org/10.1016/j.jseaes.2007.10.009

Yu, H., Wang, R. \& Guo, J. et al. (2016), 'Study of the Minerogenetic Mechanism and Origin of Qinghai Nephrite from Golmud, Qinghai, Northwest China', Science China Earth Sciences, 59(8): 1597-609. https://doi.org/10.1007/s11430-015-0231-8

Yuan, S., Pan, G. \& Wang, L. (2009), 'Accretionary Orogenesis in the Active Continental Margins', Earth Science Frontiers, 16(3): 31-48. https://doi.org/10.1016/S1872-5791(08)60095-0

Zhang, G., Yu, Z. \& Sun, Y. et al. (1989), 'The Major Suture Zone of the Qinling Orogenic Belt', Journal of Southeast Asian Earth Sciences, 3(1/4): 63-76.

Zhang, J. \& Luo, B. (2002). 'Geology and Genesis of Jade in Yuchuan of Lantian County, Shaanxi Province", Geology of Shaanxi 20(02): 75-80.

Zhang, J., Li, Z. \& Wang, X. (1989), 'Mineralogical Studies of Jades from Dushan, Nanyang', Acta Petrologica et Mineralogica, 8(1): 53-65. 
Zhang, Q., Wang, C. Y. \& Liu, D. et al. (2007), 'A Brief Review of Ophiolites in China', Journal of Asian Earth Sciences, 32(2008): 308-24.

Zhang, Q., Liu, Y. \& Huang, H. et al. (2016), 'Petrogenesis and Tectonic Implications of the High-K Alamas Calc-Alkaline Granitoids at the Northwestern Margin of the Tibetan Plateau: Geochemical and Sr-Nd-Hf-O Isotope Constraints', Journal of Asian Earth Sciences, 127: 137-51. https://doi.org/10.1016/j.jseaes.2016.05.026

Zhang, Z. H. M., Liou, J. G. \& Coleman R. G. (1984), 'An Outline of the Plate Tectonics of China', Geological Society of America Bulletin, 95: 292-312. https://doi.org/10.1130/0016-7606(1984)95<295:AOOTPT>2.0.CO;2

Zhang, Z. W., Gan, F. X. \& Cheng, H. S. (2010), 'Chemical Composition Characteristic of Nephrite Formed by Different Metallogenic Mechanisms and Geological Environments (abstract)', Acta Mineralogica Sinica, 2010(3): 367-72.

Zhang, Z. W., Gan, F. X. \& Cheng, H. S. (2011), 'PIXE Analysis of Nephrite Minerals from Different Deposits', Nuclear Instruments and Methods in Physics Research B, 269: 460-5. https://doi.org/10.1016/j.nimb.2010.12.038

Zhang, Z. W., Xu, Y. C. \& Cheng, H. S. et al. (2012), 'Comparison of Trace Elements Analysis of Nephrite Samples from Different Deposits by PIXE and ICP-AES', X-Ray Spectrometry, 41(6): 367-70. https://doi.org/10.1002/xrs.2413

Zou, T.-R., Guo, L.-H. \& Li, W.-H. et al. (2002), 'A Study on Raman Spectra of Hetian Jade, Manasi Green Jade and Xiuyan Old Jade (abstract)', Acta Petrologica Et Mineralogica, S1.

$\mathrm{http}: / / 218.28 .134 .83 / \mathrm{KCMS} /$ detail/detail.aspx?filename=YSKW2002S1011\&dbcode= CJFQ\&dbname $=$ cjfd2002

Note on the author: Gina Barnes is Professor Emeritus of Durham University, a research affiliate of the Department of Earth Sciences at Durham, and a Professorial Research Associate at SOAS University of London. She taught East Asian Archaeology for fifteen years at Cambridge University and ten years at Durham University. Her main field is Japanese archaeology, and her book on the rise of civilisation in East Asia, recently republished as Archaeology of East Asia (Oxbow, 2015), has served as a textbook around the world for almost twenty-five years. Her professional qualifications include a BSc in Earth Sciences (geology) from the Open University. She is Founder and first President of the Society for East Asian Archaeology (SEAA). gb11@soas.ac.uk

To cite the article: Gina L. Barnes (2018), 'Understanding Chinese jade in a world context', Journal of the British Academy, 6: 1-63.

DOI https://doi.org/10.85871/jba/006.001

This article is licensed under a

Creative Commons Attribution-NonCommercial-NoDerivs 3.0 Unported License.

Journal of the British Academy (ISSN 2052-7217) is published by

The British Academy - the national academy for the humanities and social sciences.

10-11 Carlton House Terrace, London, SW1Y 5AH

www.britishacademy.ac.uk 
